\title{
WestVirginiaUniversity
}

THE RESEARCH REPOSITORY @ WVU

Graduate Theses, Dissertations, and Problem Reports

2021

\section{An Analysis of Amy Beach's Variations on Balkan Themes, Op. 60}

Yiwen Zhang

West Virginia University, yiwenzhang5@gmail.com

Follow this and additional works at: https://researchrepository.wvu.edu/etd

Part of the Music Theory Commons

\section{Recommended Citation}

Zhang, Yiwen, "An Analysis of Amy Beach's Variations on Balkan Themes, Op. 60" (2021). Graduate

Theses, Dissertations, and Problem Reports. 8122.

https://researchrepository.wvu.edu/etd/8122

This Dissertation is protected by copyright and/or related rights. It has been brought to you by the The Research Repository @ WVU with permission from the rights-holder(s). You are free to use this Dissertation in any way that is permitted by the copyright and related rights legislation that applies to your use. For other uses you must obtain permission from the rights-holder(s) directly, unless additional rights are indicated by a Creative Commons license in the record and/ or on the work itself. This Dissertation has been accepted for inclusion in WVU Graduate Theses, Dissertations, and Problem Reports collection by an authorized administrator of The Research Repository @ WVU.

For more information, please contact researchrepository@mail.wvu.edu. 
Graduate Theses, Dissertations, and Problem Reports

2021

An Analysis of Amy Beach's Variations on Balkan Themes, Op. 60

Yiwen Zhang

Follow this and additional works at: https://researchrepository.wvu.edu/etd

Part of the Music Theory Commons 
An Analysis of Amy Beach's Variations on Balkan Themes, Op. 60

Yiwen Zhang

A Doctoral Research Project submitted

to the College of Creative Arts

at West Virginia University

in partial fulfillment of the requirements for the degree of

Doctor of Musical Arts in

Piano Performance

Peter Amstutz, Chair, D.M.A

Lucy Mauro, D.M.A, Research Advisor

Kym Scott, D.M.A

Bruce Kang, Ph.D.

\author{
School of Music
}

\title{
Morgantown, West Virginia \\ 2021
}

Keywords: Amy Beach, Variations on Balkan Themes, Piano Variations, Balkan Folk Music

\section{Copyright 2021 Yiwen Zhang}




\section{ABSTRACT \\ An Analysis of Amy Beach's Variations on Balkan Themes, Op. 60 \\ Yiwen Zhang}

This research paper provides an analysis of Variations on Balkan Themes, Op. 60, one of Amy Beach's most significant solo piano works. Variations on Balkan Themes exists in four different versions: the 1906 original solo piano version, a 1936 revised solo piano version, a 1942 two-piano version and fragments of an orchestral version. This paper is focused on Beach's 1906 original solo piano work. The analysis includes descriptions of the character of each variation, the structure, the pianistic figures and selected harmonic analysis as well as information comparing the four different versions. Beach's biographical information, historical background of the work and music examples of the Balkan folksongs on which Beach based the piece are also included. 


\section{ACKOWLEDGEMENTS}

I would first like to express my sincerest thanks to my research advisor Dr. Lucy Mauro who has been a constant help to me with this research project. Her advice and guidance helped my writing to be at a higher level. In addition to this research project, Dr. Mauro is also my piano ensemble coach. It has been very fortunate for me to have known and studied with her.

I would also like to express my deep gratitude to my beloved piano teacher, Dr. Peter Amstutz. Dr. Amstutz has been a mentor, a friend and like a family member. He has been to all of my recitals and competitions throughout my doctoral years. His knowledge and passion for music will guide me even after my doctoral years.

My thanks go to Dr. Kym Scott, who provided me advice on my topic selection. In addition, Dr. Scott has supervised my graduate-assistant accompanying for three years. She is always very kind, patient and wise, and it is a joy to make music together with her.

I am also very grateful to have Dr. Bruce Kang on my committee. He is always very supportive and available.

Finally, I would like to thank all my family and friends for their encouragement and support. 


\section{TABLE OF CONTENTS}

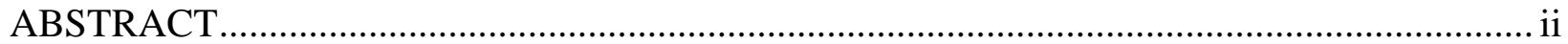

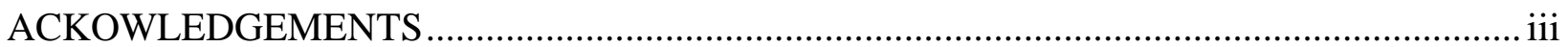

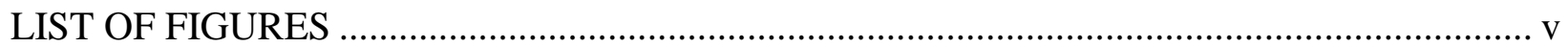

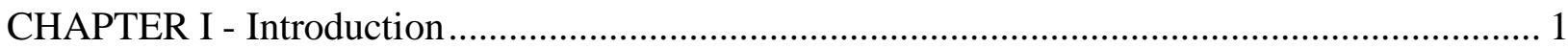

CHAPTER II - Brief Biography of Amy Beach ......................................................................... 3

CHAPTER III - Compositional Style of Amy Beach .................................................................... 14

CHAPTER IV - Historical Background of Variations on Balkan Themes.................................... 21

CHAPTER V - Analysis of Variations on Balkan Themes ……………………........................ 29

CHAPTER VI - Transcriptions of Variations on Balkan Themes ................................................ 66

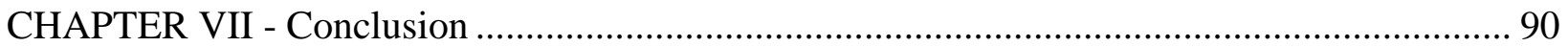

APPENDIX: SELECTED LIST OF RECORDINGS AND EDITIONS ………………............. 92

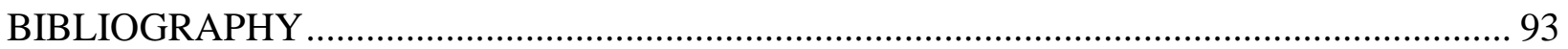




\section{LIST OF FIGURES}

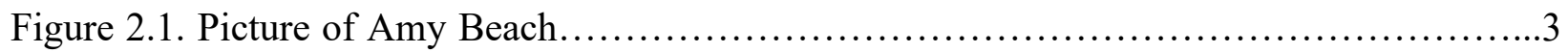

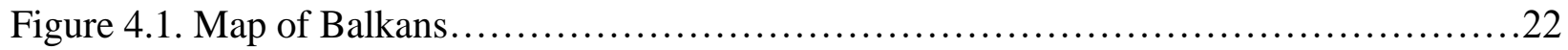

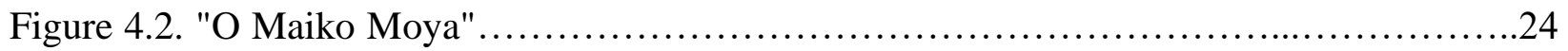

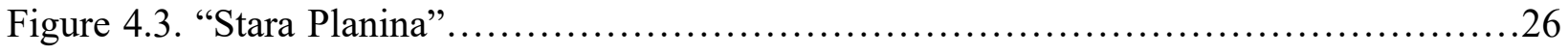

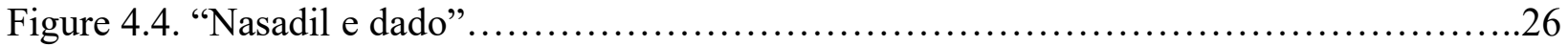

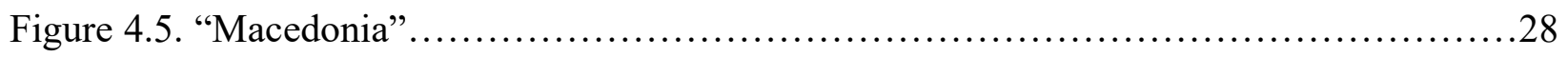

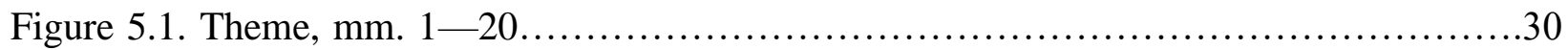

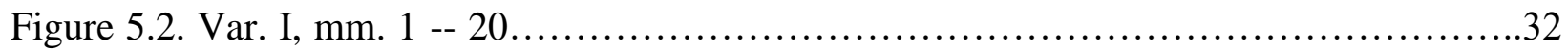

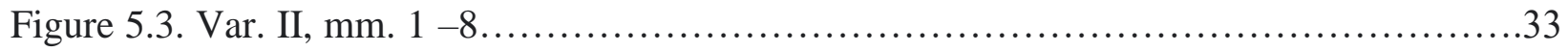

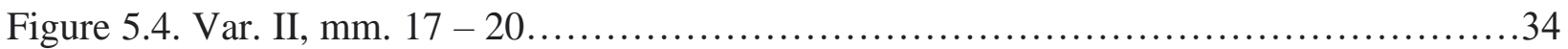

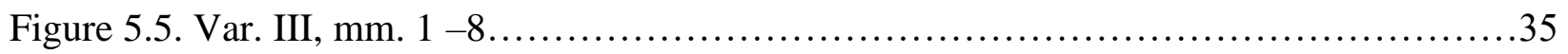

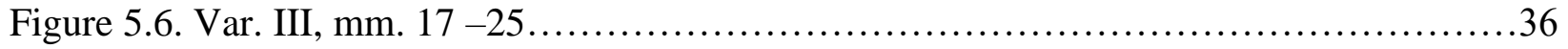

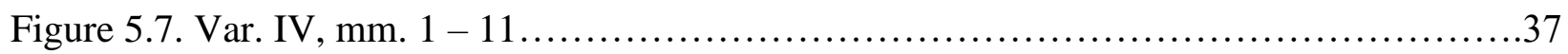

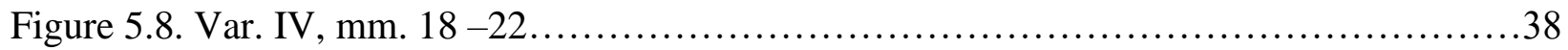

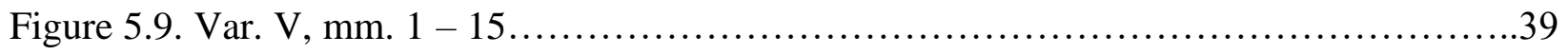

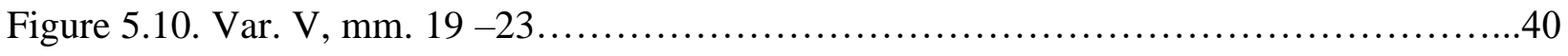

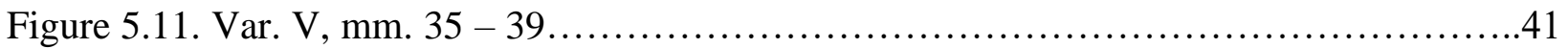

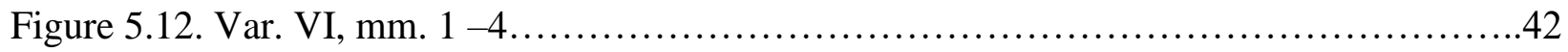

Figure 5.13. Initial Three-Note Motives of "O Maiko Moya" and "Stara Planina"...............42

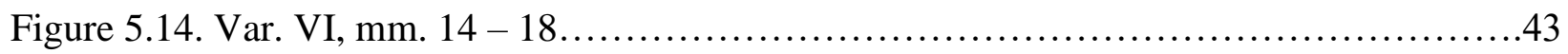

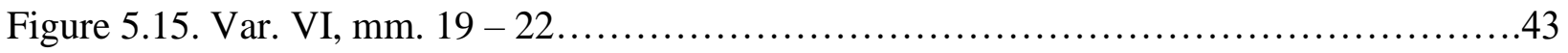

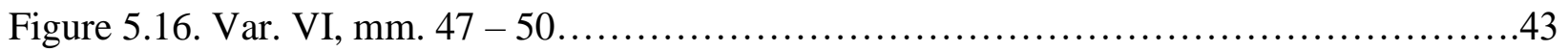




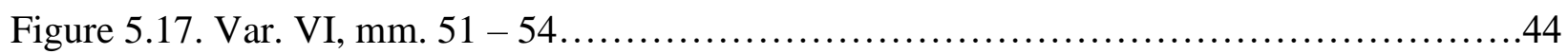

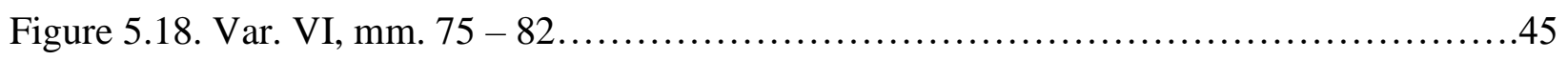

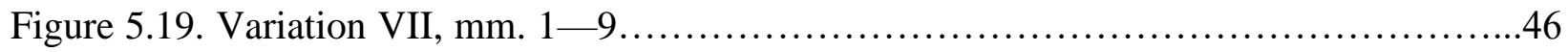

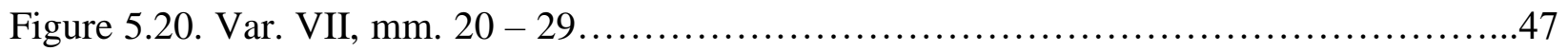

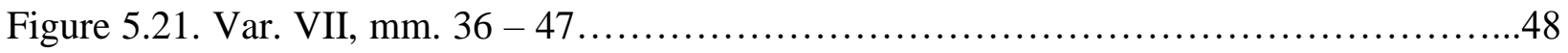

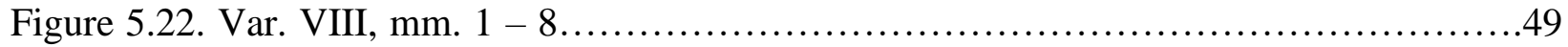

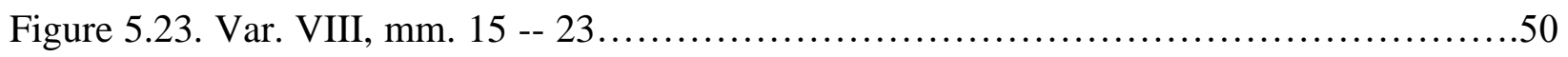

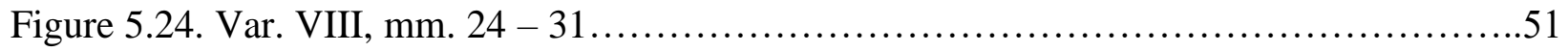

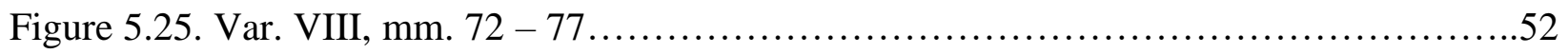

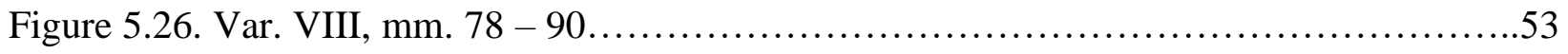

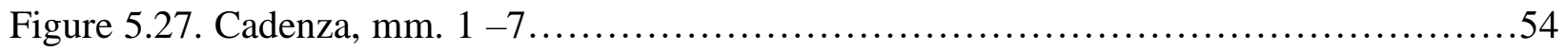

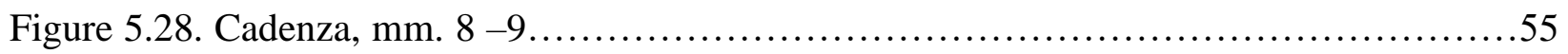

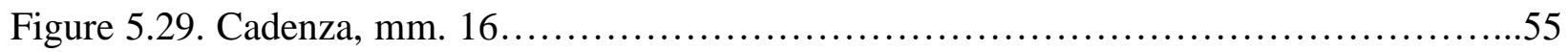

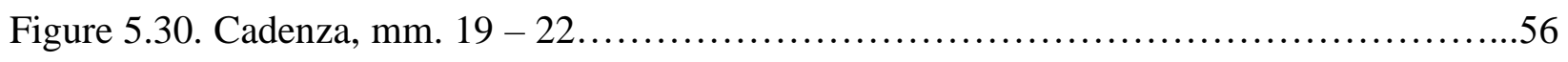

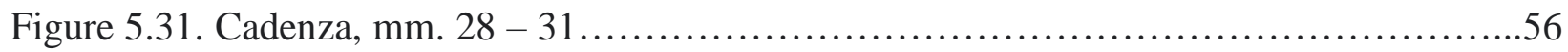

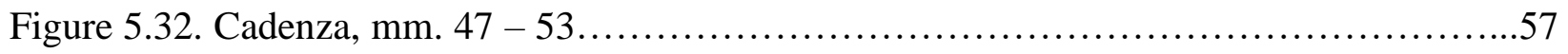

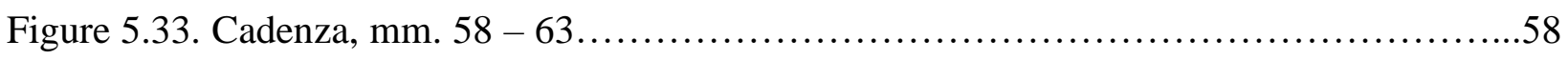

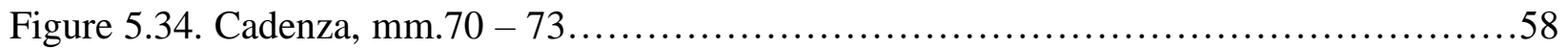

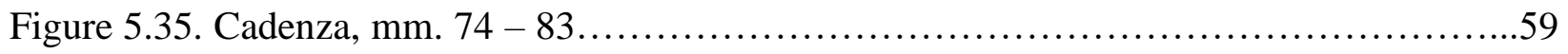

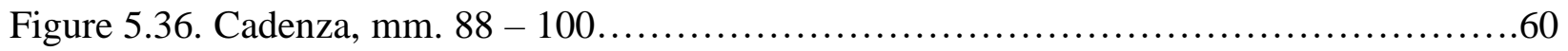

Figure 5.37. Cover Page of Manuscript................................................63

Figure 5.38. Theme from Manuscript...............................................64

Figure 5.39. Final Page of Manuscript with Completion Date...............................65 
Figure 6.1. Comparison Between Original and Revised Versions........................67

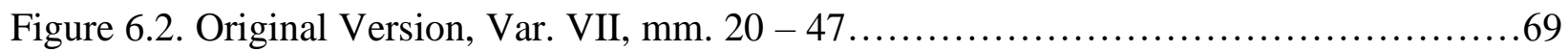

Figure 6.3. Revised Solo Piano Version, Var. IX, mm. 20 - 42..........................70

Figure 6.4. Original Version, Var. VIII, Con vigore, mm. 1 - $17 \ldots \ldots \ldots \ldots \ldots \ldots \ldots \ldots \ldots \ldots \ldots \ldots \ldots$

Figure 6.5. Revised Solo Piano Version, Var. X, Con vigore mm. 1 - 6........................72

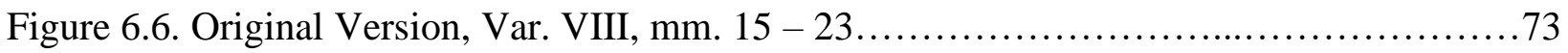

Figure 6.7. Revised Solo Piano Version, Var. X, mm. 7 - $17 \ldots \ldots \ldots \ldots \ldots \ldots \ldots \ldots \ldots \ldots \ldots . \ldots . \ldots \ldots$

Figure 6.8. Original Version, Var. VIII, Marcia funerale, mm. 24 -- 31....................74

Figure 6.9. Revised Solo Piano Version, Var. XI, Marcia funerale, mm. 1 - 20...............74

Figure 6.10. Comparison Between Revised Solo Piano and Two-Piano Versions.............76

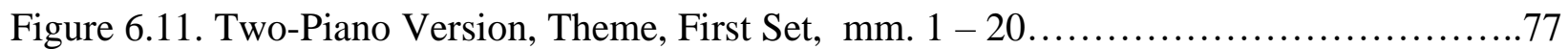

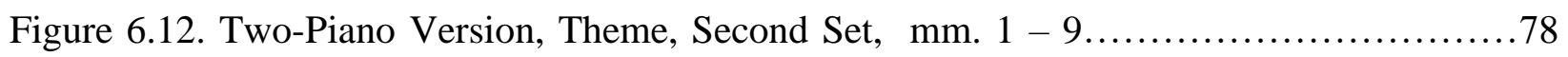

Figure 6.13. Original Solo Piano Version, Theme, mm. $1-20 \ldots \ldots \ldots \ldots \ldots \ldots \ldots \ldots \ldots \ldots \ldots$

Figure 6.14. Revised Solo Piano Version, Theme, mm. $1-20 \ldots \ldots \ldots \ldots \ldots \ldots \ldots \ldots \ldots \ldots \ldots . \ldots . \ldots . \ldots$

Figure 6.15. Two-Piano Version, Var. IV, mm. 7 -9................................... 81

Figure 6.16. Original Solo Piano Version, Var. IV, mm. 7 -9.......................... 81

Figure 6.17. Revised Solo Piano Version, Var. IV, mm. 7 -9............................. 81

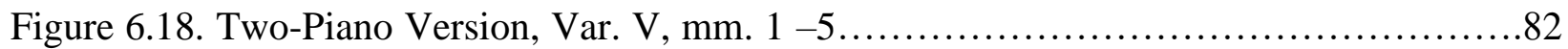

Figure 6.19. Original and Revised Solo Piano Versions, Var. V, mm. $1-3 \ldots \ldots \ldots \ldots \ldots \ldots . . . . . .82$

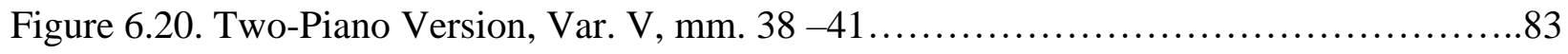

Figure 6.21. Original and Revised Solo Piano Versions, Var. V, mm. $38-39 \ldots \ldots \ldots \ldots \ldots \ldots . . . . . .83$

Figure 6.22. Two-Piano Version, Var. X, mm. $37-47 \ldots \ldots \ldots \ldots \ldots \ldots \ldots \ldots \ldots \ldots \ldots \ldots . \ldots . \ldots \ldots$

Figure 6.23. Original Solo Piano Version, Var. VII, mm. $36-47 \ldots \ldots \ldots \ldots \ldots \ldots \ldots \ldots \ldots \ldots . \ldots 5$ 
Figure 6.24. Revised Solo Piano Version, Var. IX, mm. $37-42 \ldots \ldots \ldots \ldots \ldots \ldots \ldots \ldots \ldots \ldots \ldots . \ldots . \ldots \ldots$

Figure 6.25. Two-Piano Version, Var. XI, mm. 1 - 7................................ 86

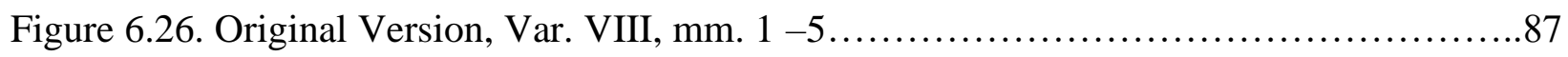

Figure 6.27. Revised Solo Piano Version, Var. X, mm. 1 -6........................... 87

Figure 6.28. Comparison Between Fragmented Orchestral and Two-Piano Versions..........88

Music excerpts of all versions of Amy Beach's Variations on Balkan Themes, Op. 60 used by permission of Alfred Publishing Company, Inc. 


\section{CHAPTER I}

\section{Introduction}

Variations on Balkan Themes, Op. 60 by Amy Beach (1867-1944) is not only one of Beach's most technically challenging pieces, but also one of her finest solo piano works. Composed in 1904, Variations on Balkan Themes reflects a late Romantic style and belongs to the second period of Amy Beach's compositions: a time when Beach was more experimental and would often incorporate folk melodies and contrapuntal techniques into her works. The piece not only reveals the virtuosic nature of her early piano pieces, but also reflects her second-period experimental style by using multiple themes within one set of variations. In this work, Beach's brilliant Lisztian style is combined with a unique tonal structure, and her pianistic trademarks such as the use of trills, tremolos, and chromatic passagework appear frequently throughout the work.

Variations on Balkan Themes exists in four different versions. The earliest version is for solo piano and was published in 1906 by A. P. Schmidt. Beach revised the work later in her life, and A. P. Schmidt published the revision in 1936. Beach also transcribed the work for two pianos in 1942. Finally, there is an orchestral version but only an excerpt "has been unearthed to date...only fifteen unsigned, undated manuscript pages survive: the theme and three variations." It is not clear whether "Beach abandoned the orchestration or whether she completed an orchestration that was subsequently lost or destroyed."2

This research paper centers on an analysis of the 1906 solo piano version. Beach's complex harmonic language and engaging motivic development are well represented in this

\footnotetext{
${ }^{1}$ Hector Valdivia, “Amy Beach (1867-1944),” in Women Composers: Music Through the Ages, Volume 8. Sylvia Glickman and Martha Furman Schleifer, (MI: Thomson Corporation, 1996), 369.

${ }^{2}$ Ibid., 370.
} 
version. The focus is on an analysis of the piece, based on the 1906 solo-piano edition, including descriptions of the character of each variation, and selected harmonic analysis as well as Beach's use of folk songs, pianistic figures, and form. Biographical information on Amy Beach, the influence of important composers such as Beethoven and Liszt, and historical information related to Variations on Balkan Themes are also included, as well as brief descriptions of the 1936 revised solo piano version, the 1942 two-piano version and the incomplete orchestral version. It is hoped through this practical analysis that Variations on Balkan Themes may be studied and performed more often by both student and professional pianists. 


\section{CHAPTER II}

Brief Biography of Amy Beach

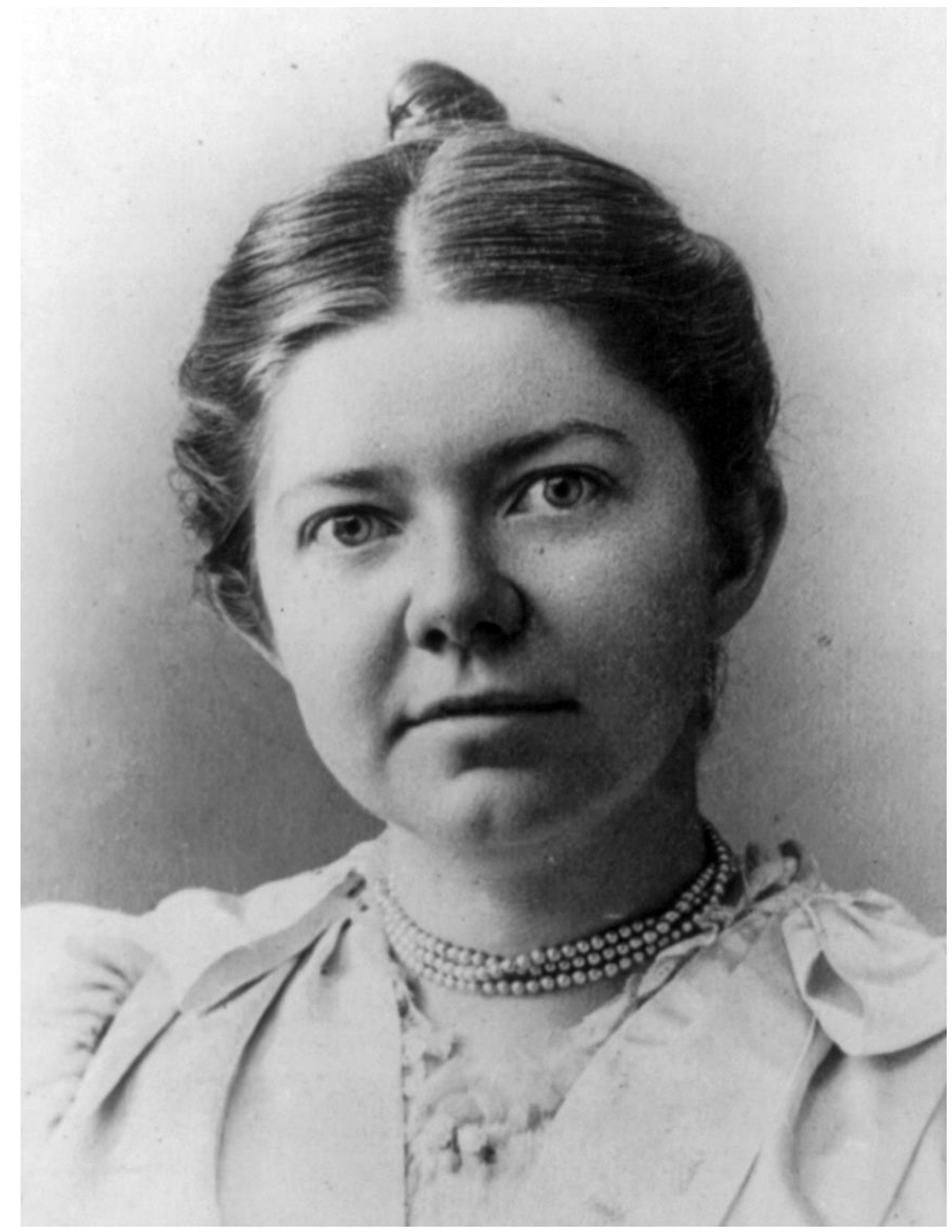

Figure 2.1. Picture of Amy Beach ${ }^{3}$

3 “American Composer and Pianist Amy Beach (1867-1944).” Digital Image. George Grantham Bain Collection (Library of Congress). March 16, 2021. 


\section{Early Years: Child Prodigy}

Amy Marcy Cheney Beach was born on September 5, 1867, in West Henniker, New Hampshire. Her father, Charles Abbor Cheney (1844-1895), was a businessman who worked in the paper manufacturing business; her mother, Clara Imogene Cheney (1846-1911), was a singer and pianist. There was always music making in the house, and Amy Beach could hum music tunes before she could even speak: when she was one year old, she could hum "forty tunes accurately and always in the key that she first heard them." ${ }^{\prime 4}$ Amy Beach had perfect pitch and a remarkable musical memory. "Before Amy was two, when her mother rocked her to sleep, she exhibited a new skill, that of improvising 'a perfectly correct alto to any soprano' that her mother might sing." She was naturally gifted with the ability to build harmonies. When she was four years old, she mentally composed three waltzes and played them on the piano. Amy Beach's extraordinary talent in composition appeared at a very young age!

\section{Music Training}

Amy began piano lessons with her mother at the age of six. In 1875, the Cheney family moved to Boston, and it became time to find a new piano teacher for her. After several of Boston's leading German-trained musicians heard Amy play, they recommended European study for her. However, her parents declined, perhaps because the Cheneys wanted a stable family life and chose not to incur the expenses that foreign study would demand. Instead of European conservatory training, Amy studied piano with Ernst Perabo (1845-1920), a teacher from New England Conservatory, and later with Carl Baermann (1839-1913), a pupil of Franz Liszt.

\footnotetext{
${ }^{4}$ Adrienne Fried Block, Amy Beach, Passionate Victorian: The Life and Work of an American Composer, 18671944. (New York: Oxford University Press, 1998), 2.

${ }^{5}$ Ibid., 5.
} 
At the age of sixteen, Amy Beach made her debut in Boston's main performance space, the Music Hall. She was the soloist for Moscheles's Concerto No. 3 in G Minor with conductor Adolph Neuendorff (1843-1897) and she also performed Chopin's Rondo in Eb Major, Op. 16. The reviews of the concert were very positive, and the Boston audience enjoyed Beach's playing very much. ${ }^{6}$ After the debut, Amy performed Chopin's Concerto in F Minor, Op. 21 at the last concert of the Boston Symphony's 1884-85 season. As a rising young female pianist, this was a significant honor and compliment. Another remarkable concert was her collaboration with conductor Theodore Thomas (1835-1905). During their rehearsal, Thomas wanted to take a slower tempo at the last movement of Mendelssohn's D Minor Piano Concerto, being considerate of Amy's youth. However, Amy felt the tempo was dragging, so she made the orchestra follow her tempo. Thomas had no choice but to follow Amy. Nevertheless, the performance was successful, and there were many positive reviews. ${ }^{7}$

Amy Beach was not only a fine pianist, but also a composer. "The Rainy Day," for voice and piano, was her first published work. It was written in 1880 when she was only 13 and published in 1883 by Oliver Ditson \& Company. This art song "pays homage to Beethoven, for she borrows both melody and accompaniment from the opening of the last movement of Beethoven's Sonata Pathétique, Op. 13, for her opening phrase." It also shows Amy Beach's fondness for prolonging lyrical lines and building harmonic tension.

Amy had only one year of formal training in composition, studying harmony and counterpoint with Junius Hill (1840-1916). Hill was a "church organist and teacher of piano, voice and organ, both privately and at the Boston Conservatory of Music. Fortunately for Amy

\footnotetext{
${ }^{6}$ Adrienne Fried Block, Amy Beach, Passionate Victorian: The Life and Work of an American Composer, 18671944. (New York: Oxford University Press, 1998), 29-30.

${ }^{7}$ Ibid., 33 .

${ }^{8}$ Ibid., 36.
} 
Cheney, he believed in giving women a first-class musical education." ${ }^{\text {9 }}$ During her studies with Hill, she carefully studied J.S. Bach's chorales to learn how to compose four-part harmony. However, when Amy's parents were looking for more professional compositional training for Amy, they received advice from Wilhelm Gericke (1845-1925). Gericke, from Vienna, was a well-known conductor of the Boston Symphony Orchestra at the time. He recommended that Amy Cheney "teach herself composition by studying the great masters." ${ }^{10}$ Amy's parents took his advice, and Amy taught herself most of her compositional skills. She learned counterpoint by studying Bach fugues. She would write down each voice on a separate staff from memory. By doing this, she learned how the contrapuntal structure worked. Amy learned orchestration by translating the treatises of François-Auguste Gevaert (1828-1908) and Hector Berlioz (18031869), though she knew the best way to learn orchestration might be to play every orchestral instrument. ${ }^{11}$ She did not have the opportunity to study all the instruments; hence, she relied on her gifted ears, books and concert attendance. Before attending a concert, Amy would study the orchestral score and know the entire symphony by heart. She was able to write down the whole symphony on paper and would then compare the sounds of the instruments in the concert with the sounds she heard in her head earlier. ${ }^{12}$ This gave her an even more intimate connection with the sound of each instrument. Furthermore, Amy Beach wrote reviews for the orchestral and chamber concerts she attended in her notebook. These reviews "provides substantial insight into her perceptive hearing, analytical abilities, and musical memory." ${ }^{.13}$ Her method of studying composition would be difficult to replicate, as it requires extreme determination, passion, patience, and talent.

\footnotetext{
${ }^{9}$ Adrienne Fried Block, Amy Beach, Passionate Victorian: The Life and Work of an American Composer, 18671944. (New York: Oxford University Press, 1998), 36.

${ }^{10}$ Ibid., 40.

${ }^{11}$ Ibid., 54-55.

${ }^{12}$ Ibid., 55.

${ }^{13}$ Ibid., 56.
} 


\section{Married Life}

In 1885, at the age of eighteen, Amy Cheney married Dr. Henry Beach (1843-1910). Dr. Beach was 42 years old and a doctor "at Massachusetts General Hospital who taught surgery at Harvard Medical School and had a large general practice among Boston's social and cultural elite." ${ }^{14}$ After the marriage, Amy's name usually appeared as "Mrs. H. H. A. Beach" on her concert programs and published compositions. Dr. Beach was a great supporter of Amy's compositional career; however, he did not want his wife to be a concert pianist. After the marriage, Amy gave fewer public recitals. She was not allowed to teach piano, and all the revenue she made from her concerts had to be donated to charities. This was typical of the restrictions for middle-class and upper-class women at the time. To be an ideal wife, she was not allowed to be a professional concert pianist. Nevertheless, Amy gained love, financial security, and career-building assistance from her husband. He introduced Amy to many patrons of the arts, and he encouraged her to compose large works that could establish her as a professional composer. He also taught her how to carefully handle business dealings with her publishers. Moreover, before her marriage, Amy’s mother critiqued her work; after the marriage, Henry also became her critic. Hence, Henry was "husband, patron, sponsor, musical mentor, and - with [Amy's] mother - critic."15

\section{Major Compositional Achievements}

Beach had been composing songs, solo piano works and short choral works until her husband encouraged her to compose a large-scale composition. Her first large-scale work is the Mass in Eb Major, Op. 5. She wrote the "vocal and choral parts in 1886 and 1887 and completed the orchestral score in 1889. Arthur P. Schmidt published the vocal score with piano

\footnotetext{
${ }^{14}$ Adrienne Fried Block, Amy Beach, Passionate Victorian: The Life and Work of an American Composer, 18671944. (New York: Oxford University Press, 1998), 42.

${ }^{15}$ Ibid., 49.
} 
accompaniment in 1890." ${ }^{\prime 16}$ In 1892, Carl Zerrahn (1826-1909), conductor of the Handel and Haydn Society, premiered this work. This work is in a late-Romantic style. "Lush in harmony," "wide-ranging in tonality" and frequent modulations to keys a third apart are all trademarks of her compositional style. ${ }^{17}$ Her earlier art-song writing skills also helped her in setting the texts of this large project. In the Mass, she developed "climaxes with dramatic effectiveness, giving singers the melodic lines that allow them to open up vocally." 18 This piece marks Amy Beach's first success in writing a large, multi-movement work.

However, not everyone was encouraging or sympathetic to females being serious composers. Pianist Anton Rubinstein (1829-1894) claimed that "no woman had ever written a love duet or a lullaby of 'sufficient artistic value to be stamped as type."”19 Antonín Dvořák (1841-1904) stated in an interview "although in the United States there was ample talent that might be trained to become professional composers, that talent was male, not female." ${ }^{20}$ In response, Beach did research on active women composers which also included European female composers from "the seventeenth to the second half of the nineteenth century." ${ }^{21}$ Beach claimed that Dvořák was "very much engaged in his work at the National Conservatory of Music and too new to the country to know about the work of women." Beach found out from "the year 1675 to the year 1885 women have composed 153 works, including 55 serious operas, 6 cantatas, 53 comic operas, 17 operettas, 6 sing-spiele, 4 ballets, 4 vaudevilles, 2 oratorias [sic], one each of farces, pastorals, masques, ballads and buffas." 22 Beach had also included names of "dozens of

\footnotetext{
${ }^{16}$ Block, Amy Beach, Passionate Victorian, 69.

${ }^{17}$ Ibid., 65.

${ }^{18}$ Ibid., 67.

${ }^{19}$ Ibid., 71.

${ }^{20}$ Ibid., 72.

${ }^{21}$ Ibid.

${ }^{22}$ Ibid.
} 
female European composers." ${ }^{23}$ Antonín Dvořák was only in the United States for three months when he made the statement about female composers. Perhaps if he had been here longer and had seen musical events that included female composers, he might have formed a different opinion.

The next major success to make Amy Beach become one of the most significant and influential American female composers was her completion of the "Gaelic" Symphony. Amy Beach was the first female composer to write and publish a symphony in America. This symphony was inspired by Dvořák’s Symphony in E Minor, "From the New World." Dvořák believed that " "the future music of this country [America] must be found upon what are called negro melodies....There is nothing in the whole range of composition that cannot be supplied with themes from this source.' Dvořák named plantation melodies and minstrel show music as sources for the American art music of the future." ${ }^{24}$ However, Beach "objected to Dvořák's ideas, believing that Blacks were no more 'native American' than 'Italians, Swedes or Russians. ${ }^{\prime 25}$ The real traditional American music should be written by the Native Americans; however, "Native American music was too remote from most people's experience to be readily useful." ${ }^{26}$ Hence, she believed "in order to make the best use of folk-songs of any nation as material for musical composition, the writer should be one of the people whose music he chooses, or at least brought up among them." ${ }^{27}$ Despite their different concepts on nationalism and folk music, there are similarities between these two works:

\footnotetext{
${ }^{23}$ Block, Amy Beach, Passionate Victorian, 72.

${ }^{24}$ Ibid., 87.

${ }^{25}$ Ibid.

${ }^{26}$ Adrienne Fried Block, "Amy Beach's Music on Native American Themes," American Music 8, No. 2 (1990): 146, doi:10.2307/3051947.

${ }^{27}$ Ibid.
} 
Both were written according to their composer's own recommendations for creating an American national style; and they are both in the same key, use pentatonic themes, feature oboe and English horn solos in the slow movements, and combine folk idioms with late-Romantic, that is, German, harmonies. $^{28}$

The "Gaelic" Symphony was a huge success, and many women thought of Amy Beach with pride. The poet Elizabeth Porter Gould compared Beach's music to "the heavenly harmonies of angel-choirs." 29 Furthermore, "Gaelic" Symphony was premiered by the Boston Symphony, one of the leading American orchestras, which was also an honor for Amy Beach. In 1900, the Boston Symphony also premiered Beach's Piano Concerto in C\# Minor with Amy Beach as the soloist. This concerto was the first piano concerto written by an American female composer.

Beach was also a successful art-song composer. She wrote approximately 150 songs. These songs make excellent choices for vocal repertoire because they are "effective and sympathetic to the voice." ${ }^{30}$ Her songs are also very emotional and come from the depths of her feelings, a means of expressing her soul through musical language. Moreover, she claimed that "song writing was recreation for her." 31 She would write a song when she was taking a break from working on the larger works.

Beach's most famous song is “The Year's at the Spring." The song uses “triplet figuration [in the accompaniment] to express youthful ardor and exuberance." ${ }^{32}$ The short melodic phrases "suggest a breathlessness that matches the spring morning." 33 Hence, the triplet drive in the accompaniment, the rising short melodic phrases and the increasing dynamic

\footnotetext{
${ }^{28}$ Block, Amy Beach, Passionate Victorian, 89.

${ }^{29}$ Ibid., 102.

${ }^{30}$ Ibid., 146.

${ }^{31}$ Ibid., 146.

${ }^{32}$ Ibid., 150.

${ }^{33}$ Ibid., 151.
} 
markings make the song very emotionally powerful. Because of the directness and simple nature of the song, it is adored by many well-known singers as encore music. Both Marcella Sembrich (1858-1935) and Emma Eames (1865-1952) sang the song at the end of their concerts. ${ }^{34}$ Besides being a successful art-song composer, Mrs. Beach also wrote choir, chamber, and solo piano pieces. Her longest and most technically challenging solo piano work is Variations on Balkan Themes.

Amy Beach was a composer who could successfully write in both large and small forms; her passion, determination and the quality of her music make her one of the most significant American female composers. At the same time, she was also an inspiration for many young female composers.

\section{European Years}

In 1910 and 1911, Mrs. Beach lost both her husband and her mother. She was suddenly left alone. She decided to go to Europe in 1911 to resume her concert and compositional careers, and to travel to a new place to recover from her deep grief. She did not travel alone, but her soprano friend, Marcella Craft (1874-1959), went with her. The first year in Europe, Beach was not able to perform. She was still suffering from the loss of her husband and mother. She gradually resumed her concert life in 1912, and she changed her name from Mrs. H.H.A. Beach to Amy Beach. Her European debut was in Dresden, where she performed her Violin Sonata, Op. 34 with Dr. Wolfgang Bülau. She received positive reviews. "A Dresden review stated that the sonata had 'a fine romantic feeling worked out in clear, readily understandable form' and that Beach was 'a splendid pianist." ${ }^{35}$ She also played a concert in Munich. For this concert, she provided a program by the four B's: Bach, Beethoven, Brahms, and Beach. There were not only

\footnotetext{
${ }^{34}$ Block, Amy Beach, Passionate Victorian, 151.

${ }^{35}$ Ibid., 184.
} 
positive comments, but also harsh reviews for the Munich concert. One Munich critic claimed Beach's tone was “hard and without resonance, her interpretations charmless and without individuality. Her accompaniments to the songs drowned out the singer, he said, because she kept the piano lid up, while her playing of the Brahms 'Rhapsodie,' Op. 119, No. 4, was not exactly clean technically." ${ }^{36}$ Despite the mixed reviews, the requests for copies of her songs had multiplied. She had successfully promoted her compositions in Europe and established herself as a composer and pianist internationally. Her "Gaelic" Symphony and Piano Concerto in C\# Minor were also brought to a European audience in late 1913. The audience enjoyed her music very much; one critic praised Beach as "a possessor of musical gift of the highest kind, a musical nature touched with genius. Strong creative power, glowing fancy, instinct for form and color are united in her work with facile and effortless mastery of the entire technical apparatus. To this is added charm of poetic mood, delicacy and grace of melody, and a gift for rich, soulful harmonization." 37 These last several concerts marked the greatest triumph for Beach in Europe. However, because of World War I, Beach was required to cancel the rest of her European tour and return to America.

\section{Later Years}

After returning to America, Beach first made her residence in Boston. However, despite the warm welcome from her Boston friends, she felt lonely in the large house each time she returned from a concert tour. Also, Boston's music circle was not like Munich, and Beach wanted to be in a more energetic music center. Hence, she decided to move to New York. After she settled in New York, she would also travel to perform and compose. She would spend

\footnotetext{
${ }^{36}$ Block, Amy Beach, Passionate Victorian, 184.

${ }^{37}$ Ibid., 187.
} 
summers at the MacDowell Colony in Peterborough, New Hampshire, to compose and meet other musicians. She inspired many young musicians there and became life-long friends with them.

Beach's other achievements during her later years included being the composer-in residence at St. Bartholomew's Episcopal Church in New York City. She received an honorary master's degree from the University of New Hampshire in 1928. She also served in many leadership positions in such associations as the Society of American Women Composers, the Music Teachers National Association, and the Music Educators National Conference. Mrs. Beach was active in her musical life; however, in 1940, she suffered a heart attack and had to retire from her performing life. In 1944, she died from heart disease in New York City.

Amy Beach was a successful and productive female composer. She composed in many different genres: opera, symphony, concerto and many choral, chamber, keyboard, and vocal works. In 1915 to help educate young composers, Beach published an article called "Music's Ten Commandments as Given for Young Composers." In the article she stated "technic is valuable only as a means to an end. You must first have something to say - something which demands expression from the depths of your soul. If you feel deeply and know how to express what you feel, you make others feel." ${ }^{38}$ Beach had given advice to young composers from her own experience. For her, the expression and inspiration of the music are more important than the technical tools that composers use to attract an audience. Music must come from within, and expression in music cannot be replaced by technique. Technique should be the tool to make musical expression, and music must have depth and soul. Hence, it is significant to explore the expressive content in her music in addition to the technical aspects.

\footnotetext{
${ }^{38}$ Block, Amy Beach, Passionate Victorian, 310.
} 


\section{CHAPTER III}

\section{Compositional Style of Amy Beach}

This chapter focuses on Beach's compositional style through her three compositional periods, and provides information on her melodic treatment, harmonic language, use of rhythm, tempo, dynamics, and texture as well as her utilization of keyboard devices.

Amy Beach composed mainly in a late-Romantic style. She uses traditional forms, but her harmonies are highly chromatic and frequently contain unresolved dissonances. Her harmonic style is rich with Neapolitan chords, augmented sixth chords, even ninth and eleventh chords. Modulations appear often in her music, and she frequently makes use of both commontone and direct modulations.

She composed in both small and large forms. Among the small forms, Beach was especially successful as an art-song composer and she felt song writing was a pleasure for her. She deeply enjoyed expressing her feelings through her lyrical melodic writing. Beach was also praised as the first American female composer to write large-scale art music. Her success in composing the Mass in Eb Major and the "Gaelic" Symphony made her one of the most important female composers in music history. Moreover, extramusical influence also plays a role in Beach's music. In her Variations on Balkan Themes, Op. 60, she uses Balkan melodies to express her sympathy toward the Balkan people.

\section{Three Periods}

According to Marmaduke Sidney Miles's dissertation, “The Solo Piano Works of Mrs. H.H.A. Beach," the composer's writing style can be divided into three periods. This division is based mainly on her solo piano works. Her first period is from Valse Caprice, Op. 4 (1889) to the Children's Album, Op. 36 (1897). The characteristics of her keyboard works during this 
period feature a virtuosic style and brilliant passagework and show the influence of many of Liszt's technical devices, such as octaves, thirds, and trills.

Beach's middle period is from "Scottish Legend: Gavotte Fantastique," Op. 54 (1903) to “Tyrolean Valse Fantasie," Op. 116 (1924). Many of her piano compositions were written during this period. Variations on Balkan Themes, Op. 60, one of her most important piano solo works was composed during this period as well. Her works during this period include Prelude and Fugue, Op. 81 (1914), the "first example of formal contrapuntal writing" 39 in her piano works and Suite française (1907), which is an example of Beach's cyclic treatment of themes. Hermit Thrush, Op. 92 (1922) is based on bird calls, and an example of Beach's search for new material. Her middle-period keyboard compositions are more experimental in character, as she constantly sought new inspiration. Her experiments include incorporating impressionistic devices, folk songs, and contrapuntal techniques into her compositions.

Amy Beach's late period spans works From Six to Twelve, Op. 119 (1927) through Improvisations, Op. 148 (1938). The divisions of her works were based on "a marked lack of compositional output for solo piano." ${ }^{\circ 40}$ Large works like Canticle of the Sun, Op. 123 (1924) for chorus and orchestra and the String Quartet, Op. 89 (1929) were composed during this third compositional period. Her notable solo piano works include Three Piano Pieces, Op. 128 (1932), Out of the Depths, Op. 130 (1932) and Five Improvisations, Op. 148. The characteristics of her works during this period are shorter and simpler in technique, with a tendency toward the "elimination of unnecessary chromaticism." ${ }^{41}$ When dissonance occurs, it is "used as a color

\footnotetext{
${ }^{39}$ Amy Beach, "Variations on Balkan Themes, Op. 60," in Amy Beach Piano Music, ed. by Sylvia Glickman (New York: Da Capo Press, Inc., 1982), v.

${ }^{40}$ Marmaduke Sidney Miles, "The Solo Piano Works of Mrs. H.H.A. Beach," DMA diss., (Peabody Conservatory of Music, 1985), 23.

${ }^{41}$ Ibid., 53.
} 
device and is often unresolved, in a fashion more typical of twentieth-century writing." ${ }^{\prime 42}$ Therefore, though most of Amy Beach's compositions reveal a late-Romantic style, there are still differences among her compositional periods.

\section{Melodic Treatment}

There are two types of melodic style that Beach used: one is more vocal in character with long melodic lines, and the other is more instrumental with short, motivic ideas. The longer, more vocal melodies are usually associated with slower tempi and more regular phrase structures; the primarily instrumental melodies are quicker in tempi and display more irregular phrase structures. Nevertheless, Beach could employ both types of melodic styles within a single piece and they could serve as melodic styles for contrasting sections.

\section{Harmonic Language}

Beach's interesting harmonic language identifies her compositional style more than any of her other characteristics. As already observed, she frequently uses Neapolitan chords, augmented-sixth chords, and pedal tones in her compositions. She "highly emphasizes the use of seventh chords built on all degrees of the scale, in addition to some use of chords of the ninth and eleventh. Diminished and dominant seventh chords are often utilized in succession, without resolution, in an impressionistic fashion. ${ }^{43}$ Successive augmented triads also occasionally appear in her compositions. She enjoyed applying bVI chords in her works, and one of her signature chord progressions is: $\mathrm{bVI}-\mathrm{Fr}+6-\mathrm{V}-\mathrm{I}$. Another signature of Beach's harmonic style is the "use of the Neapolitan to tonic relationship, particularly in summation at the end of a work." "Other unmistakable trademarks are the use of the major submediant in major as well as

\footnotetext{
${ }^{42}$ Marmaduke Sidney Miles, “The Solo Piano Works of Mrs. H.H.A. Beach,” DMA diss., (Peabody Conservatory of Music, 1985), 53.

${ }^{43}$ Ibid., 147.

${ }^{44}$ Ibid., 148.
} 
minor keys, free use of the major and minor modes within a given key, and enharmonic modulations." 45 Common-tone modulations, abrupt change of keys, and modulations involving "phrase repetition on the new tonal level"46 are other types of modulations that Beach employs.

Like many other $19^{\text {th }}$-century composers, Beach was also interested in utilizing chromaticism in her compositions. Though the chromaticism affects the stability of the key, it makes her compositions more interesting. In Rosemary and Rue, Op. 27, No. 3, Beach applied a tonally unstable melody in one voice, and "an extremely dissonant countermelody in another, but with a pedal tone reminding the listener of the intended key. ${ }^{47}$ Beach's experimentation with chromaticism makes her compositions more captivating.

In addition to her signature chords, modulations and chromaticism, Amy Beach is also aware of the significance of tonal relationships in her works. She often applies the "parallel minor, or a key a chromatic third away from the tonic" 48 for contrasting sections in major keys. In minor keys, she uses the "more common relative major key for the contrasting section. Often, tonal ambiguity exists at the beginning of a new section, with the new key only firmly established several measures into the section." ${ }^{49}$ Such devices add intriguing intricacy to Beach's harmonic language.

\section{Rhythm, Tempo, Dynamics, and Texture}

Unlike many of her contemporaries who were progressive and innovative with the treatment of rhythm, tempo and dynamics, Beach was more conservative. She was one of the transitioning composers who lived between the $19^{\text {th }}$ and $20^{\text {th }}$ centuries. Instead of joining the

\footnotetext{
${ }^{45}$ Marmaduke Sidney Miles, “The Solo Piano Works of Mrs. H.H.A. Beach,” DMA diss., (Peabody Conservatory of Music, 1985), 147.

${ }^{46}$ Ibid.

${ }^{47}$ Ibid., 148.

${ }^{48}$ Ibid.

${ }^{49}$ Ibid.
} 
$20^{\text {th }}$-century avant-garde, she decided to remain in the $19^{\text {th }}$-century Romantic style. She uses simple or compound meters, and the meter usually will remain the same for a section of the piece or an entire piece. Syncopation and non-metrical accents usually appear in her pieces. "Melodies tend to appear in a clear-cut format rhythmically, which corresponds to the meter utilized. Many examples of two against three, or three against four exist, usually in the framework of a constant accompaniment pattern in one rhythm, with a melody containing different rhythmical characteristics appearing simultaneously. ${ }^{, 50}$ Nevertheless, Beach will use the subdivision of note values to achieve "a rhythmical acceleration toward the midpoint, or point of most tension in a work." ${ }^{51}$

Beach's tempo markings are loosely indicated, and she would leave it for the performers to decide. Metronome markings are given sometimes, but not always. Most of the tempo makings are character related, for example, she would use "poco più lento ma sempre capriccioso," "Allegro ma non tanto," or “Allegretto scherzando." For Beach, tempo descriptions are used to build the character of the piece, instead of just purely indicating how fast a performer needs to play. Ritardando and accelerando are other devices that Beach likes to use to build tension in the music. Hence, Beach's tempo choices are very performer based and deeply rooted in the $19^{\text {th }}$-century style.

Beach's dynamic marks range broadly, typically from $p p p$ to fff in most of her piano works. Unlike her use of meter and tempi, her dynamic markings change frequently. Sometimes

\footnotetext{
${ }^{50}$ Marmaduke Sidney Miles, “The Solo Piano Works of Mrs. H.H.A. Beach,” DMA diss., (Peabody Conservatory of Music, 1985), 149.

${ }^{51}$ Ibid.
} 
they can change dramatically from "one measure to the next." 52 Frequent crescendo,

diminuendo, sforzando and accents are devices that Beach utilizes to increase the character of the piece.

Beach's compositions usually reveal homophonic texture and her keyboard writing typically has "full chords throughout." 53 Also, her "use of octaves in the bass, and filled chords encompassing the octave in the upper part of the texture" lead to an "impression of an orchestral sound pianistically." ${ }^{54}$ Besides the homophonic format, Beach is also interested in bringing in counterpoint into her compositions. Prelude and Fugue, Op. 81, and Fantasia Fugata, Op. 87, are examples of her contrapuntal writing.

\section{Keyboard Devices}

Beach was "a pianist of superior technical ability, who wrote pieces for her own use."55 Her use of keyboard devices is very similar to that of Franz Liszt. She applies "parallel octaves in both hands, (and) parallel octaves at intervals a third, sixth, and tenth apart." 56 Trills, tremolos in thirds, double thirds and parallel sixths frequently appear in Beach's compositions. Fast scale passages and rapid arpeggios are also Beach's way to please audiences and show off her virtuosity. Despite the "bravura style of writing, Mrs. Beach always thought from the keyboard artist's point of view. While her music is often demanding technically, it is still approachable, and it always feels comfortable underneath the hand." 57

\footnotetext{
${ }^{52}$ Marmaduke Sidney Miles, “The Solo Piano Works of Mrs. H.H.A. Beach,” DMA diss., (Peabody Conservatory of Music, 1985), 150.

${ }^{53}$ Ibid.

${ }^{54}$ Ibid., 151.

${ }^{55}$ Ibid.

${ }^{56}$ Ibid., 152.

${ }^{57}$ Ibid., 153.
} 
With all the elements in Beach's compositional style, she is "most distinguished by the lyrical melodies which appear in her works, and by her harmonic language." ${ }^{, 5}$ Despite some of her experimentation with harmony, such as the impressionistic use of unresolved seventh chords, her music largely remains in a late-Romantic style. Beach's earlier works are more virtuosic and technically demanding; her late works emphasize more the musical content and inspiration.

Hence, as mentioned in the previous chapter, the more Beach evolves through her compositions, the more she values musical expression and content. Technical devices become more like tools and the most essential element of her music will be the emotional depth.

${ }^{58}$ Marmaduke Sidney Miles, “The Solo Piano Works of Mrs. H.H.A. Beach,” DMA diss., (Peabody Conservatory of Music, 1985), 153. 


\section{CHAPTER IV}

\section{Historical Background of Variations on Balkan Themes}

Like many other late 19th-century composers, Amy Beach was interested in folk music. Her contemporary Edward MacDowell (1860-1908) applied American Indian melodies and rhythms in his Indian Suite for orchestra (1892). Antonín Dvořák (1841-1904) used African American themes to represent American music in the New World Symphony (1893). Beach also incorporated many folk tunes into her music. In her piano suite Eskimos, Op. 64 (1907), she quoted one or more Native American tunes in each piece. In her solo piano work $O$ ! The Fair Hills of Eire, Op. 91 (1922), she used Irish folk melodies to portray the Irish landscape. O! The Fair Hills of Eire is also an example of Amy Beach's illustration of her Anglo-Irish heritage. In Variations on Balkan Themes (1906), Beach utilized Balkan melodies to express her sympathy toward the Balkan people.

\section{The Balkan Region}

About the time Beach wrote Variations on Balkan Themes, the political situation in the Balkans was frequently in the news. The Balkans is also known as "Balkan Peninsula" and "Southeastern Europe." 59 The Balkans is "bounded by the Adriatic and Ionian Seas in the West, the Aegean Sea in the South, and the Black Sea in the East. ${ }^{60}$ It includes Slovenia, Croatia, Bosnia and Herzegovina, Serbia, Montenegro, Kosovo, Macedonia, Bulgaria, Romania and Albania. Portions of Turkey and Greece are also in the Balkan region (see Figure 4.1).

\footnotetext{
${ }^{59}$ R. Craig Nation, "The Balkan Region in World Politics," in War in the Balkans, 1991-2002. (PA: Strategic Studies Institute, US Army War College, 2003), 1-2.

${ }^{60}$ Ibid., 2.
} 


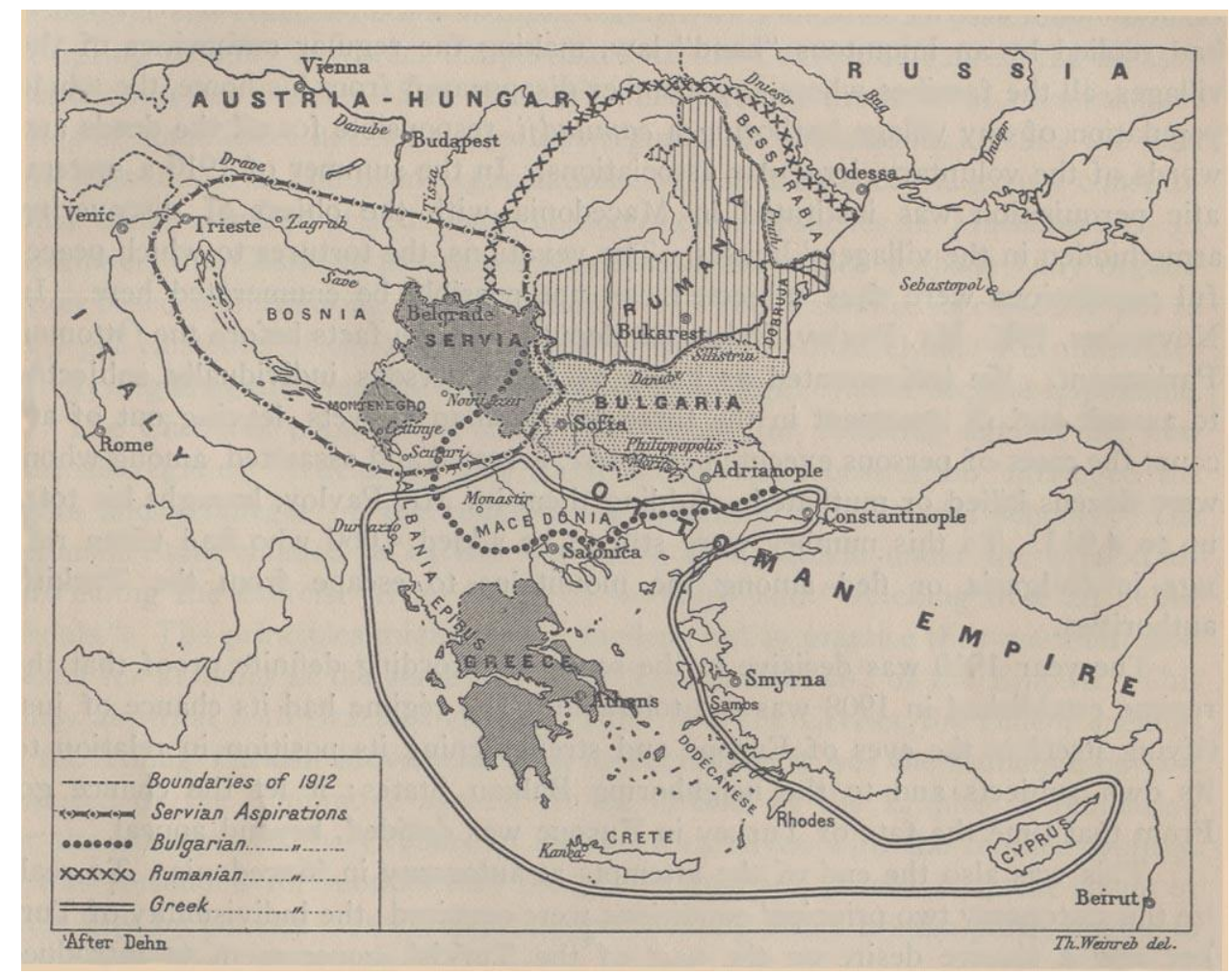

Figure 4.1. Map of the Balkans ${ }^{61}$

The Ottoman Empire had controlled most of the Balkan region since 1400, for more than 400 years. In the $16^{\text {th }}$ century, the Ottoman Empire's power had reached its peak. In the $19^{\text {th }}$ Century, there was a rise of nationalism, and many countries in the region fought for independence. Greece declared its independence in $1821 .^{62}$ Romania, Serbia and Bulgaria also fought for their independence. With the Treaty of Berlin, part of Bulgaria was still under the influence of Turkey, and Macedonia "stayed completely under Turkish rule." ${ }^{\prime \prime}$ The Macedonians wanted independence. In 1903, the tension between the Macedonian and Turkish armies increased, and brought the problem to international attention.

\footnotetext{
61 "Balkan Aspirations - this map from 1914 illustrates the territorial ambitions of 4 nations: Bulgarians, Greeks, Romanians and Serbs.” Digital Image. Reddit. March 15, 2021.

${ }^{62}$ Knowledgia, "The First Balkan War," May 29, 2019, video, 10:30, https://www.youtube.com/watch?v=0LvLr1UjCVw.

${ }^{63}$ E. Douglas Bomberger, "Motivic Development in Amy Beach's Variations on Balkan Themes, Op. 60," American Music 10, No. 3 (1992): 327, doi:10.2307/3051598.
} 


\section{Origin of the Balkan Themes}

In the preface of Amy Beach's Variations on Balkan Themes, she describes the Balkan

folk songs as:

Haunting melodies, reflecting, mirror-like, the rare beauty and pathos of mountain legend, the tragedy and happiness of a wondrous people and a primitive life. Of unknown origin, these tunes have passed from generation to generation of peasants who could neither read nor write music. They are to be heard everywhere in the vicinity of the mountains and neighboring villages; sung by the little peasant-girls as they dance, played by the shepherds on their pipes and fiddles, chanted by the soldiers at their bivouac fires, and loved by every one. ${ }^{64}$

Beach gratefully "acknowledges her indebtedness to the Reverend and Mrs. William W. Sleeper for the folk-songs obtained during their missionary life in [the Balkan] region; also to them and to Mrs. May Sleeper Ruggles for interesting historical details of words and music." 65 Reverend William Washburn Sleeper (1855-1927) was a Wellesley professor and Protestant missionary. ${ }^{66}$ Mrs. May Sleeper Ruggles was Rev. Sleeper's sister. Beach heard Rev. Sleeper play several Balkan melodies on the piano during his and his wife's lecture on Balkan life and customs. ${ }^{67}$ Beach was inspired by the tunes and believed they could be developed. Before she received an official copy of the melodies from the Sleepers, Beach already wrote down the tunes from memory. When the Sleeper's copy arrived, just one insignificant note needed to be changed. $^{68}$

\footnotetext{
${ }^{64}$ Amy Beach, "Variations on Balkan Themes, Op. 60," in Amy Beach Piano Music, ed. by Sylvia Glickman (New York: Da Capo Press, Inc., 1982), preface.

${ }^{65}$ Ibid.

${ }^{66}$ Adrienne Fried Block, Amy Beach, Passionate Victorian: The Life and Work of an American Composer, 18671944. (New York: Oxford University Press, 1998), 122.

${ }^{67}$ Ibid., 123.

${ }^{68} \mathrm{Ibid}$.
} 


\section{Four Balkan Themes}

Amy Beach used four Balkan themes in Variations on Balkan Themes: "O Maiko Moya" (“O My Poor Country”), "Stara planina” (“Ancient Mountain”), "Nasadil e dado” (“Grandpa Has Planted A Little Garden"), and "Macedonia." "O Maiko Moya" is a Serbian song, and it is the principal theme for Variations on Balkan Themes. This theme is the "primary source for much of the work's structural, harmonic and motivic material." ${ }^{\prime 69}$ It is the only theme applied in the first five variations (see Figure 4.2). The text is somber, dark, and mournful. It is a lament for the Serbians who were suffering under the Ottoman Empire's control:

O my poor country, to thy sons so dear,

Why art thou weeping, why this sadness drear?

Alas! Thou raven, messenger of woe,

Over whose fresh grave moanest thou so ${ }^{70}$

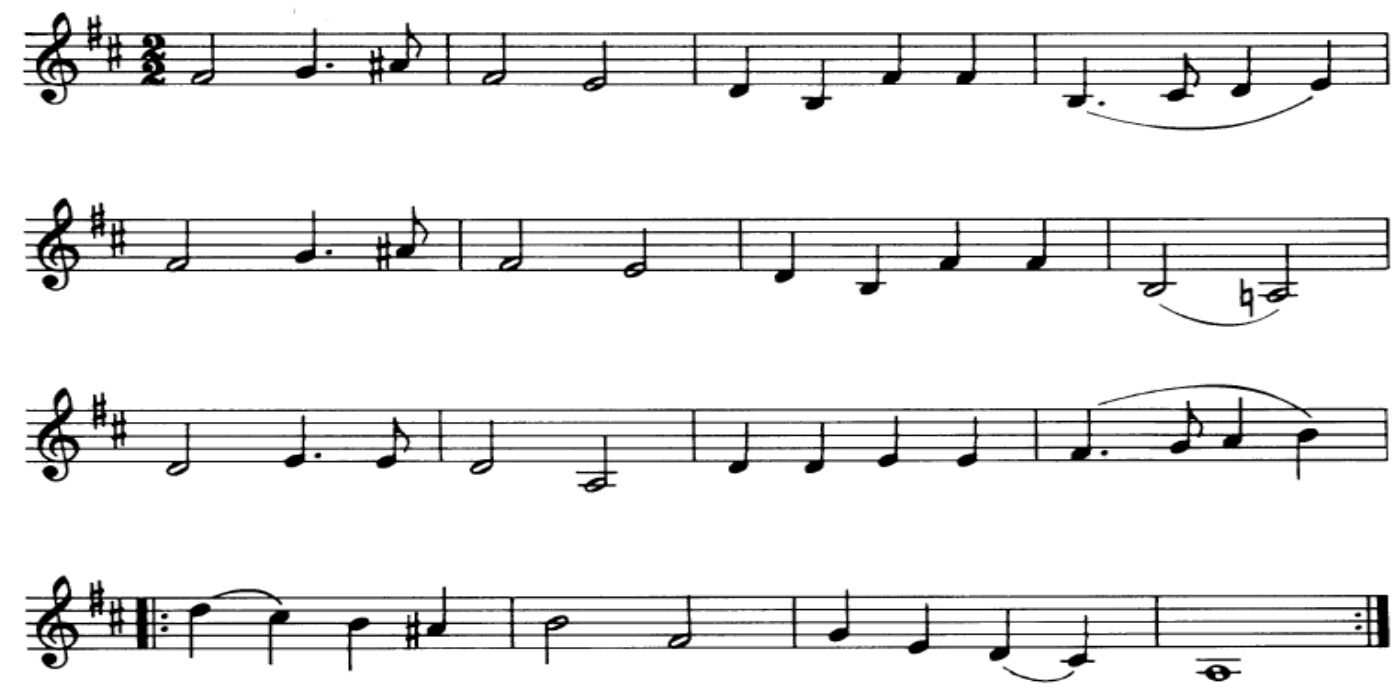

Figure 4.2. "O Maiko Moya"71

${ }^{69}$ Hector Valdivia, “Amy Beach,” in Women Composers: Music Through the Ages, Volume 8. Sylvia Glickman and Martha Furman Schleifer, (MI: Thomson Corporation, 1996), 369.

${ }^{70}$ Amy Beach, "Variations on Balkan Themes, Op. 60," in Amy Beach Piano Music, ed. by Sylvia Glickman (New York: Da Capo Press, Inc., 1982), preface.

${ }^{71}$ Musical Example from: E. Douglas Bomberger, "Motivic Development in Amy Beach's Variations on Balkan Themes, Op. 60," American Music 10, No. 3 (1992): 329. 
The other three themes appear less frequently and serve more as compositional variations. "Stara planina" first appears as a prelude in Variation VI. The text of "Stara planina" has "highly charged political overtones."72 In E. Douglas Bomberger's "Motivic Development in Amy Beach's Variations on Balkan Themes, Op. 60," he says "the text, of which Beach has one verse in her copy, evokes the memory of some of Bulgaria's great leaders of the period before the Turkish occupation of 1396, as seen through the perspective of the ancient mountains, or stara planina." ${ }^{73}$ Like the text, the music is noble and emphasizes the minor second and augmented second intervals. The augmented second is an important interval for Bulgarian folk music (see Figure 4.3). Hence, the music and the text reflect each other. Beach's incorporation of this folk tune also expresses her political intentions in Variations on Balkan Themes.

Ancient mountain, ancient mountain, Who shall in thee an army lead, Since there is not the King proud, King Karana, King Karana? ${ }^{74}$

\footnotetext{
72 E. Douglas Bomberger, "Motivic Development in Amy Beach's Variations on Balkan Themes, Op. 60," American Music 10, No. 3 (1992): 330.

${ }^{73}$ Ibid., 328.

${ }^{74}$ Adrienne Fried Block, Amy Beach, Passionate Victorian: The Life and Work of an American Composer, $1867-$ 1944. (New York: Oxford University Press, 1998), 124.
} 

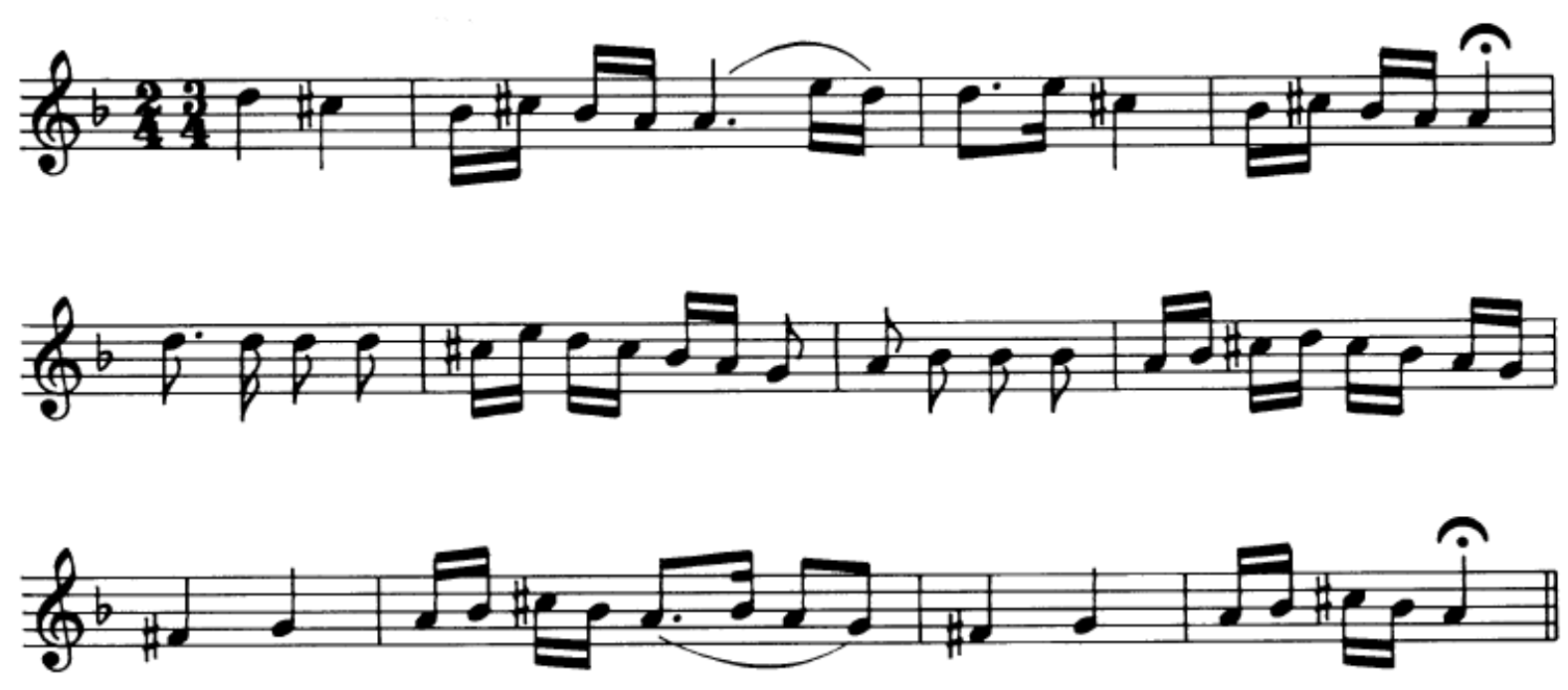

Figure 4.3. "Stara Planina"75

"Nasadil e dado" only appears once at the end of Variation VI. Unlike the other two folk songs with explicit political overtones, "Nasadil e dado" may be a metaphor for planting the seeds of freedom in the Balkan people. The text is very simple, and the music is much happier and lighter (see Figure 4.4).

Grandpa has planted a little garden, Little Garden, Little Garden.

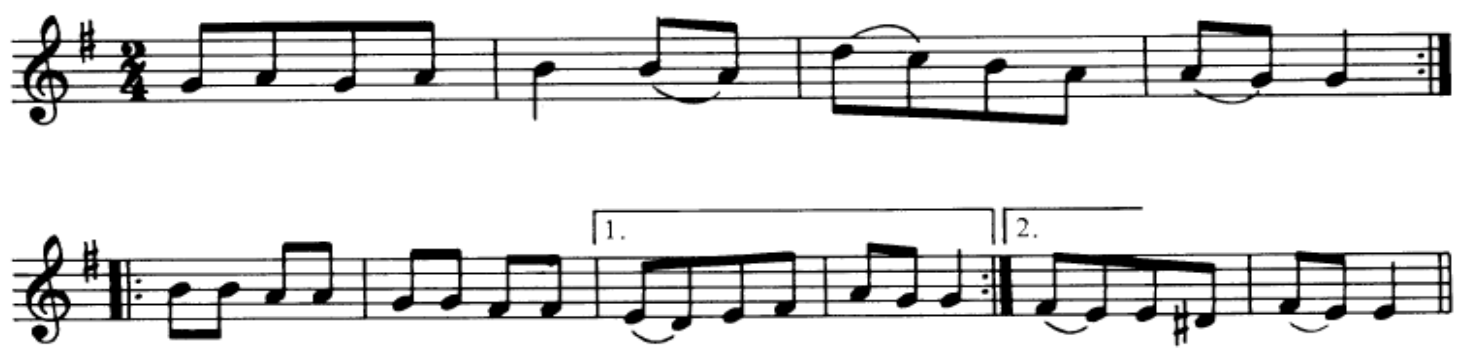

Figure 4.4. "Nasadil e dado"76

\footnotetext{
${ }^{75}$ Musical Example from: E. Douglas Bomberger, "Motivic Development in Amy Beach's Variations on Balkan Themes, Op. 60," American Music 10, No. 3 (1992): 329.

${ }^{76}$ Musical Example from: E. Douglas Bomberger, "Motivic Development in Amy Beach's Variations on Balkan Themes, Op. 60," American Music 10, No. 3 (1992): 329.
} 
The last theme "Macedonia" appears in Variation VIII and the cadenza. The text describes "the suffering of both countries [Bulgaria and Macedonia] at the hands of the Turks and begs for help from 'my brother' in freeing the country from 'slavery.",77 Based on the text, “'Macedonia' likely dates from the period after 1878, when Bulgaria was free from Turkish rule and Macedonia was not. "78 The music also reflects the pain of the texts through the descending melodic lines in the Moderato section and crying for help through the Allegro section of the folk song (see Figure 4.5).

Macedonia, Macedonia, Sings a song of age-long sadness: "Where, O where, has gone my freedom, Where, $\mathrm{O}$ where, the years of happiness, Where have all my hopes been buried, When shall come the resurrection?"

Macedonia strains at shackles, Calls and prays in her long grieving: "Oh, thou Bulgar, cross the border, Cross the line that separates us, Lift the yoke from wearied shoulders, Help me, Bulgar, Oh, my brother!"79

${ }^{77}$ E. Douglas Bomberger, "Motivic Development in Amy Beach's Variations on Balkan Themes, Op. 60," American Music 10, No. 3 (1992): 330.

${ }^{78}$ Ibid.

${ }^{79}$ Florence Hudson Botsford, Folk Songs of Many Peoples: With English Versions by American Poets. (New York: The Womans Press, 1921), 188. 

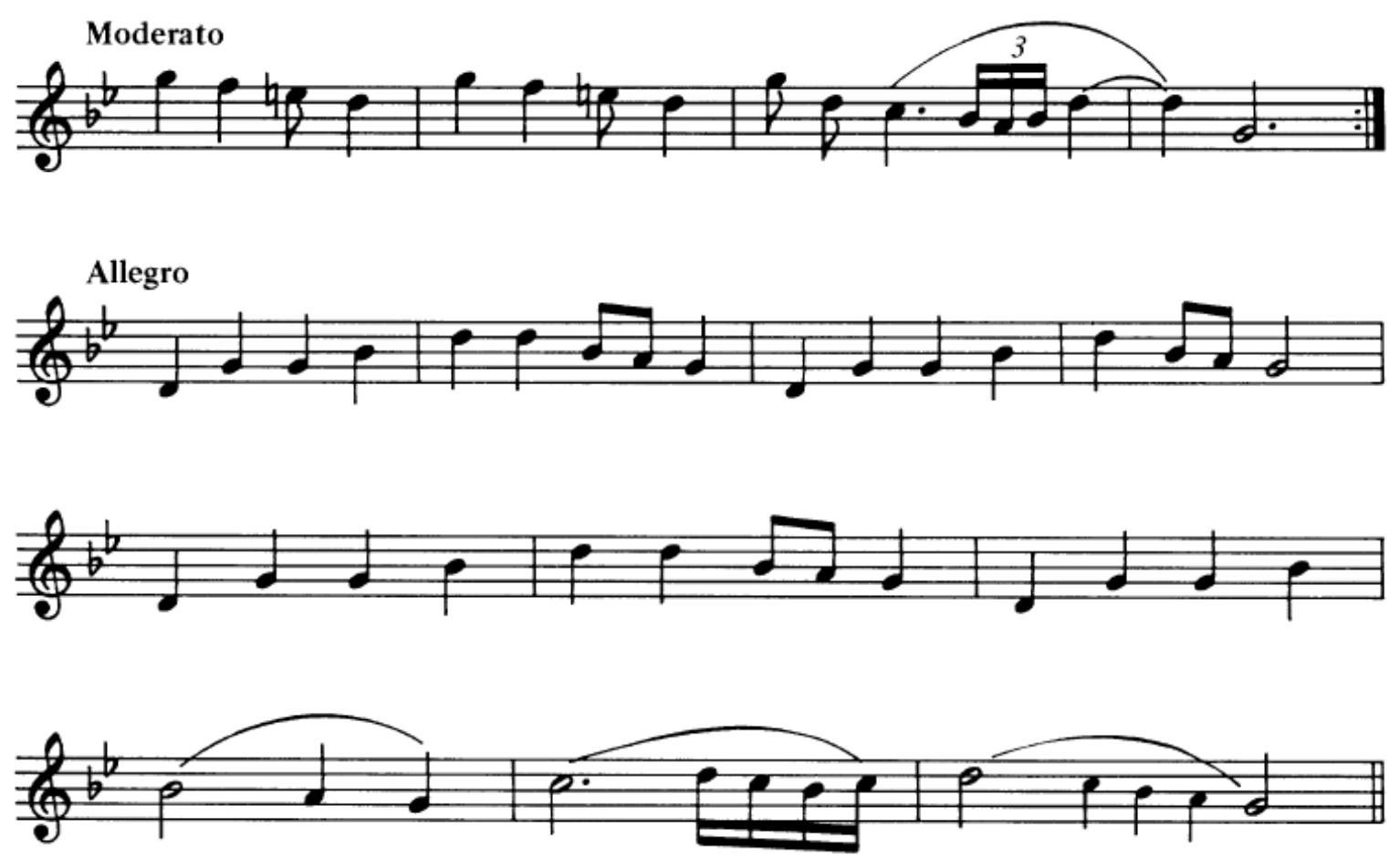

Figure 4.5. "Macedonia"80

All four Balkan folk melodies have political connotations, and Amy Beach must have recognized these political implications. Hence, Amy Beach's use of these melodies can be viewed as her sympathy toward the Balkan people.

${ }^{80}$ Musical Example from: E. Douglas Bomberger, "Motivic Development in Amy Beach's Variations on Balkan Themes, Op. 60," American Music 10, No. 3 (1992): 330. 


\section{CHAPTER V}

\section{Analysis of Variations on Balkan Themes}

Variations on Balkan Themes is Amy Beach's longest and most technically demanding solo piano work. It is a set of character variations with fantasy elements. The work begins with a 20-measure principal theme (“O Maiko Moya”) which is followed by eight variations. Beach gives each variation a distinct character, including a barcarolle, a fantasy, a Hungarian dance, and a funeral march. Due to the work's overall fantasy-like nature, it does not develop around one theme, but contains four distinct themes: "O Maiko Moya," "Stara planina," "Nasadil e dado" and "Macedonia." Nevertheless, the main motive of this 30-minute piece is taken from the principal "O Maiko Moya" theme. As the work progresses, each variation becomes freer in length. There is also a cadenza at the end of the piece and a return of material from the second variation. This chapter provides an analysis of Variations on Balkan Themes that includes the character of each variation, the form, the pianistic figures and selected harmonic analysis as well as Beach's use of folk tunes.

\section{Theme}

The piece opens with the Balkan melody "O Maiko Moya" in C\# minor with a melancholy character. Beach follows the folk tune closely and harmonizes it with a chorale texture. This main theme is in a binary form with a small coda at the end. The first eight measures are the A section, and it is in $\mathrm{C \#}$ minor with a sad and moving character; the $\mathrm{B}$ section extends from measure 9 to 16, and it is in E major with a majestic and noble character. The last four measures act as a coda, and they are a repeat of measure 13 to 16 with a much softer dynamic (see Figure 5.1). 


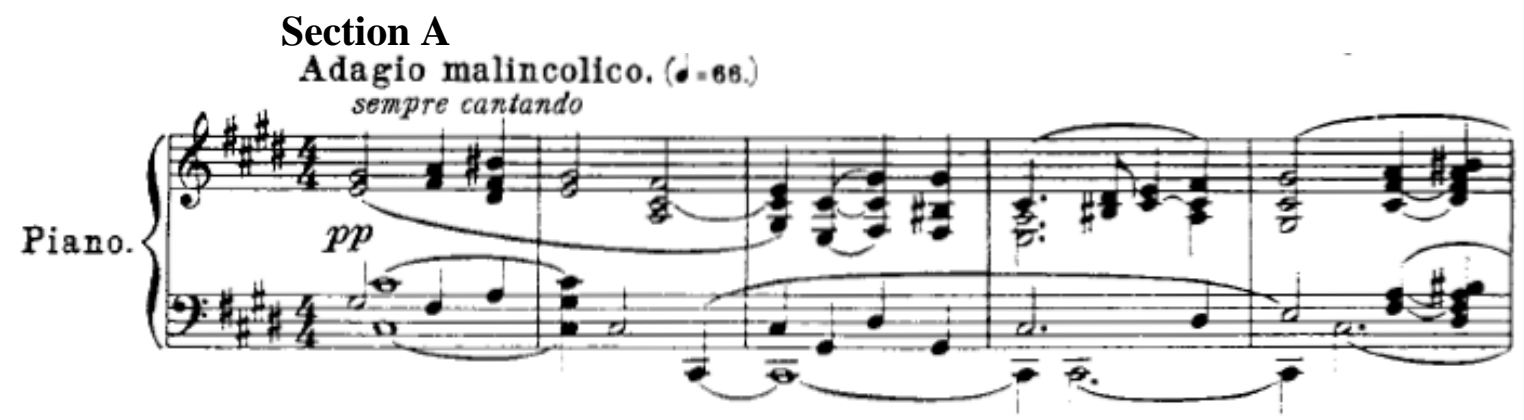

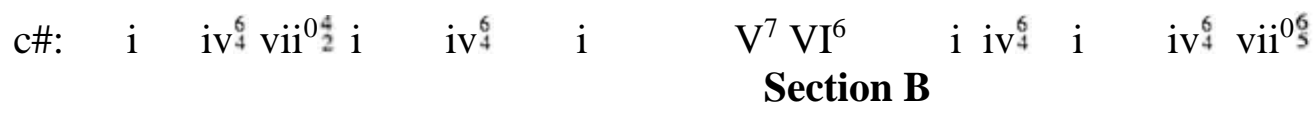

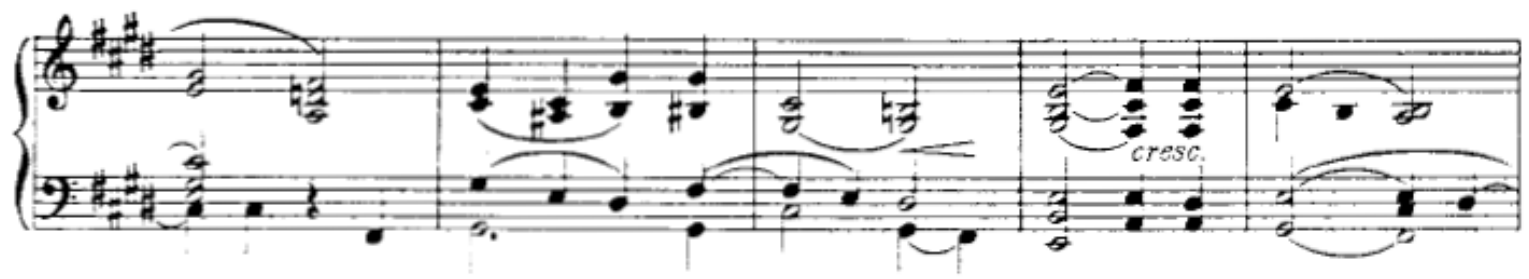

c\#: $\quad \mathrm{i} \quad \mathrm{N}^{6} \quad \mathrm{i}^{6}$

$$
\mathrm{E}: \mathrm{vi}^{6} \mathrm{vii}_{2}^{4} / \mathrm{V} \mathrm{V} \mathrm{V} / \mathrm{vi} \text { vi } \quad \mathrm{iii} \quad \text { I } \mathrm{ii}^{6} \mathrm{vii}_{4}^{0} \text { vi } \mathrm{ii}^{7} \quad \mathrm{~V}^{4}
$$

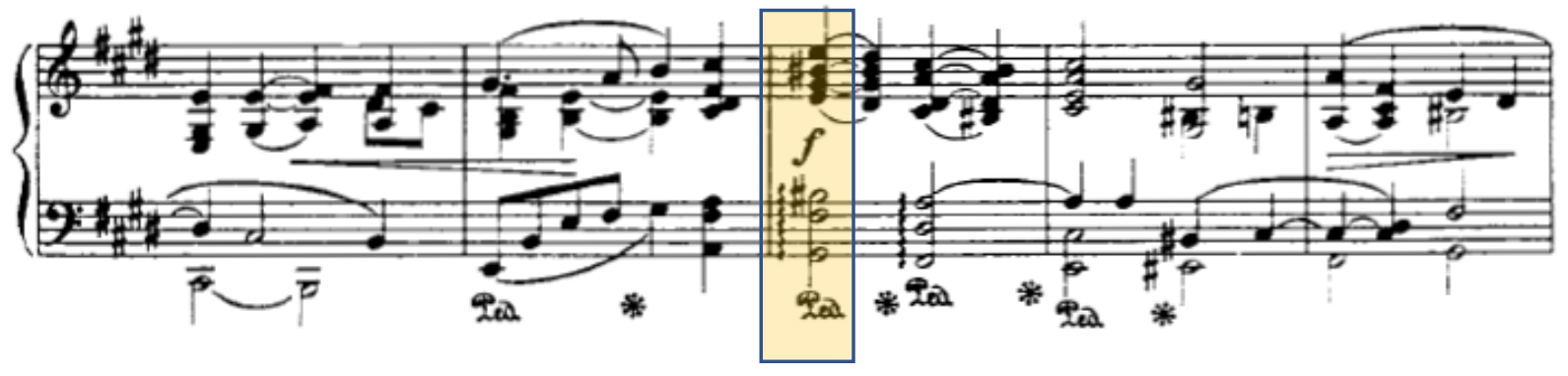

E: vi $\quad \mathrm{V} \quad \mathrm{I} \quad \mathrm{vii}^{\odot^{4}}$

Coda

$\mathrm{c \# :} \mathrm{ii}^{{ }^{4}}{ }^{4} \quad \mathrm{~V} \quad \mathrm{ii}^{\odot_{5}^{6}} \mathrm{vii}^{0^{4}} \mathrm{VI}_{4}^{6} \quad$ iii $\quad$ iv $\quad \mathrm{V}$

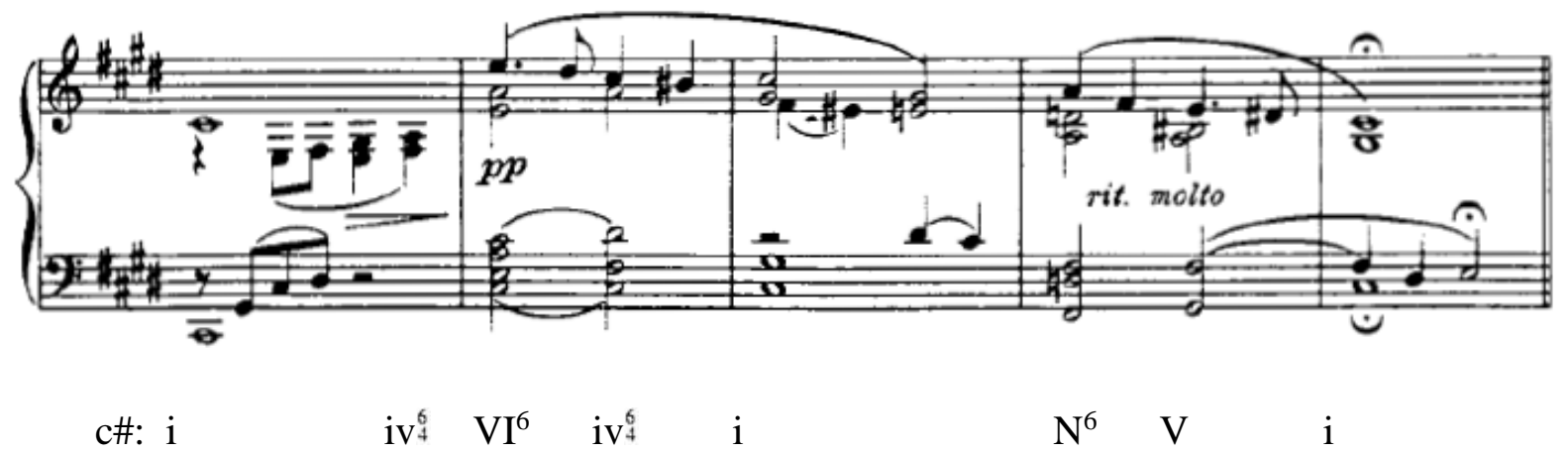

Figure 5.1. Theme, mm. 1-20. 
Furthermore, the opening three-note motive is also significant to this piece. The first three note "G\#-A - B\#" are made of a minor second and an augmented second. "The most common form of nondiatonic scale in Bulgarian folk music uses an augmented second, typically between degrees 2 and 3." ${ }^{\prime 81}$ Beach emphasizes this interval in the initial three-note motive, A to

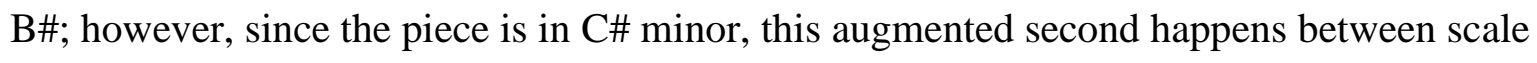
degrees 6 and 7. It is Beach's way of transforming "the Bulgarian Scale into the harmonic form of C-sharp minor." ${ }^{, 82}$ Moreover, this leading tone B\# does not resolve to the expected C\#, instead it goes to G\#. This creates more melodic tension for the composition.

\section{Variation I}

Variation I is a canon in C\# minor. It maintains the melancholy character of the theme but with more movement. The form of this variation is also binary with a coda, and it has 20 measures like the theme. It begins simply with two voices, but soon the texture becomes denser. From m. 9, the canon is interwoven with the chords. The texture becomes chordal and contrapuntal. In m. 13, Beach uses a rolled chord in the left hand to highlight the climax of this variation. Moreover, this rolled chord is a I chord in E major in this variation, but Beach uses a V chord in $\mathrm{C \#}$ minor in the theme. Hence, despite that Beach uses the same key scheme (c\# -- Ec\#) both for the Theme and for Variation I, the chords she chooses are not exactly the same. In the last measure, Beach uses notes and a rhythm that directly lead into Variation II. "O Maiko Moya" is the only folk tune used in this variation (see Figure 5.2).

\footnotetext{
${ }^{81}$ E. Douglas Bomberger, "Motivic Development in Amy Beach's Variations on Balkan Themes, Op. 60," American Music 10, No. 3 (1992): 332.

${ }^{82}$ Ibid.
} 

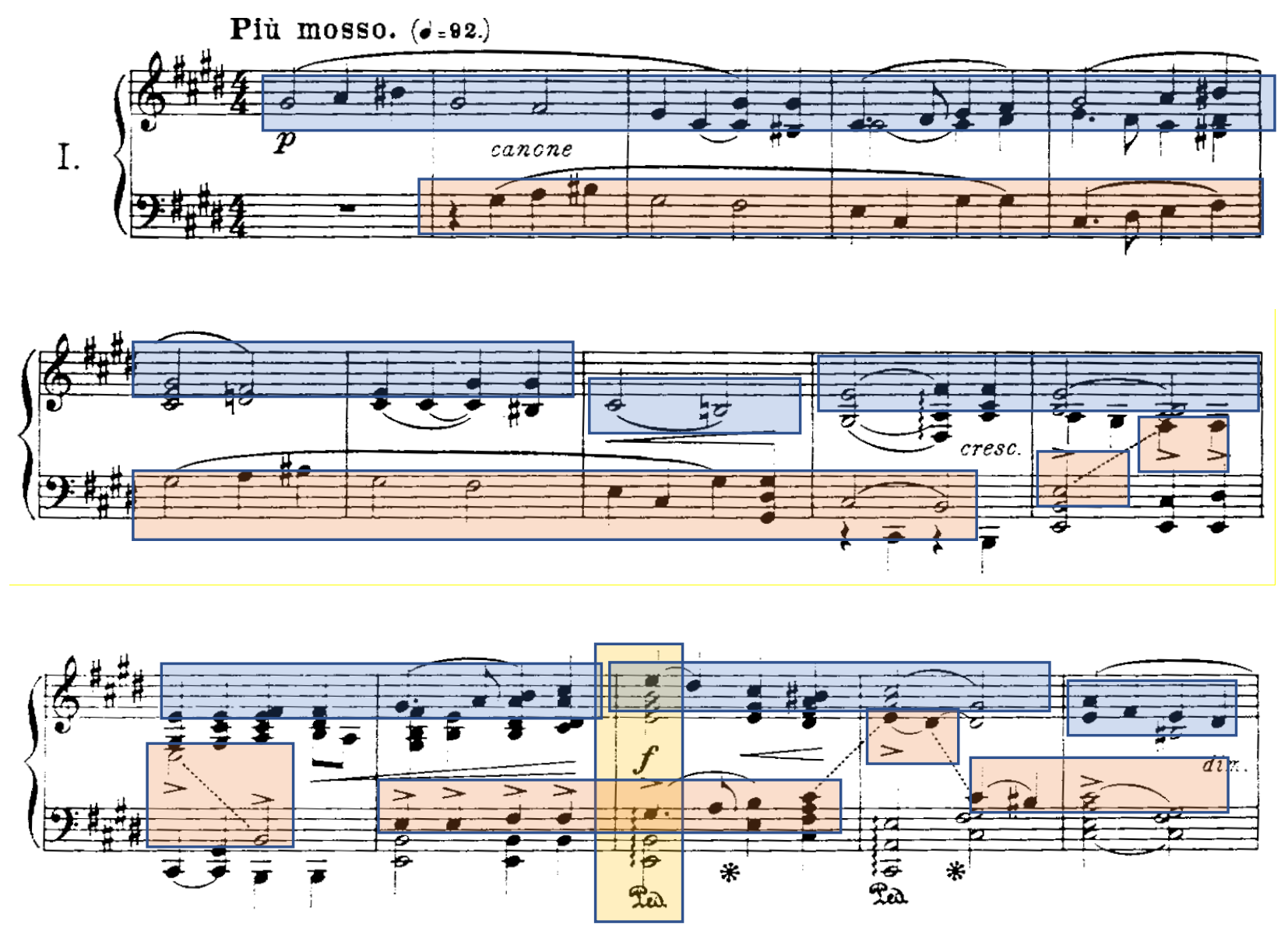

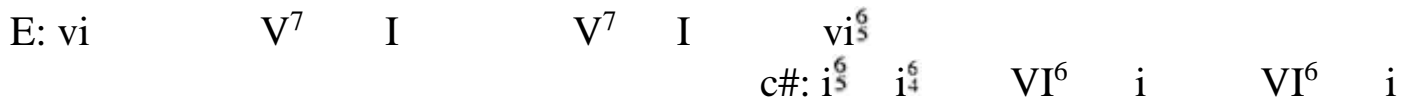

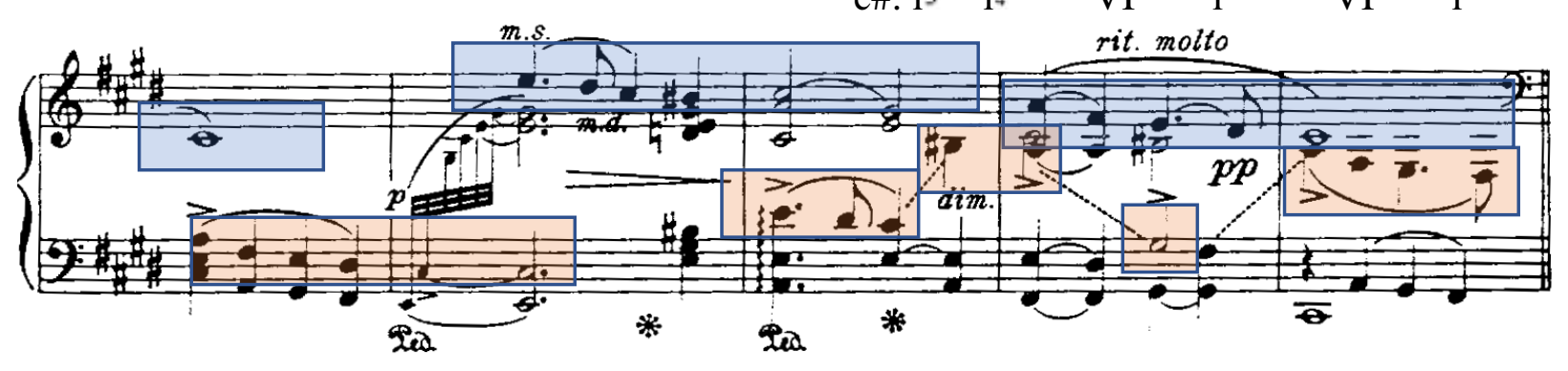

Figure 5.2. Var. I, mm. 1 -- 20.

\section{Variation II}

Variation II is very Lisztian, virtuosic and majestic. The form of this variation is still

binary and 20 measures long. The "O Maiko Moya" melody appears as the three-note motive

(G\# --A - B\#), but it is constantly interrupted by the virtuosic pianistic figures (see Figure 5.3). 

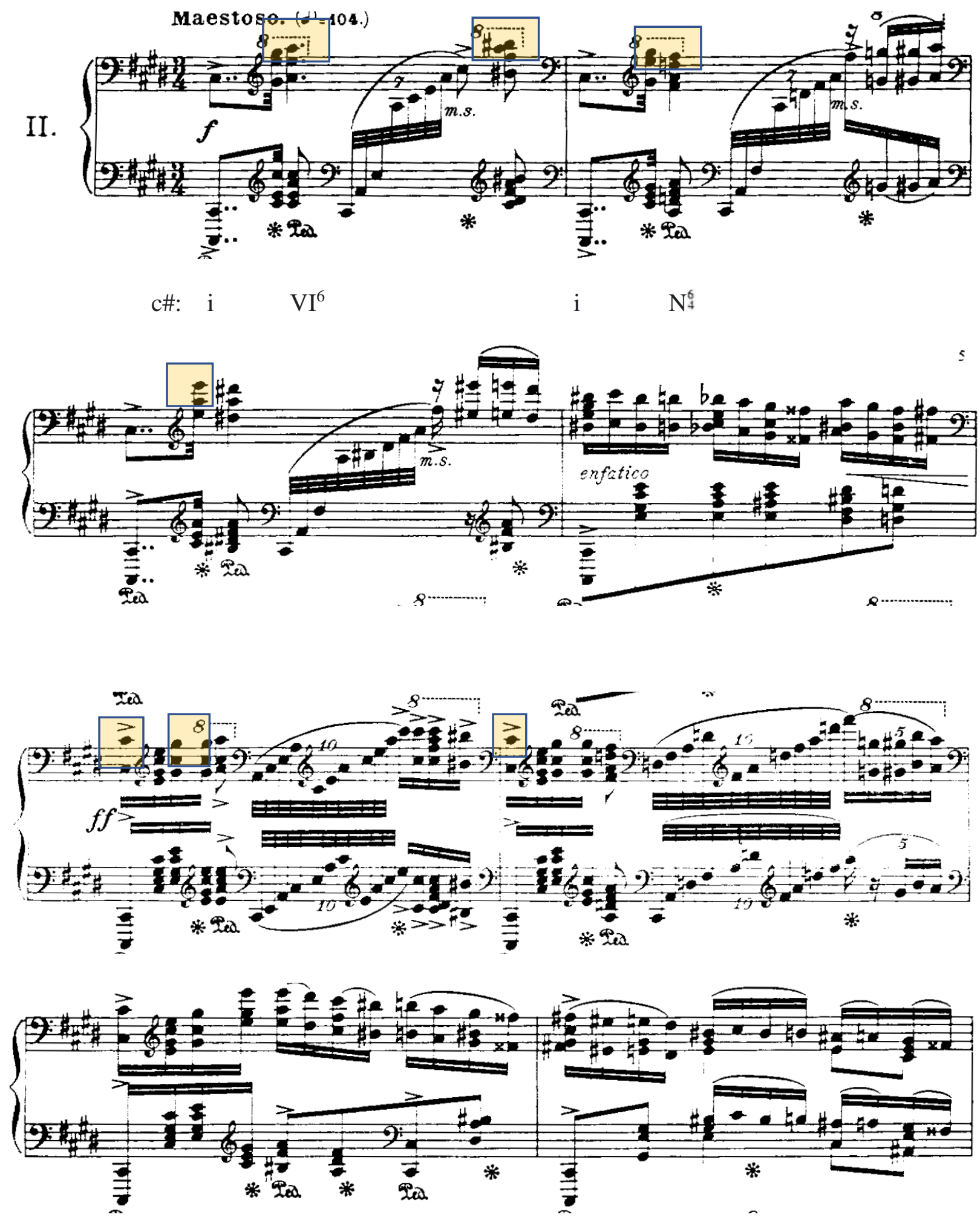

Figure 5.3. Var. II, mm. 1 -8. 
Beach's use of a broad range of the keyboard, fast $32^{\text {nd }}$-note figures, octaves, and large leaps give this variation an orchestral effect.

Unlike the theme and Variation I, which end softly, this variation concludes heavily with octaves. Beach uses a fermata on the rest at the end to prepare for the change of mood in Variation III (see Figure 5.4).
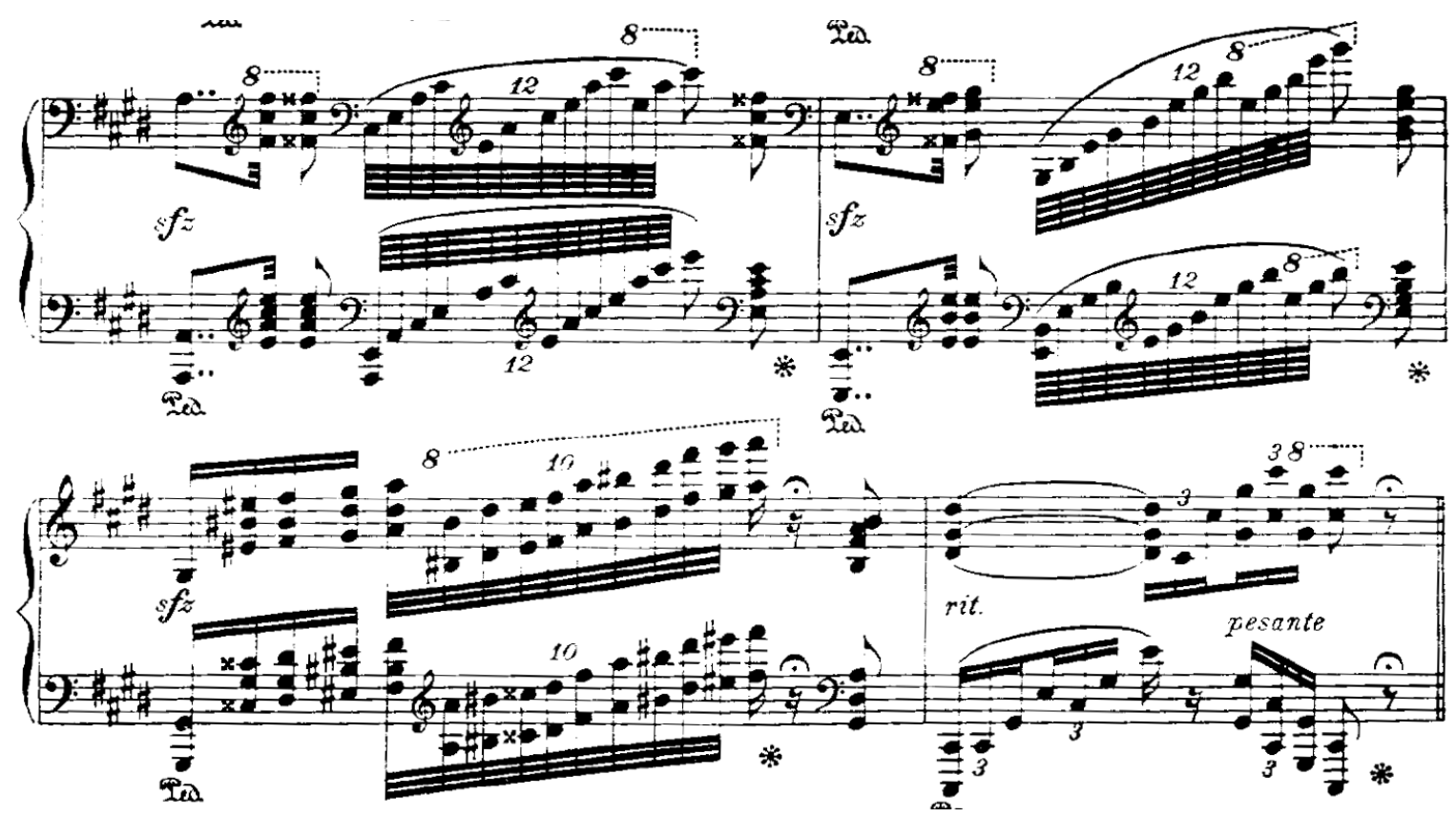

Figure 5.4. Var. II, mm. $17-20$.

\section{Variation III}

In Variation III, Beach continues with the virtuosic writing. The right hand writing is

reminiscent of typical $19^{\text {th }}$-century pianistic figures, such as those found in Saint-Saëns's Piano Concerto No. 2. Here, Beach hides the "O Maiko Moya" theme in the constant staccato $16^{\text {th }}$ notes. This variation has a light and mischievous character. It is the first variation in which Beach essentially highlights the binary form of the theme by providing repeat signs (see Figure 5.5). 

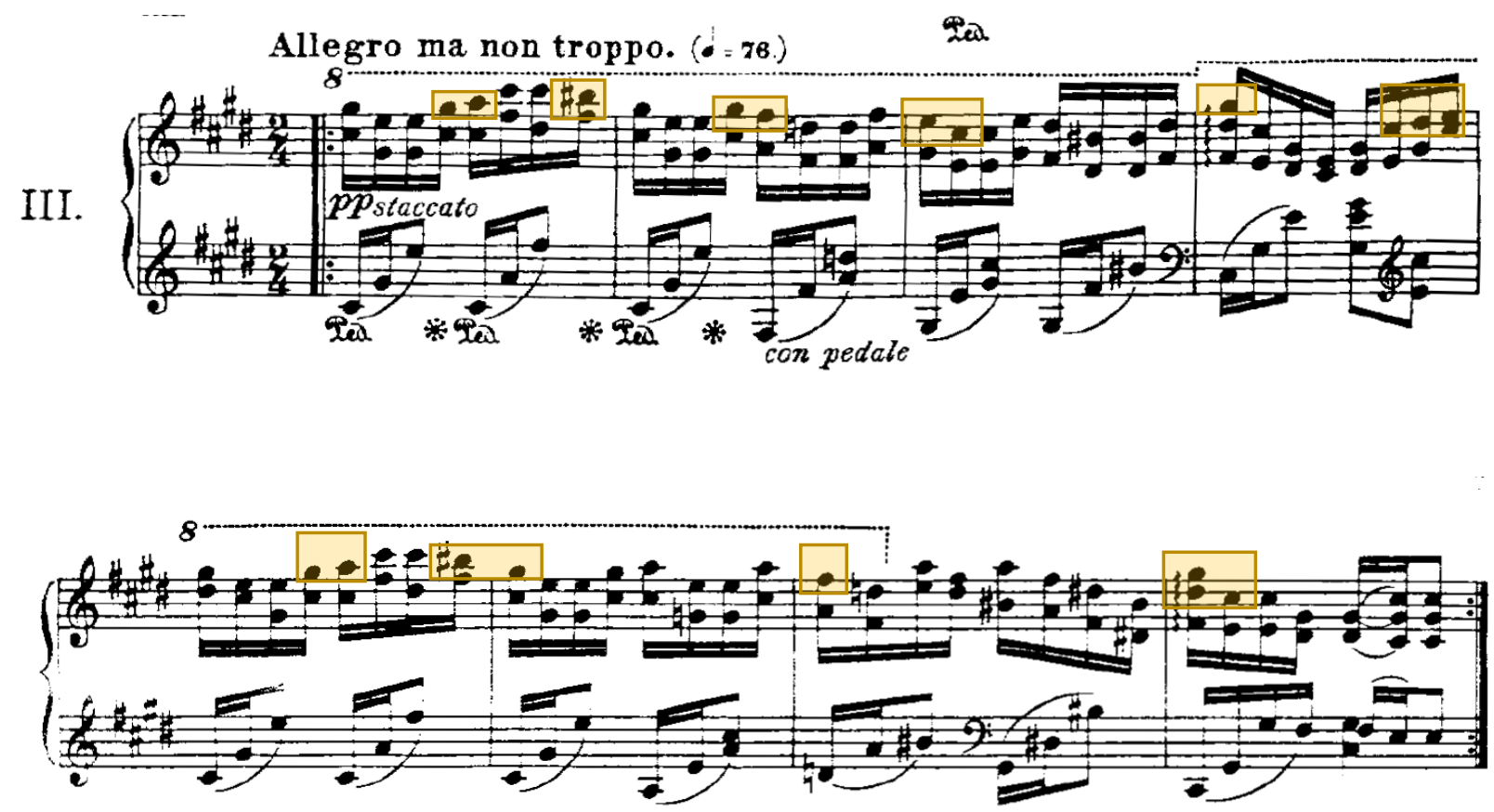

Figure 5.5. Var. III, mm. $1-8$.

Variation III is slightly longer than the previous variations and the theme. Beach extends the coda to eight measures. In this extended coda, she combines the "O Maiko Moya" three-note motive into the virtuosic passage in measure 23 and 24. At the same time, the left hand imitates the right-hand passage. She ends this variation with a C\# major chord. This Picardy-third effect gives a "sense of finality to this initial section" and sets "the stage for the expansion that will take place immediately after." ${ }^{83}$ Variation III is the last variation that begins with C\# minor. From Variation IV onward, every variation starts with a different key. Beach uses a keysignature change at the end of variation III, which signals the new starting key in Variation IV (see Figure 5.6).

\footnotetext{
${ }^{83}$ E. Douglas Bomberger, "Motivic Development in Amy Beach's Variations on Balkan Themes, Op. 60," American Music 10, No. 3 (1992): 333.
} 

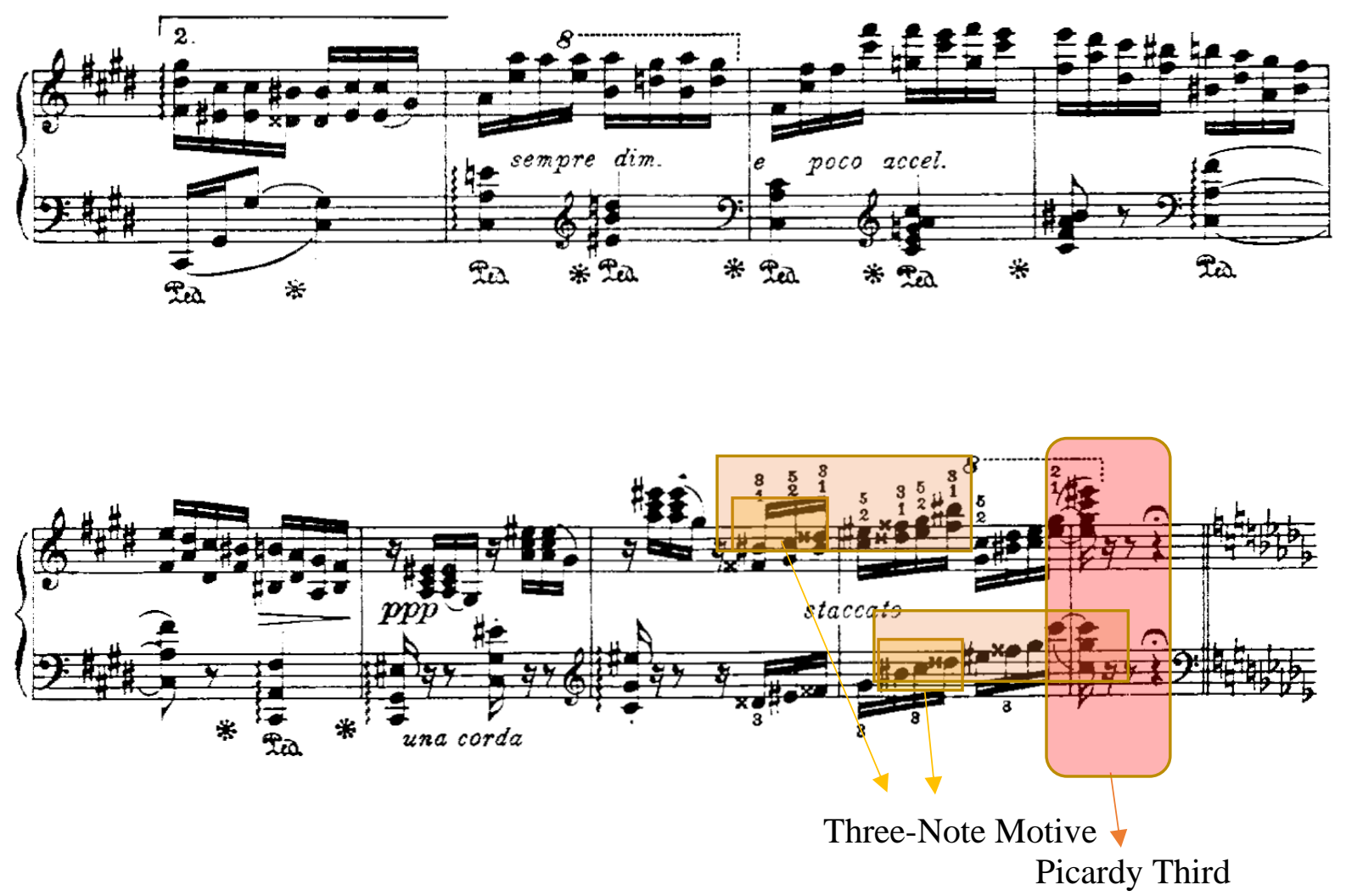

Figure 5.6. Var. III, mm. $17-25$.

\section{Variation IV}

Variation IV is a Barcarolle and begins in $\mathrm{Bb}$ minor. It is the first variation that does not start in $\mathrm{C \#}$ minor. Though $\mathrm{Bb}$ minor is a remote key, its relative major $\mathrm{Db}$ is the parallel key of C\# minor. The form of this variation is still binary but repeating only the B section. Beach's use of a deceptive cadence in $\mathrm{m} .4$ and a striking modulation to D minor in $\mathrm{m} .9$ are highlights of this variation. Concealing the "O Maiko Moya" three-note motive with complex harmonies of the B section is another interesting aspect of this variation. In $\mathrm{m} .9$, the fast scale in the right hand is in D natural minor. No folk motive appears in this measure. In m. 10, Beach uses D harmonic minor in the fast scale, and hides the motive there. The motive appears once every octave. In $\mathrm{m}$. 11, the motive appears twice in each octave. Hence, the motive becomes more and more clear as the variation evolves (see Figure 5.7). 

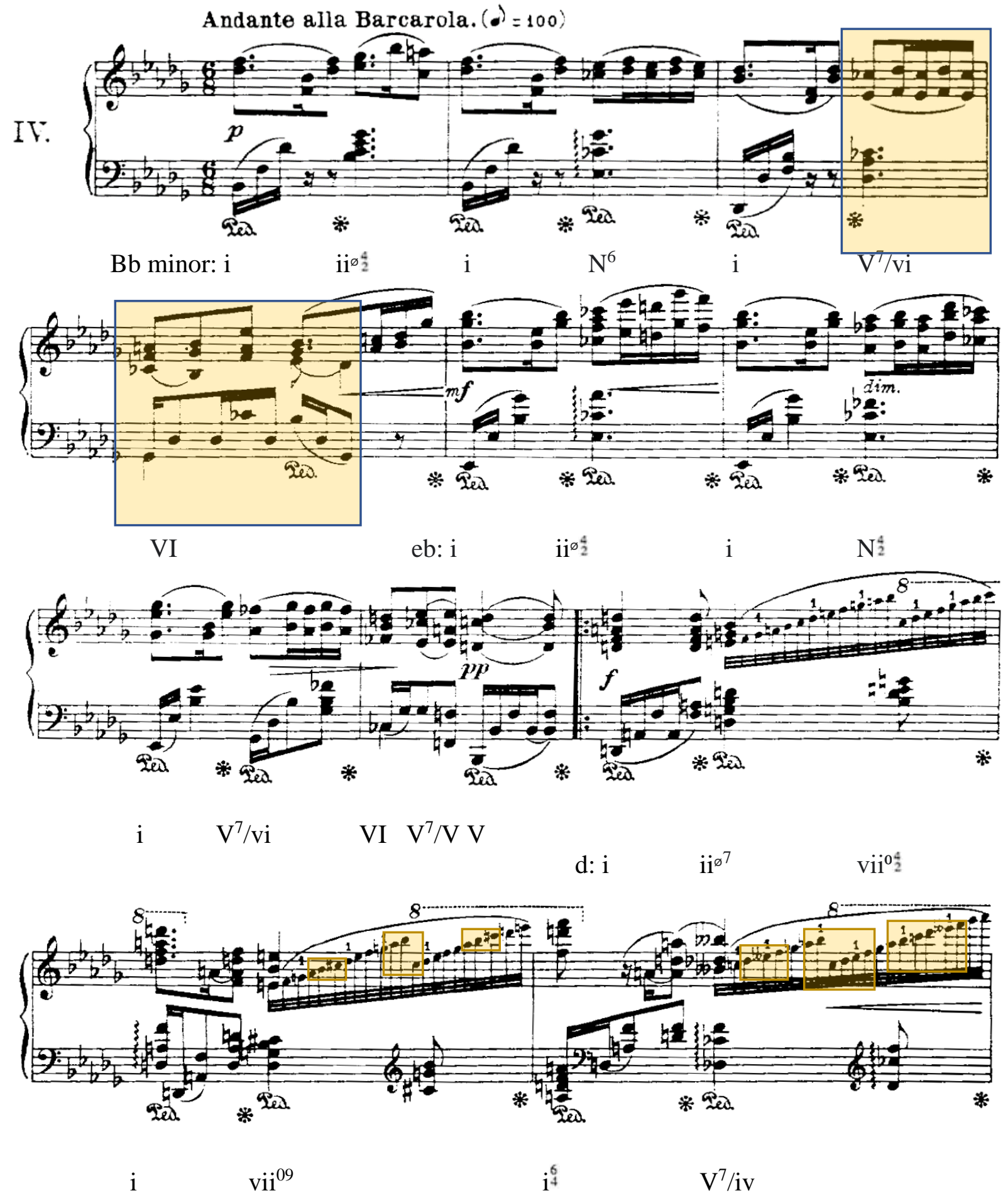

Figure 5.7. Var. IV, mm. 1 - 11. 
Beach uses a flowing left-hand accompaniment pattern which helps to create the barcarolle effect in the A section. In the B section, she applies fast scales, a striking key change and complex harmonies to make the contrasting section more dramatic. The coda of this variation is four measures long and Beach returns to the original echo effect with a quiet dynamic. The variation ends with silence, without going directly to Variation V (see Figure 5.8).

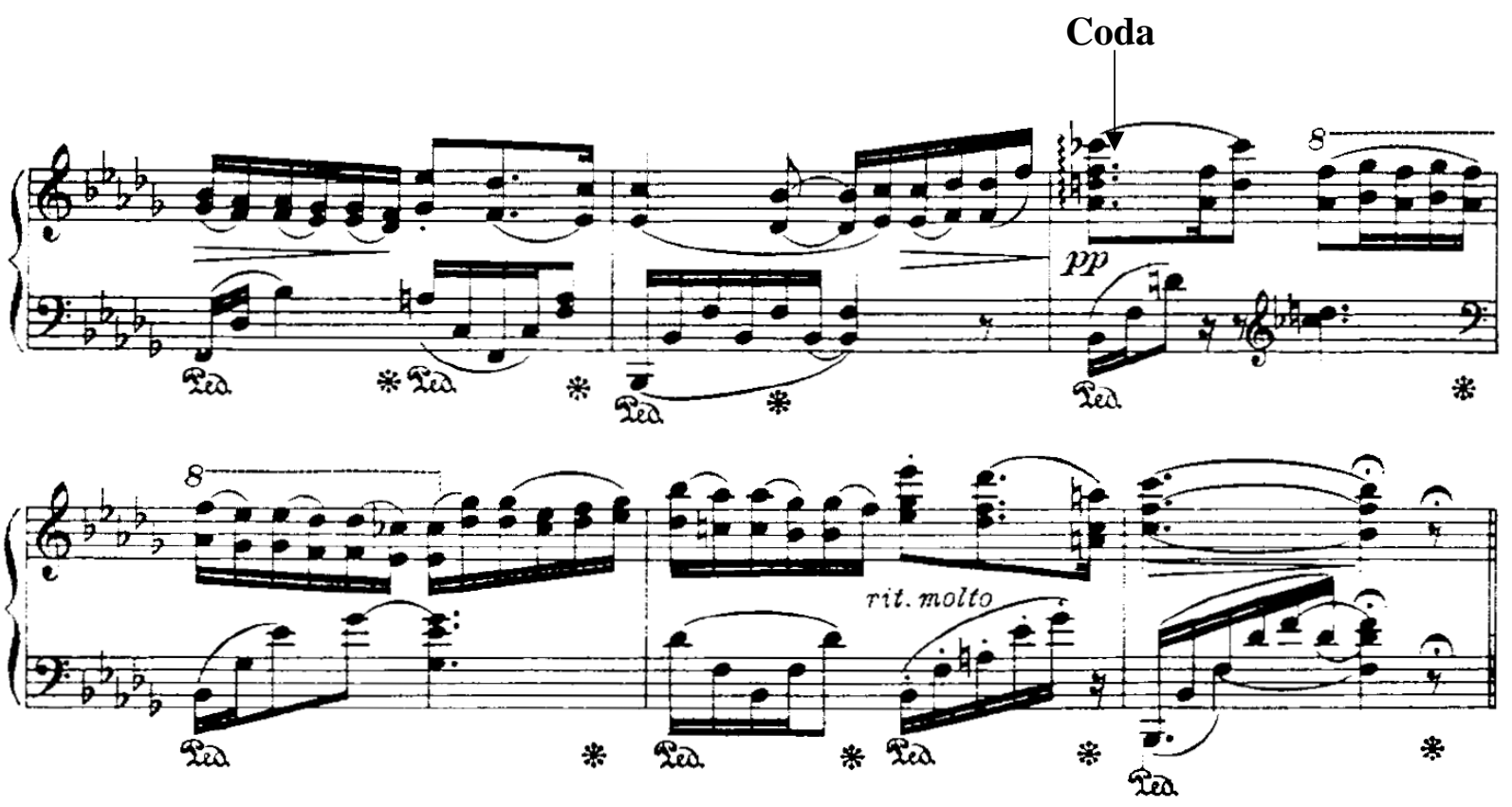

Figure 5.8. Var. IV, mm. $18-22$.

\section{Variation V}

Variation $\mathrm{V}$ is the first variation with a slow introduction. Beach's pianistic figures are particularly interesting here, as most of this variation is for the left hand alone. Beach uses parallel $6^{\text {th }}$ chords as the variation starts and varies the melody to begin on a pickup note. It is also the first variation which Beach uses the "O Maiko Moya" theme in a major key, Gb, with a sweet, singing, and expressive character. Because of the major key, in m. 3 Beach manipulates the "O Maiko Moya" three-note motivic melody with a major third instead of an augmented $2^{\text {nd }}$. The first 9 measures are played by the left hand alone, also revealing an example of Beach's use 
of the late Romantic keyboard style of multiple rolled chords. From m. 6, Beach uses three staves, and right hand enters in m. 10 with the "O Maiko Moya" three-note motive. For these three staves, the right hand only plays top line trills and filigree, while the bottom two staves are played by the left hand (see Figure 5.9).
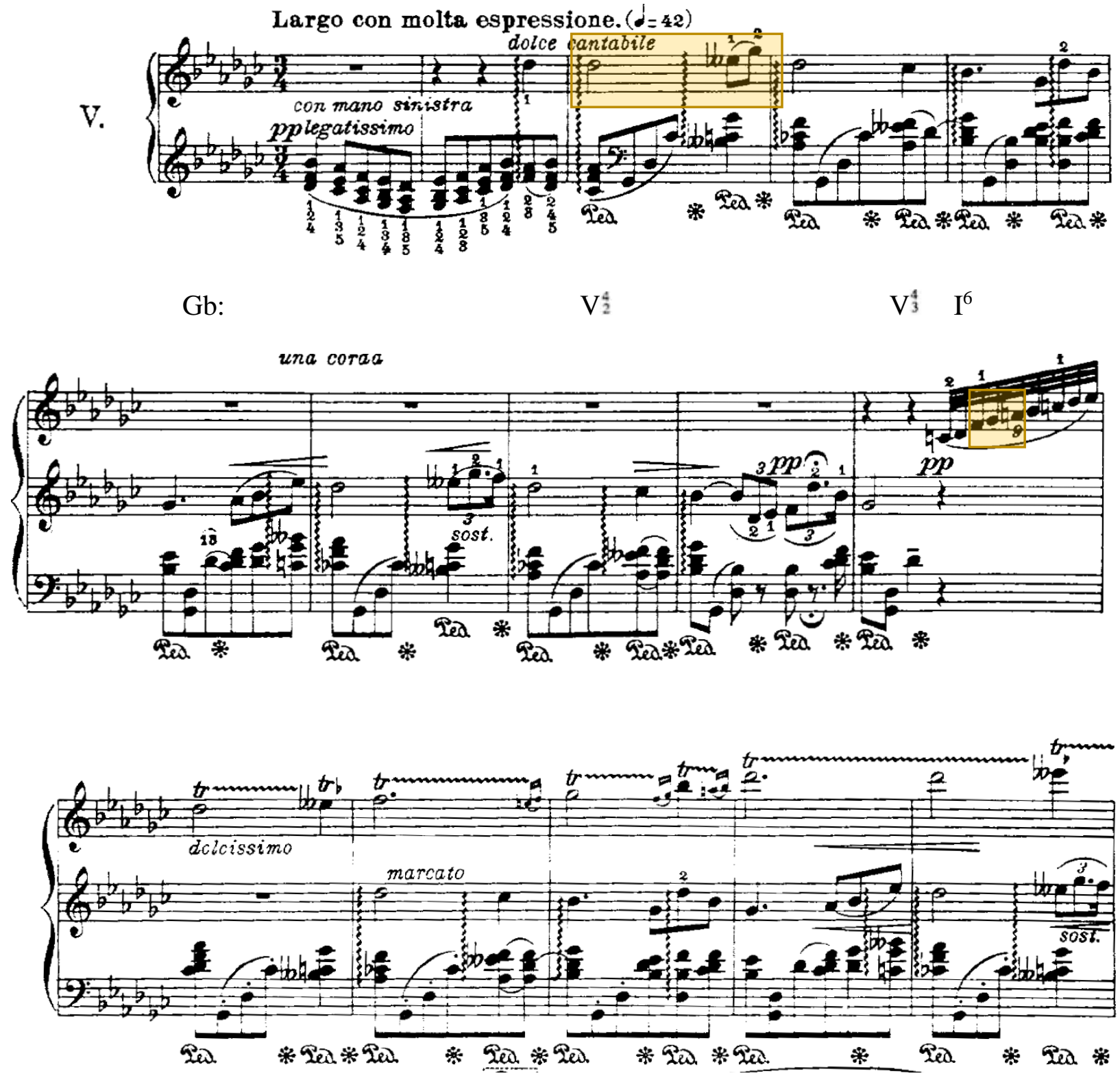

Figure 5.9. Var. V, mm. $1-15$.

This variation is clearly divided into two principal sections: the "Largo con molta espressione" in Gb major and "poco più mosso" in Eb minor. It is longer than all the previous 
variations and contains 39 measures. It is the first variation that contains a significant tempo change. The "poco più mosso" section also starts with the left hand alone; the right hand does not come in until the scale and trills. Unlike the expressive and sweet opening Gb-major section, this Eb-minor section is more dramatic and passionate (see Figure 5.10).
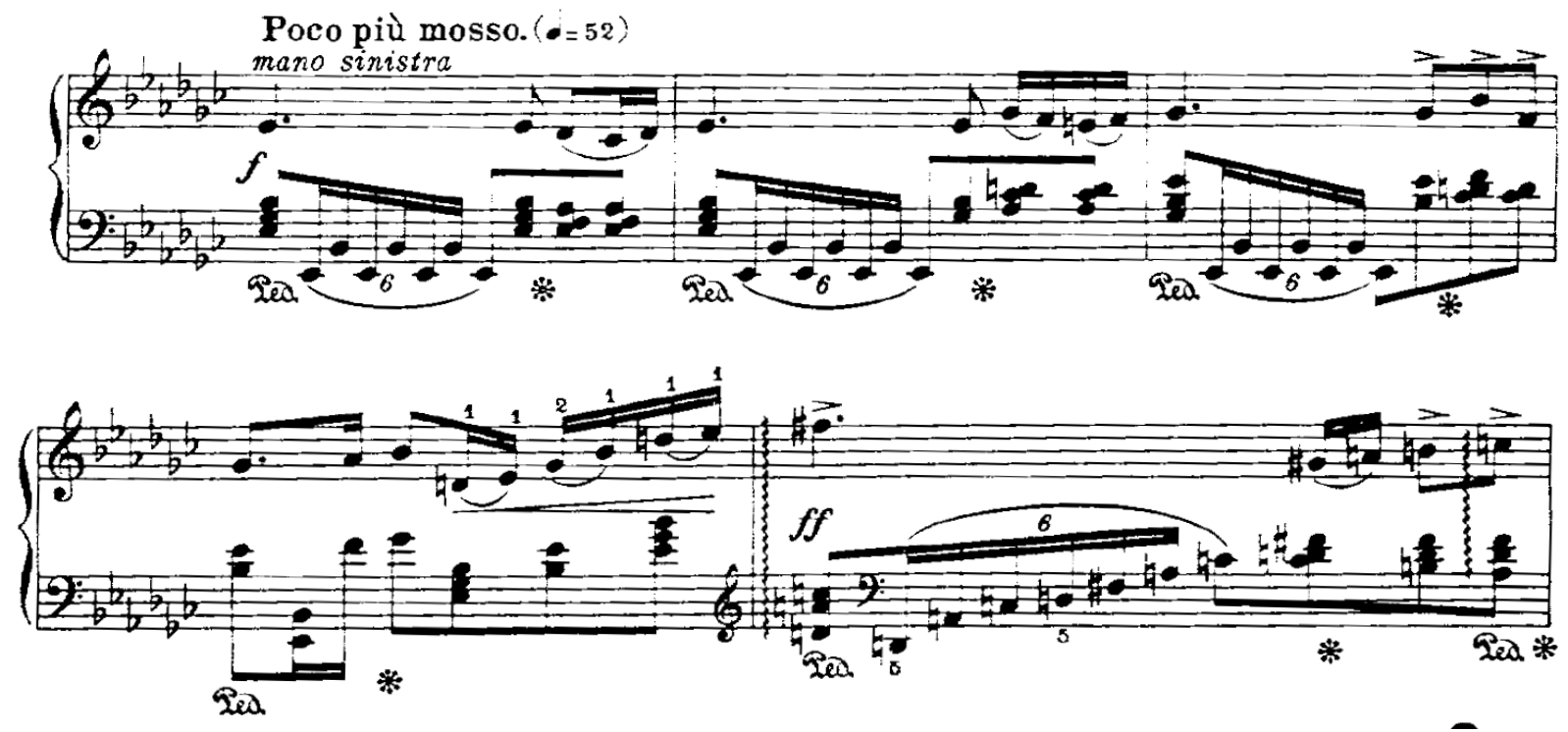

Figure 5.10. Var. V, mm. $19-23$.

Beach uses a slow tempo for this variation, which facilitates playing so much of the material with the left hand alone. Being able to navigate the leaps and bring out the melody by the left hand alone demands a strong pianistic technique. The last five measures are the only place that Beach uses the traditional right and left hand on two staves in this variation. In m. 38 , the rapid descending double thirds are written for right hand alone but could be done twohanded if needed. This variation is a testament to Beach's formidable piano technique and exploits another aspect of keyboard virtuosity. The variation ends with an unresolved vii $0_{2}^{4}$ chord which leads into Variation VI (see Figure 5.11). 

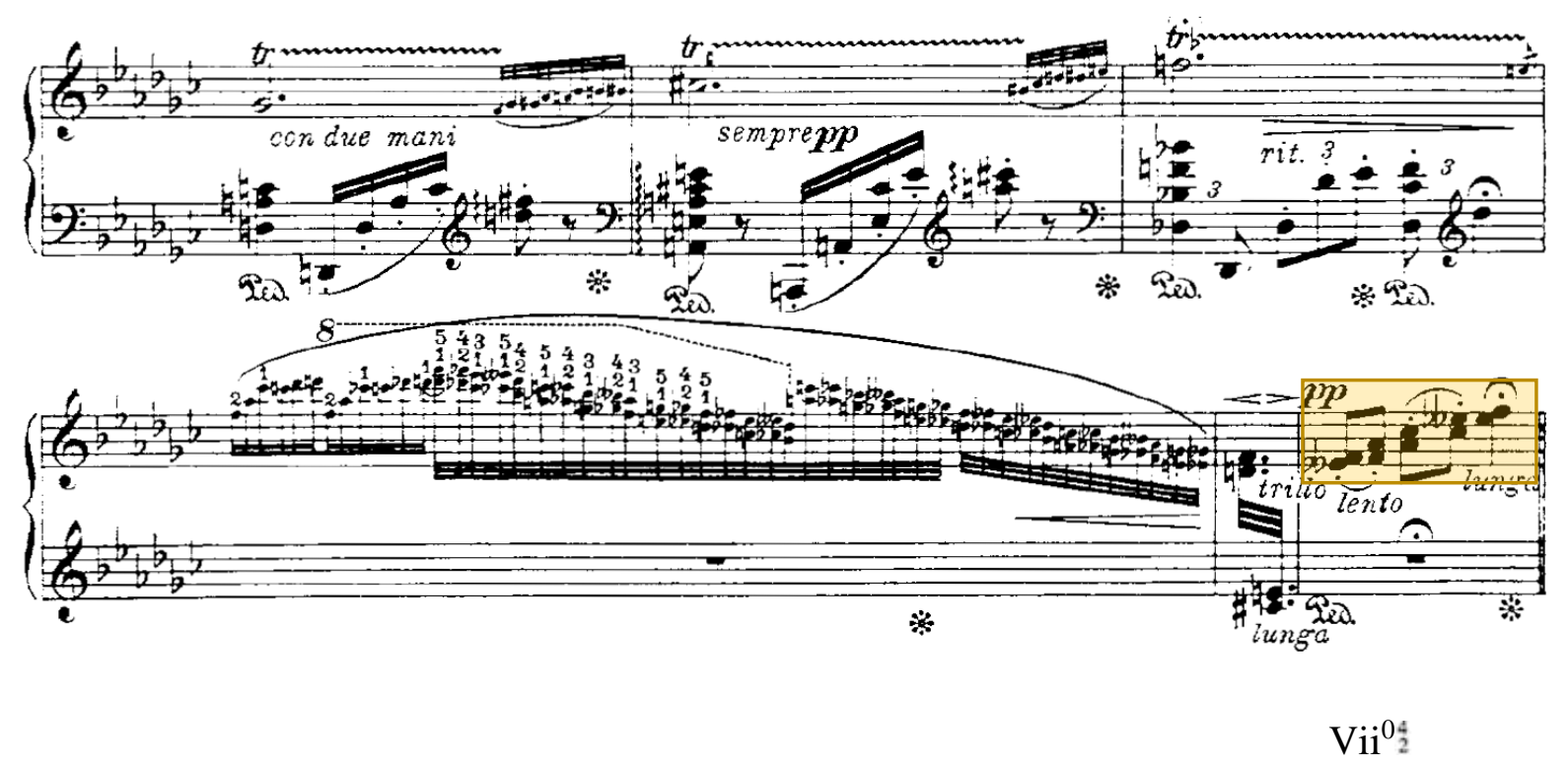

Figure 5.11. Var. V, mm. $35-39$.

\section{Variation VI}

Variation VI shows Beach's use of the fantasy element. It is the most extended variation so far and is comprised by a slow introduction and a fast-Hungarian dance. Beach uses a new theme, the "Stara Planina" melody, which is "an ancient hymn to the mountains." introduction section possesses a fantasy-like character in which Beach uses an interesting change of meters, improvisatory rolled chords and sustained harmonies (see Figure 5.12).

${ }^{84}$ Amy Beach, "Variations on Balkan Themes, Op. 60," in Amy Beach Piano Music, ed. by Sylvia Glickman (New York: Da Capo Press, Inc., 1982), introduction. 

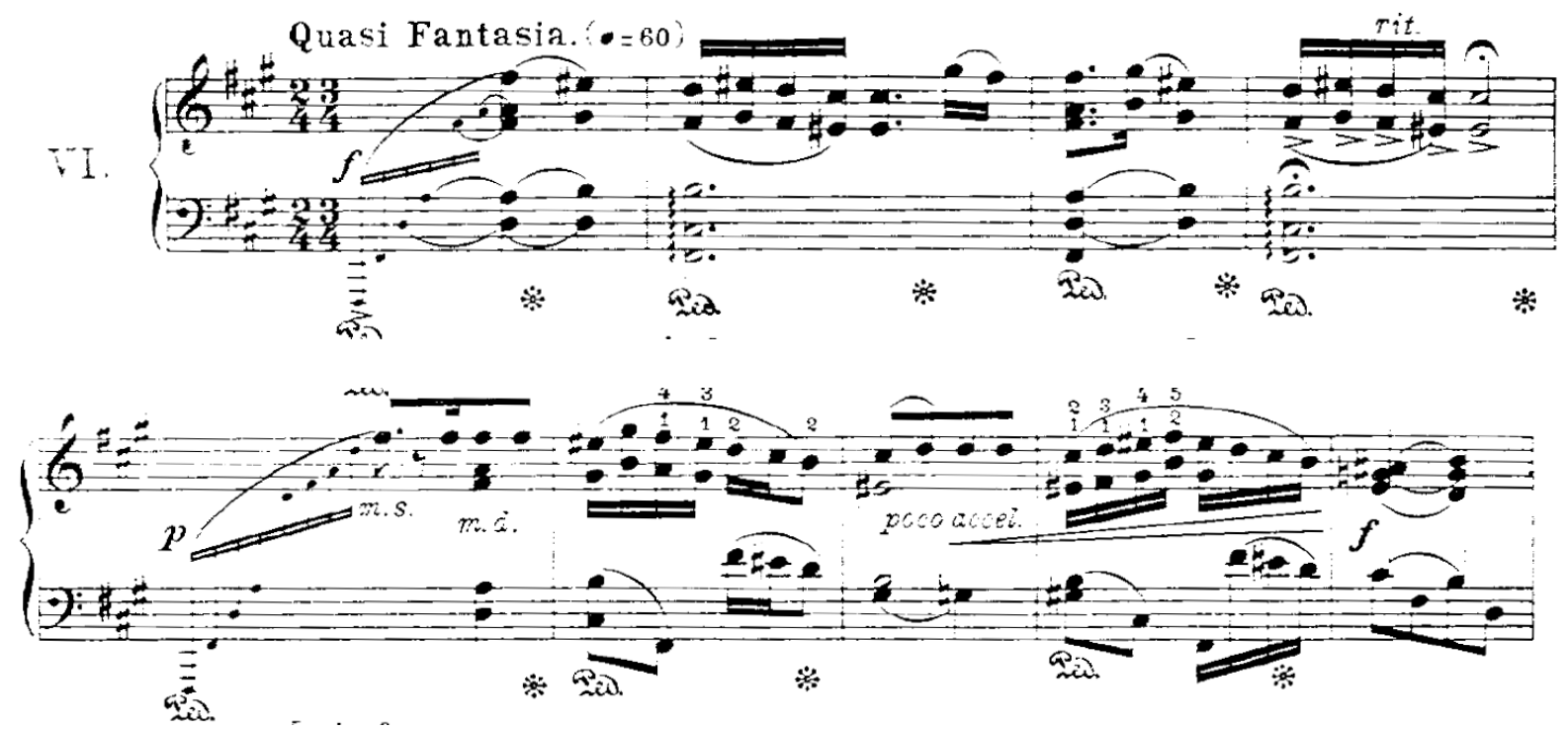

Figure 5.12. Var. VI, mm. $1-4$.

The first three notes of the "Stara Planina" theme reveal a transposed inversion of the initial three-note motive of the "O Maiko Moya" theme. Both themes use a minor second and an augmented interval (see Figure 5.13).

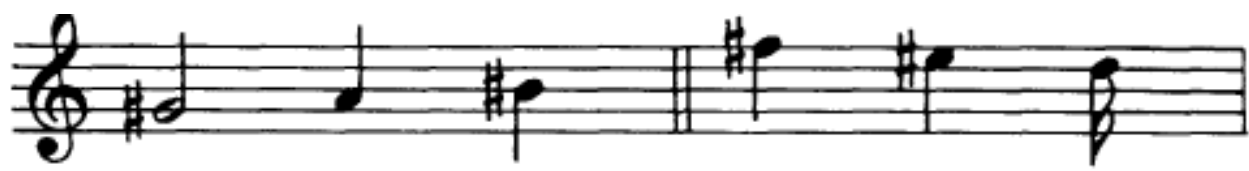

Minor $2^{\text {nd }} \quad$ Aug $2^{\text {nd }} \quad$ Minor $2^{\text {nd }} \quad$ Aug 2nd

Figure 5.13. Initial Three-Note Motives of "O Maiko Moya" and "Stara Planina"

The relationship of these intervals of the "O Maiko Moya" and "Stara Planina" themes gives this variation a connection to the whole. The introduction ends with augmented-second tremolos that further emphasize the motive (see Figure 5.14). 


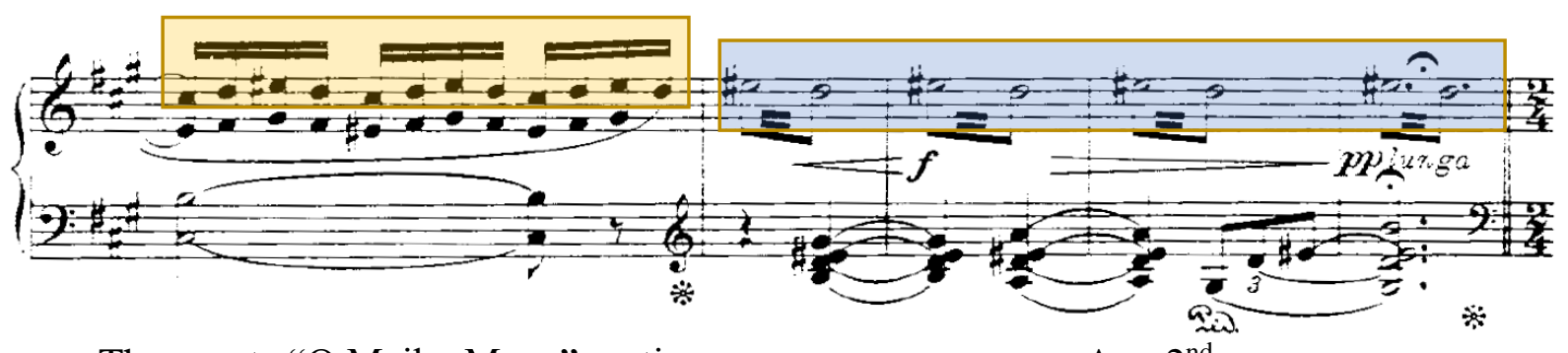

Three-note "O Maiko Moya" motive

Aug $2^{\text {nd }}$

Figure 5.14. Var. VI, mm. $14-18$.

The fast-Hungarian dance section is first heard in F\# minor with the "O Maiko Moya" theme and later in F\# major with the first appearance of another new theme, "Nasadil e Dado."

Beach adds grace notes to the melody and accents on the weak beat to enhance the carefree and flirting character of the gypsy style in the F\# minor section (see Figure 5.15).

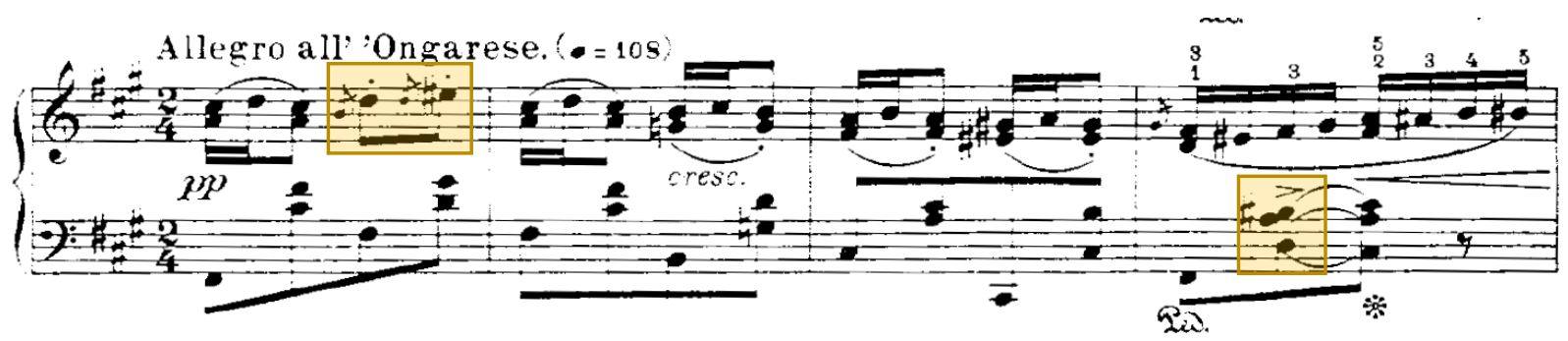

Figure 5.15. Var. VI, mm. $19-22$.

This F\# minor section ends with a half cadence in the left hand and virtuosic chromatic sixths in the right hand (see Figure 5.16).

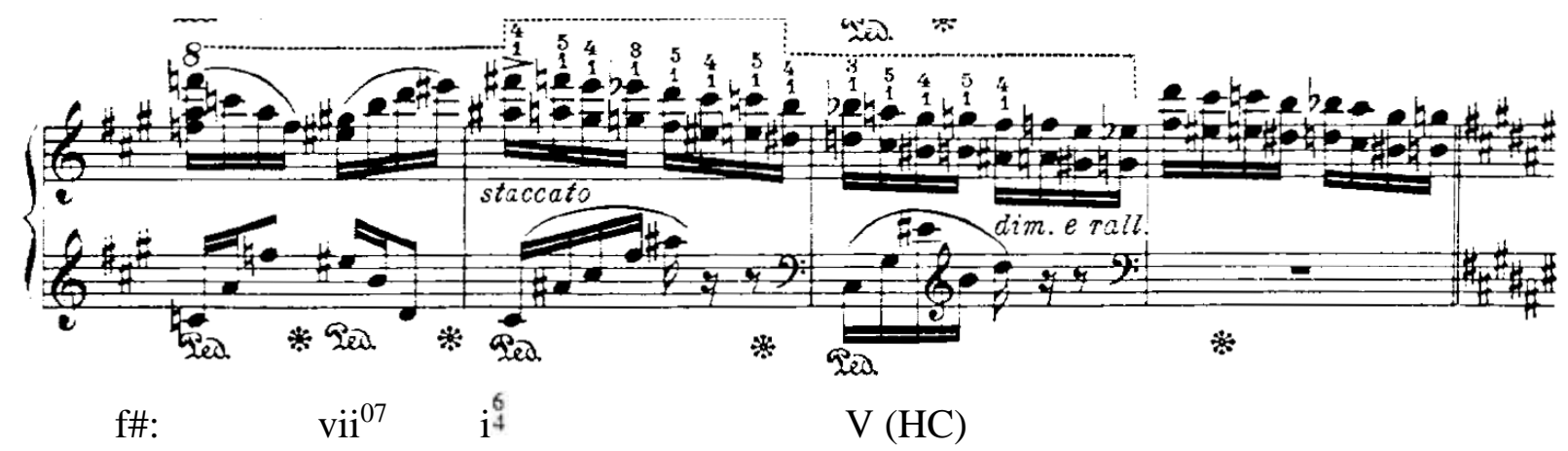

Figure 5.16. Var. VI, mm. $47-50$. 
The F\# major section is light and happy, and the harmony is also very simple. It is the only place that Beach uses the "Nasadil e Dado" theme (see Figure 5.17).

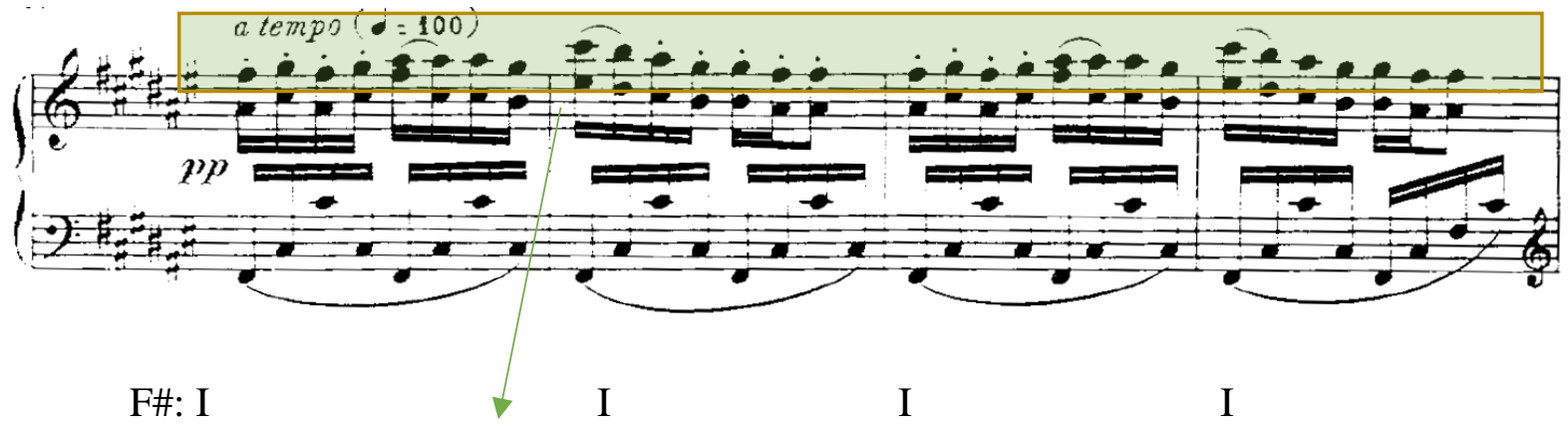

"Nasadil e Dado" theme

Figure 5.17. Var. VI, mm. $51-54$.

Overall, this variation uses Hungarian rhythms and character as Liszt also did in his

Hungarian Rhapsodies. The form is known as the "classic lassu-friss of the Hungarian

Verbunkos." ${ }^{85}$ Verbunkos is "a traditional Hungarian dance music originally used for recruiting, of $18^{\text {th }}$-century origin and sometimes simply called a hongroise, or ungarischer Tanz." 86 During the recruiting, the sergeant would dance first with "slow and dignified figures," then the "subordinate officers would join in and the music and dancing became increasingly energetic, until finally the youngest soldiers engaged in virtuosic leaps and spur-clicking. The accompanying music was usually played by Gypsy musicians." ${ }^{97}$ At the end of this variation, Beach marks "poco a poco più mosso" in the music. Beach must have been familiar with this dance form as this variation follows the form closely. The "Tempo I" at the last measure is reminiscent of the opening fantasy character (see Figure 5.18).

\footnotetext{
${ }^{85}$ E. Douglas Bomberger, "Motivic Development in Amy Beach's Variations on Balkan Themes, Op. 60," American Music 10, No. 3 (1992): 337.

86 Jonathan Bellman, "Verbunkos," Grove Music Online, 2001, Accessed 11 Oct. 2020, https://www.oxfordmusiconline.com/grovemusic/view/10.1093/gmo/9781561592630.001.0001/omo$9781561592630-\mathrm{e}-0000029184$.

87 Ibid.
} 

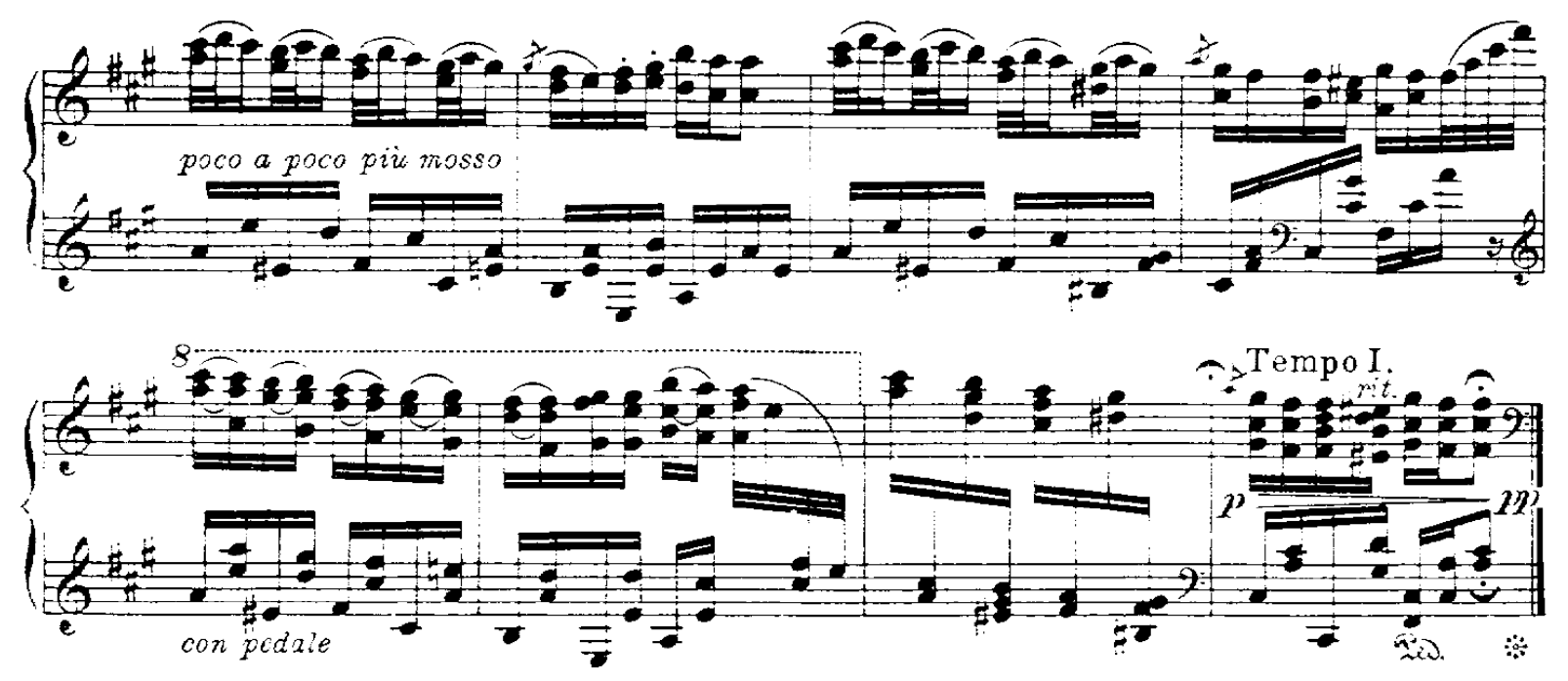

Figure 5.18. Var. VI, mm. $75-82$.

Virtuosic thirds, sixths in the right hand, large leaps, staccato octaves, octaves with added notes, and chromatic passages are the pianistic devices that Beach applies in this variation. It is a miniature of Liszt's Hungarian rhapsodies in style.

At this point, the music no longer follows the form of the "O Maiko Moya" theme as in the first three variations. Starting from variation IV, the striking key shifts and frequent harmonic changes makes the proceeding variations become more surprising and interesting. Variation $\mathrm{V}$ further departs from the form by utilizing remote key (Gb Major) and separates the variation into two parts with tempo changes. In Variation VI, Beach uses the Hungarian dance "lassu-friss" form and applies three Balkan themes. All these structural treatments are Beach's way of showing the fantasy-like aspect of this piece. The principal theme "O Maiko Moya" is treated differently in every variation; nevertheless, the frequent appearances of the motive can always remind listeners of the principal motive.

\section{Variation VII}

Beach begins Variation VII with a three-measure long "Vivace" introduction using an ambiguous tonality between $\mathrm{C} \#$ minor and $\mathrm{E}$ major. The opening ambiguity in tonality of this 
variation is similar to Variation V with the use of parallel sixth chords. In Variation VII, the extra E\# creates the confusion of the key. However, the opening three notes are the intervals of the minor $2^{\text {nd }}$ and major $3^{\text {rd }}$. The last time listeners clearly heard this intervallic relationship is at the opening melody of Variation V. Hence, this is Beach's way of showing the three-note motive of "O Maiko Moya" theme in a major key. As in Variation V, Beach uses "O Maiko Moya" in a major key for Variation VII

Despite the fast introduction, Variation VII is actually a slow, sad waltz in which Beach wanders through different keys by using secondary dominant chords. The waltz is very similar to many of the $19^{\text {th }}$-century waltzes in style such as those by Chopin. Beach uses a binary form here. The A section is in E major, and it corresponds to the first eight measures of the main theme. Beach uses parallel $6^{\text {ths }}$ in the right-hand melody and large leaps in the left-hand accompaniment (see Figure 5.19).

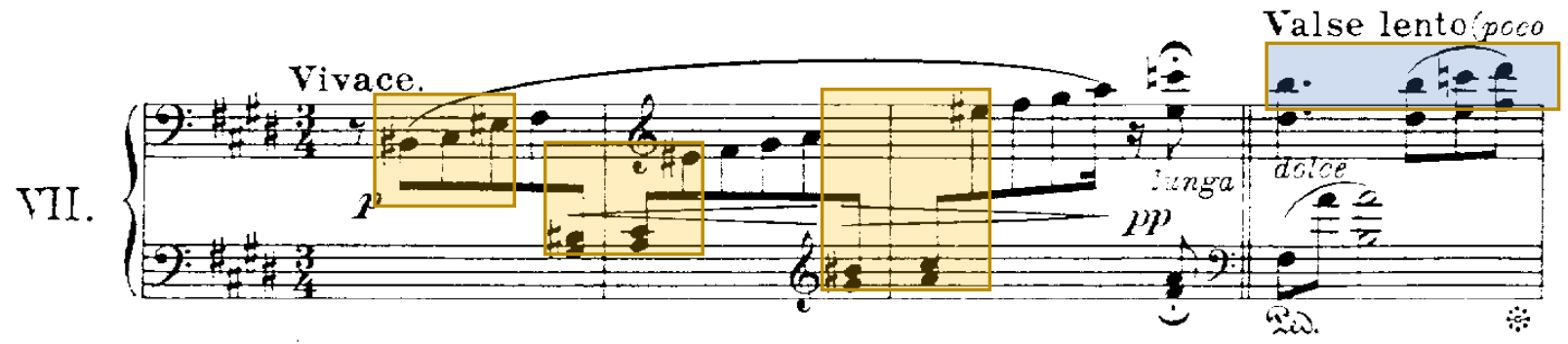

$+6$

E: Three-Note Motive in Major Key (m2 + M3) $\quad$ ii $^{{ }^{7}} \quad \mathrm{~V}^{4} \quad(\mathrm{~m} 2+$ Aug2)

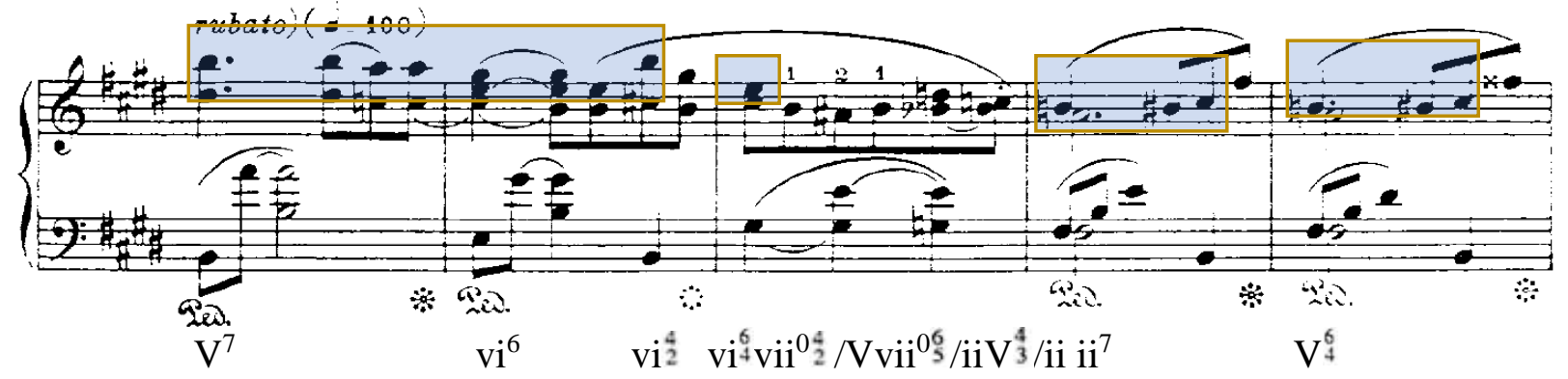

Figure 5.19. Variation VII, mm. $1-9$. 
The B section is in G\# minor, and it is more agitated in character. It correlates to $\mathrm{mm} .9$ through 16 of the main theme but is more complex and has repeats. The texture of the B section is more chordal and chromatic (see Figure 5.20).

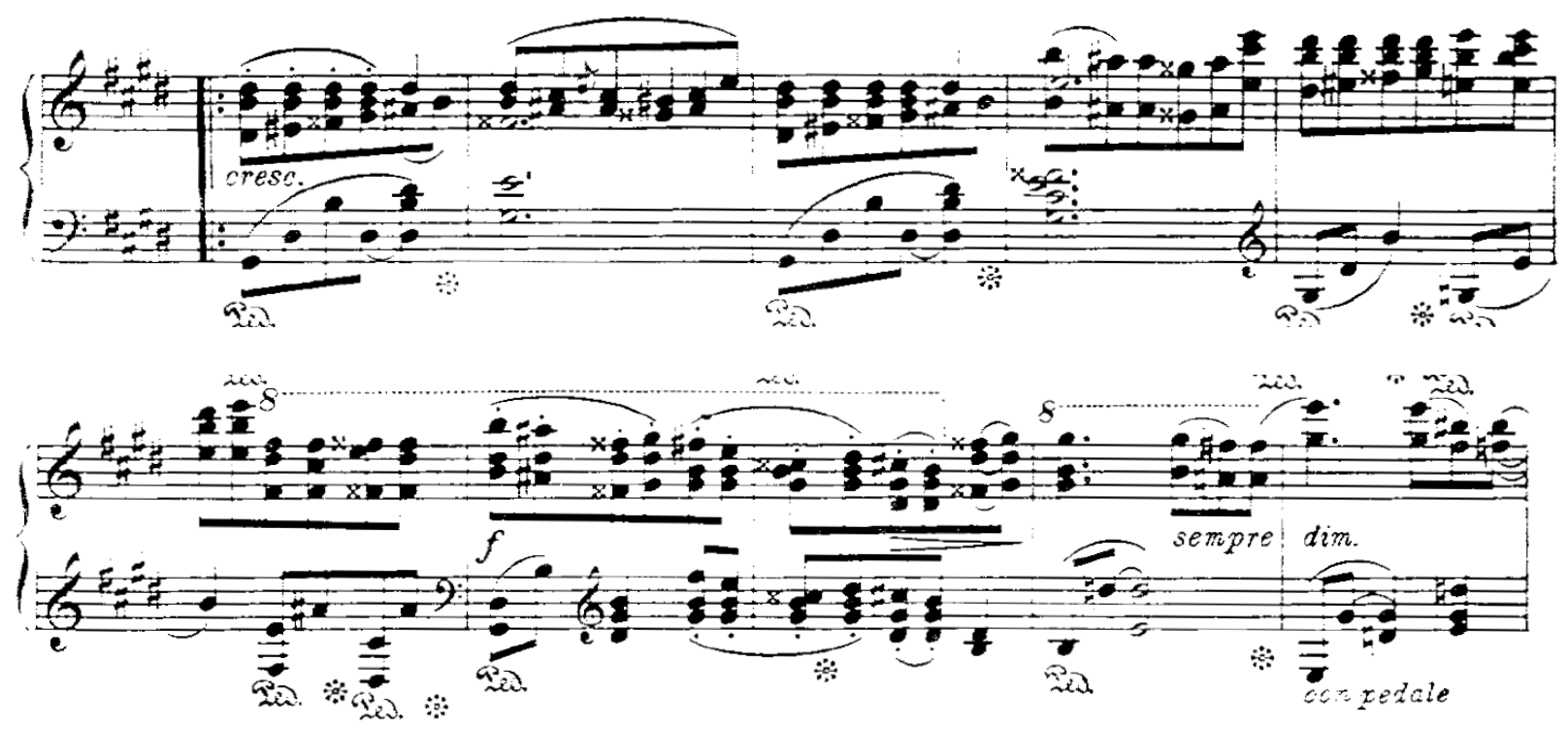

Figure 5.20. Var. VII, mm. $20-29$.

Beach uses a series of secondary dominant chords to prepare the return of E major at the end of this variation. The coda section is extended compared to the original theme. Moreover, The $\mathrm{Ger}^{+6}$ chord in $\mathrm{m} .41$ strengthens the arrival of a final perfect authentic cadence, and the tonic pedal at the end also helps to emphasize the home key of this variation (see Figure 5.21). 


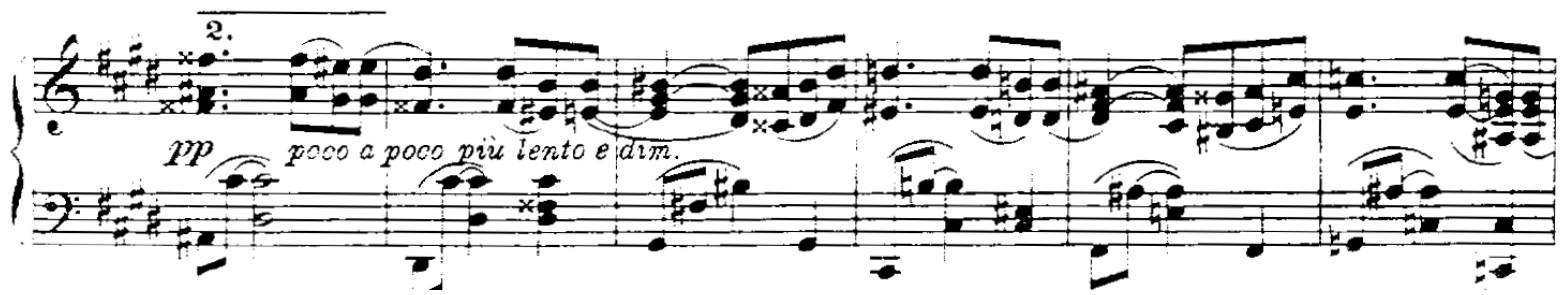

g\#: $\mathrm{V}^{4} \quad \mathrm{~V}^{7} \quad \mathrm{~V}^{7} /$ iv $\quad \mathrm{V}^{7} /$ vii

E: $V^{7} /$ ii

$\mathrm{V}^{7} / \mathrm{V}$

$\mathrm{Ger}^{+6}$

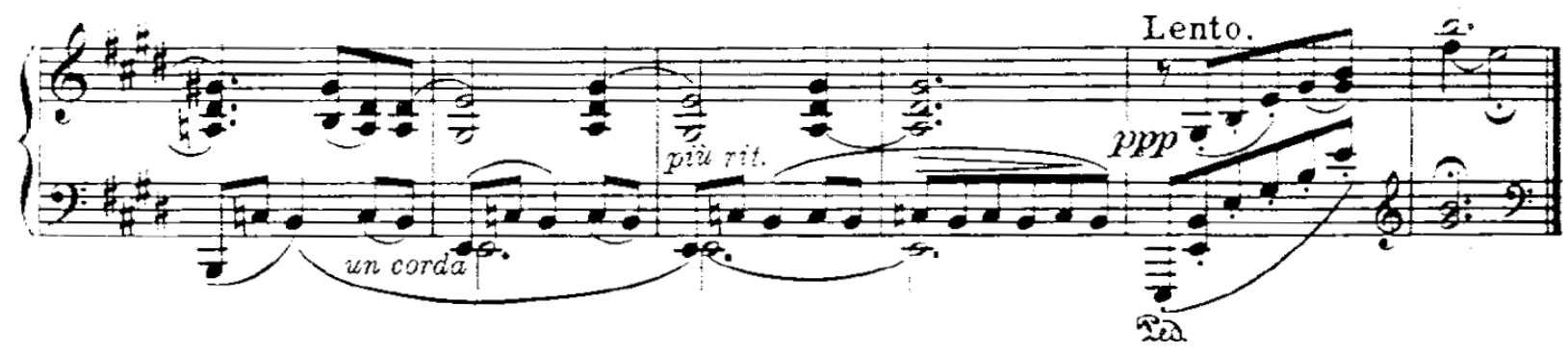

$\mathrm{E}: \mathrm{V}^{7} \quad \mathrm{I}$ (tonic pedal)

Figure 5.21. Var. VII, mm. $36-47$.

Beach slows the ending for this variation with "poco a poco più lento," "più rit." and "lento." All of these markings make this variation a dramatic contrast to the previous variation.

\section{Variation VIII}

Variation VIII is the longest variation of the entire piece. It begins with the fourth Balkan theme - "a centuries-old Macedonian appeal for help made to a neighboring country." " This "Macedonia" theme leads into the funeral march with the "O Maiko Moya" motive. The "Macedonia" theme section is mainly in G\# minor, and it can be further divided into two smaller parts based on the contrasting characters of the melodies. The first part (Con vigore) is very vigorous, and Beach uses sweeping arpeggios to increase the energy of the melody. Beach's use of fermata signs in this part enhances the intensity of the music, especially the fermata sign on

\footnotetext{
${ }^{88}$ Amy Beach, "Variations on Balkan Themes, Op. 60," in Amy Beach Piano Music, ed. by Sylvia Glickman (New York: Da Capo Press, Inc., 1982), introduction.
} 
the rest in $\mathrm{m}$. 7. There is no preparation to modulate from $\mathrm{G \#}$ minor to $\mathrm{C \#}$ major except the fermata on the rest. This fermata on the rest helps to the extend the atmosphere of G\# minor and makes the modulation to $\mathrm{C \#}$ major more dramatic. (see Figure 5.22).

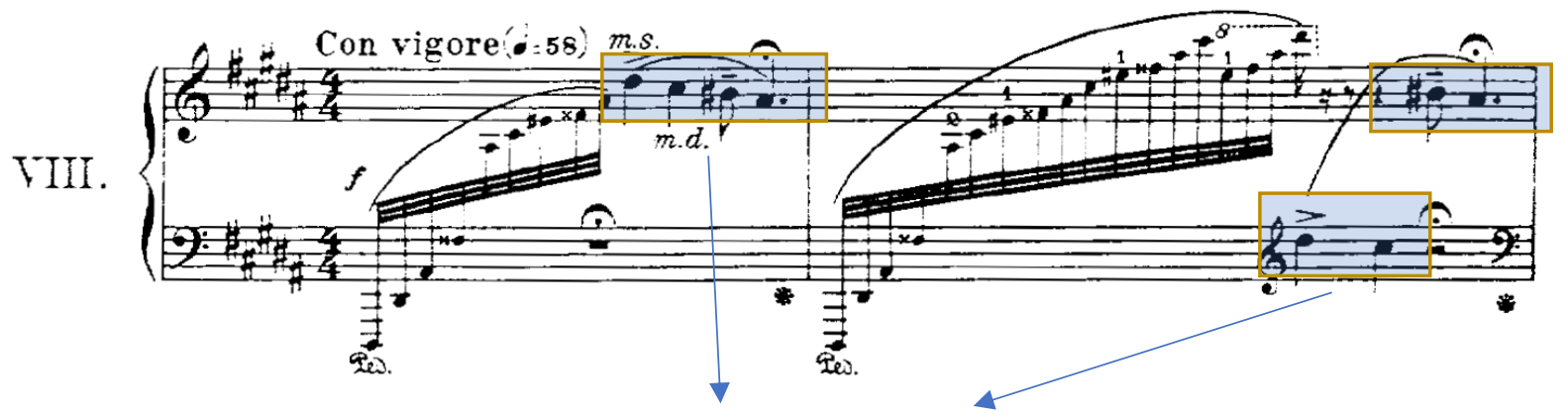

g\#: $\quad \mathrm{V}^{7} \quad$ Macedonia Theme Part I
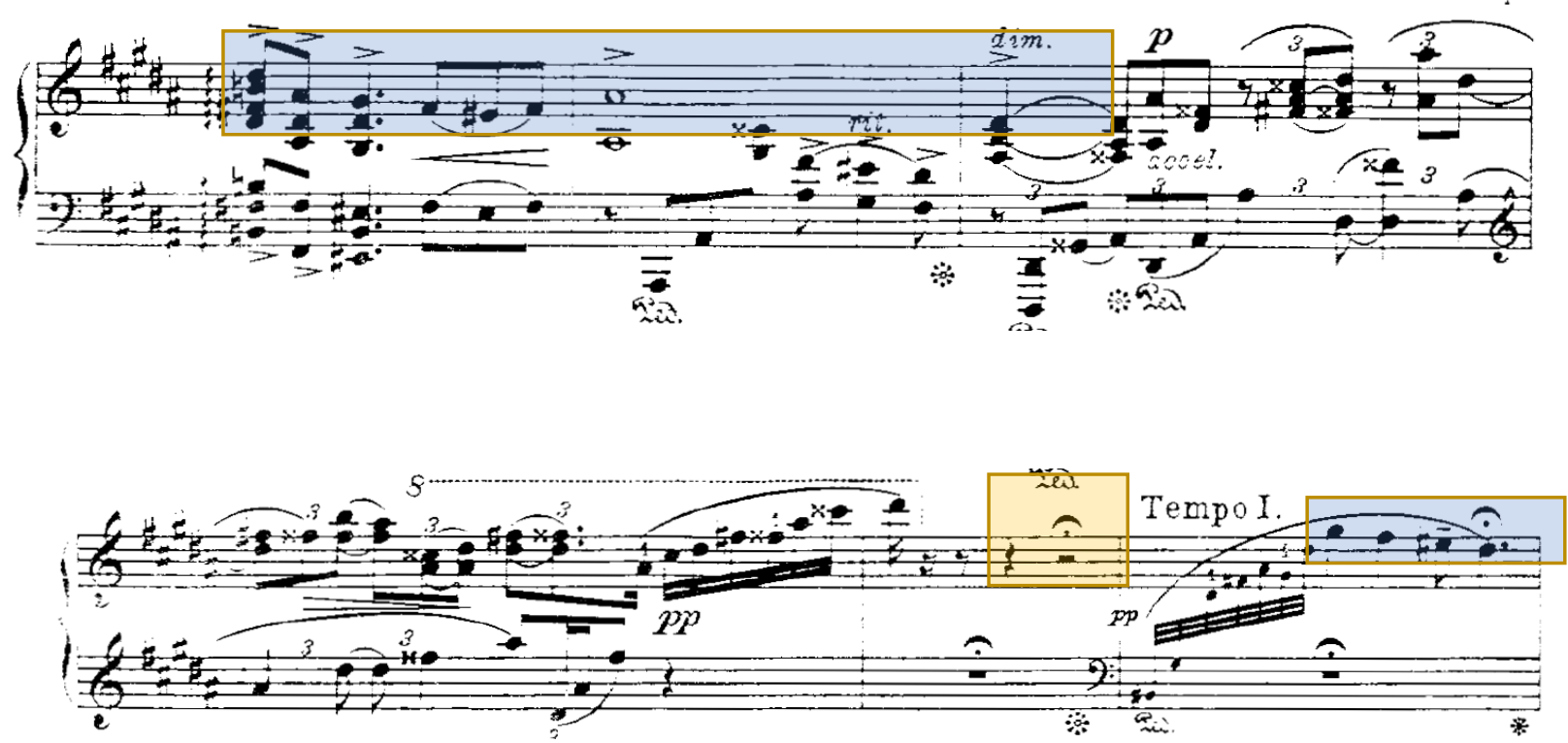
$\mathrm{g \# :} \mathrm{V}^{6}$
$\mathrm{C \#}: \mathrm{V}^{6}$

Figure 5.22. Var. VIII, mm. $1-8$.

The second part (Lento calmato) of this "Macedonia" section is simpler and calmer, but the emotions that the melody carries are very powerful. It expresses well the Macedonian people's cry for help. Beach uses a higher register, expressive melody, and slower tempo to 
make this part a contrast to the Con vigore section. The "Macedonia" theme part I returns at the end of this section and the modulation to E minor leads to the next funeral march section (see Figure 5.23).

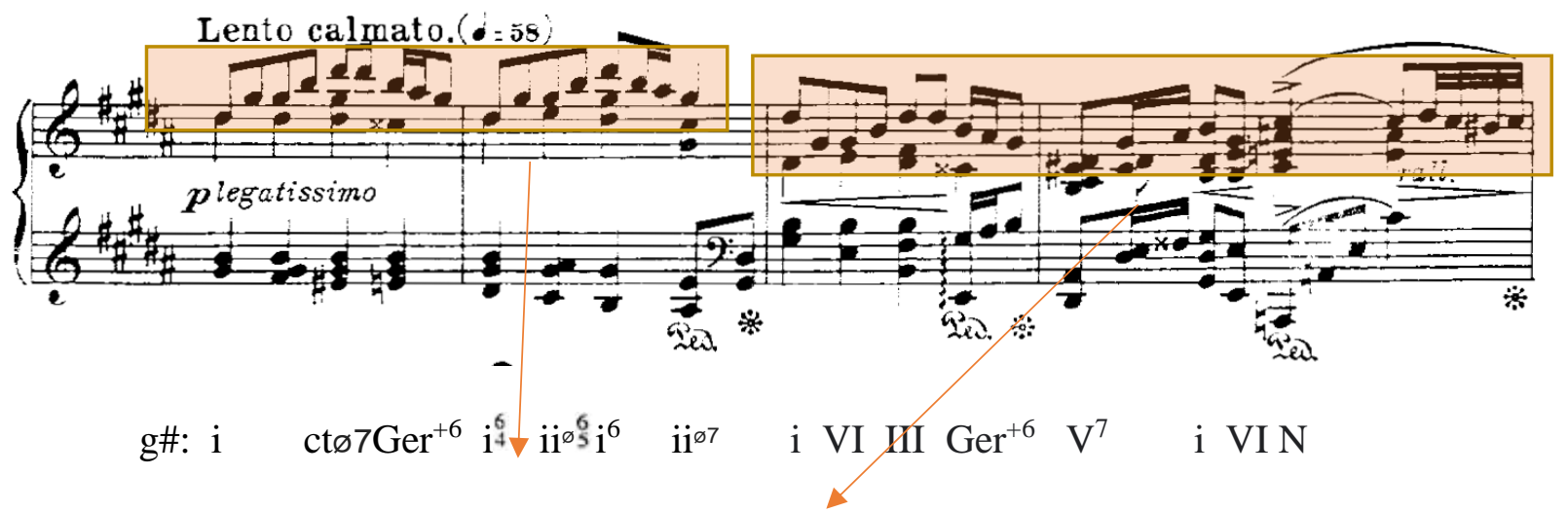

Macedonia Theme Part II

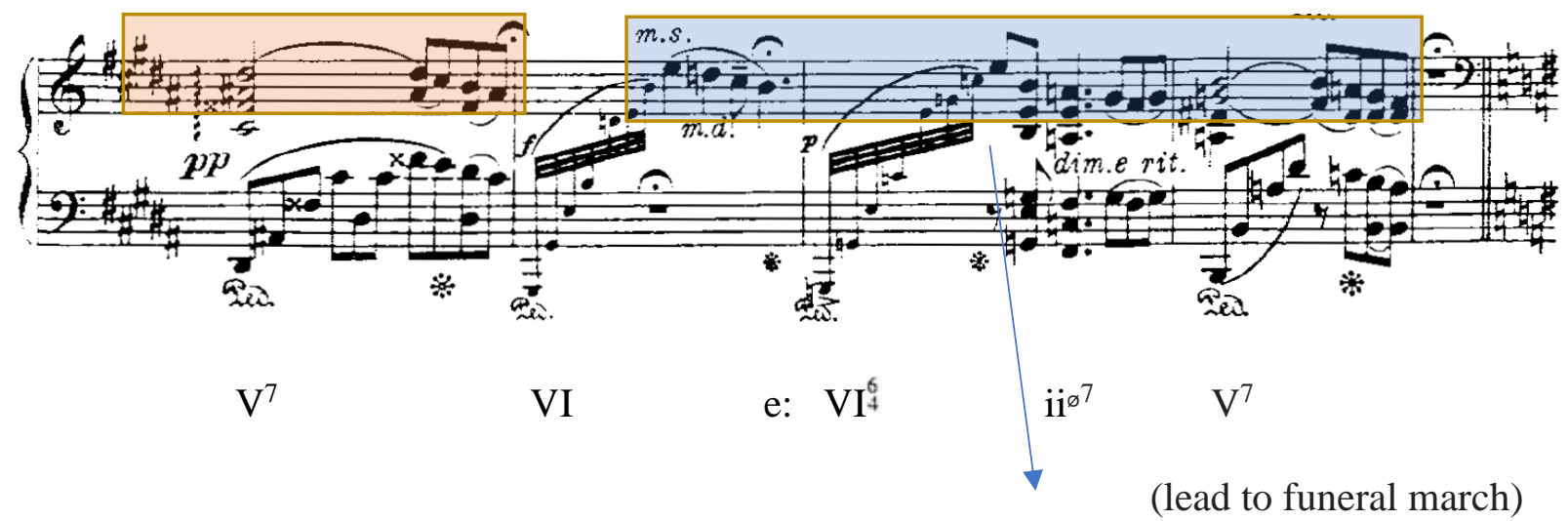

Macedonia Theme Part I

Figure 5.23. Var. VIII, mm. 15 -- 23.

The "Marcia funerale" section moves "from the bottom of the keyboard to the top, and from ppp to fff." 89 The "O Maiko Moya" theme is recognized by the three-note motive throughout. Beach presents the initial three-note motive in the right hand while the left hand is constantly playing minor second tremolos. Moreover, the low register with the somber melody,

\footnotetext{
${ }^{89}$ Amy Beach, "Variations on Balkan Themes, Op. 60," in Amy Beach Piano Music, ed. by Sylvia Glickman (New York: Da Capo Press, Inc., 1982), introduction.
} 
and the later chordal build up with the orchestral effects can evoke listeners' memories of the funeral march movement of Chopin's Piano Sonata No 2 in Bb Minor (see Figure 5.24).
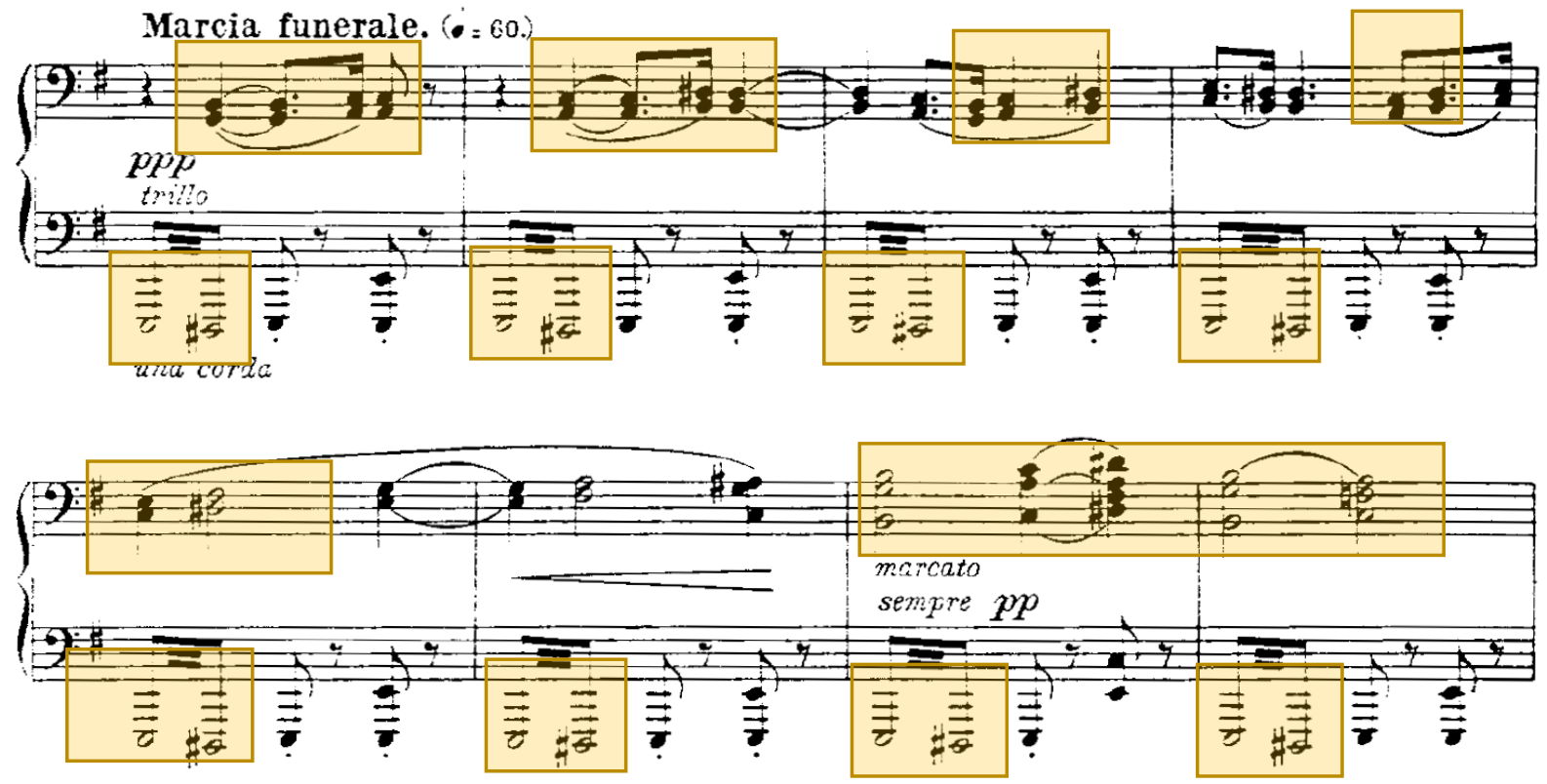

Figure 5.24. Var. VIII, mm. $24-31$.

The "Macedonia" theme part II returns toward the end of the funeral march section. This time Beach uses fuller chords and more orchestral-like textures (see Figure 5.25). 


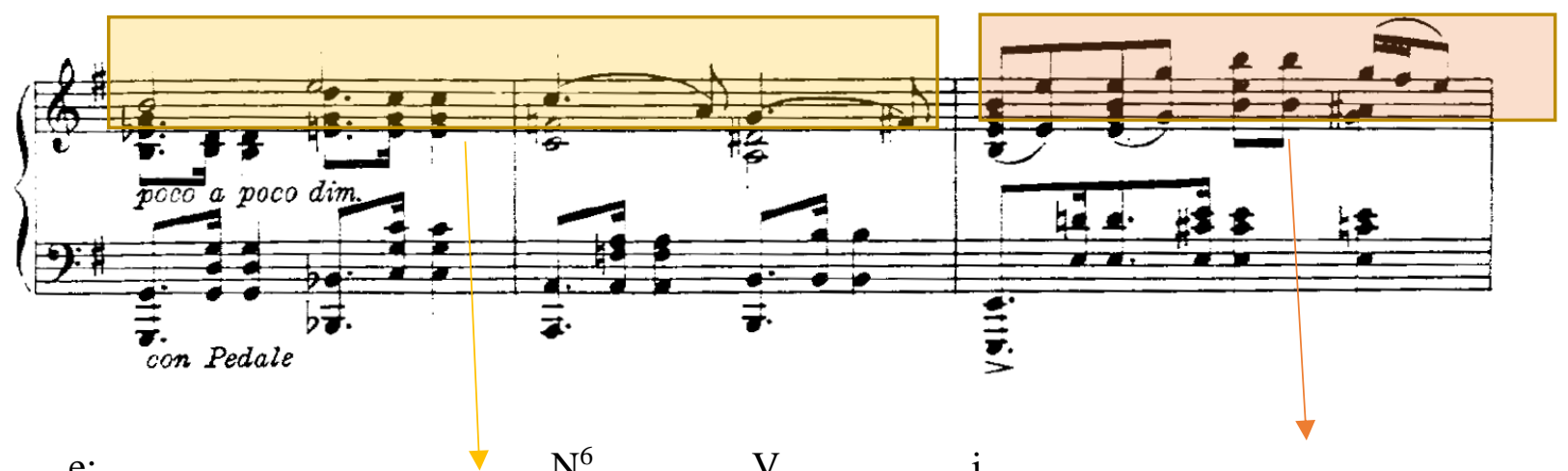

e: "O Maiko Moya" Theme

"Macedonia" Theme Part II

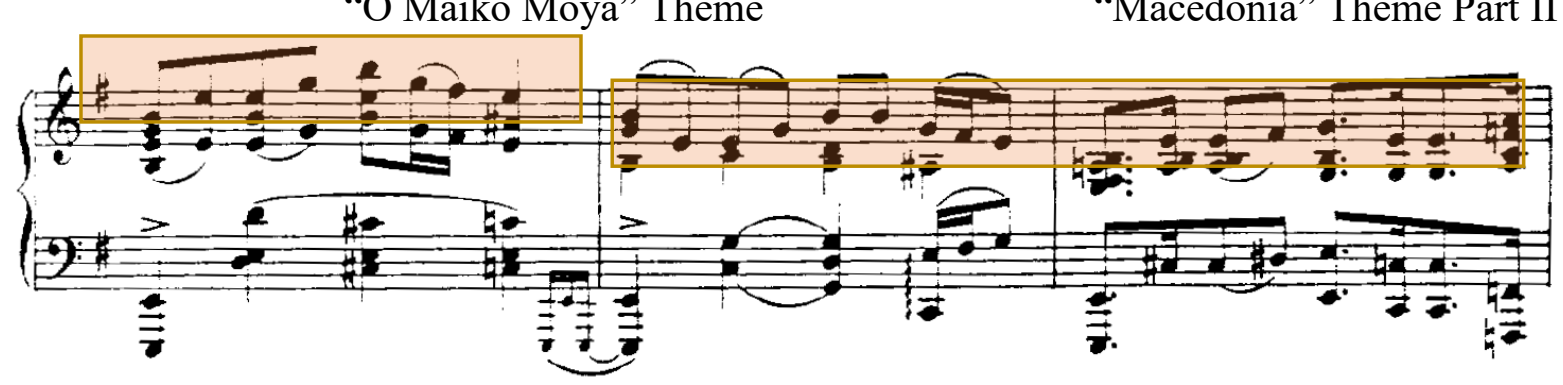

Figure 5.25. Var. VIII, mm. $72-77$.

The "Marcia funerale" opening passage returns in $\mathrm{m}$. 80. This return begins with the tonic "E" on the top while the opening of the "Marcia funerale" has the dominant "B" on the top. The three-note motive appears in different voices at this ending section. Furthermore, this variation ends with a dissonant augmented $\mathrm{V}$ chord in the right hand while the left hand constantly reminds listeners of the tonic "E." This ending is another example of Beach's interesting and creative harmonic language (see Figure 5.26). 

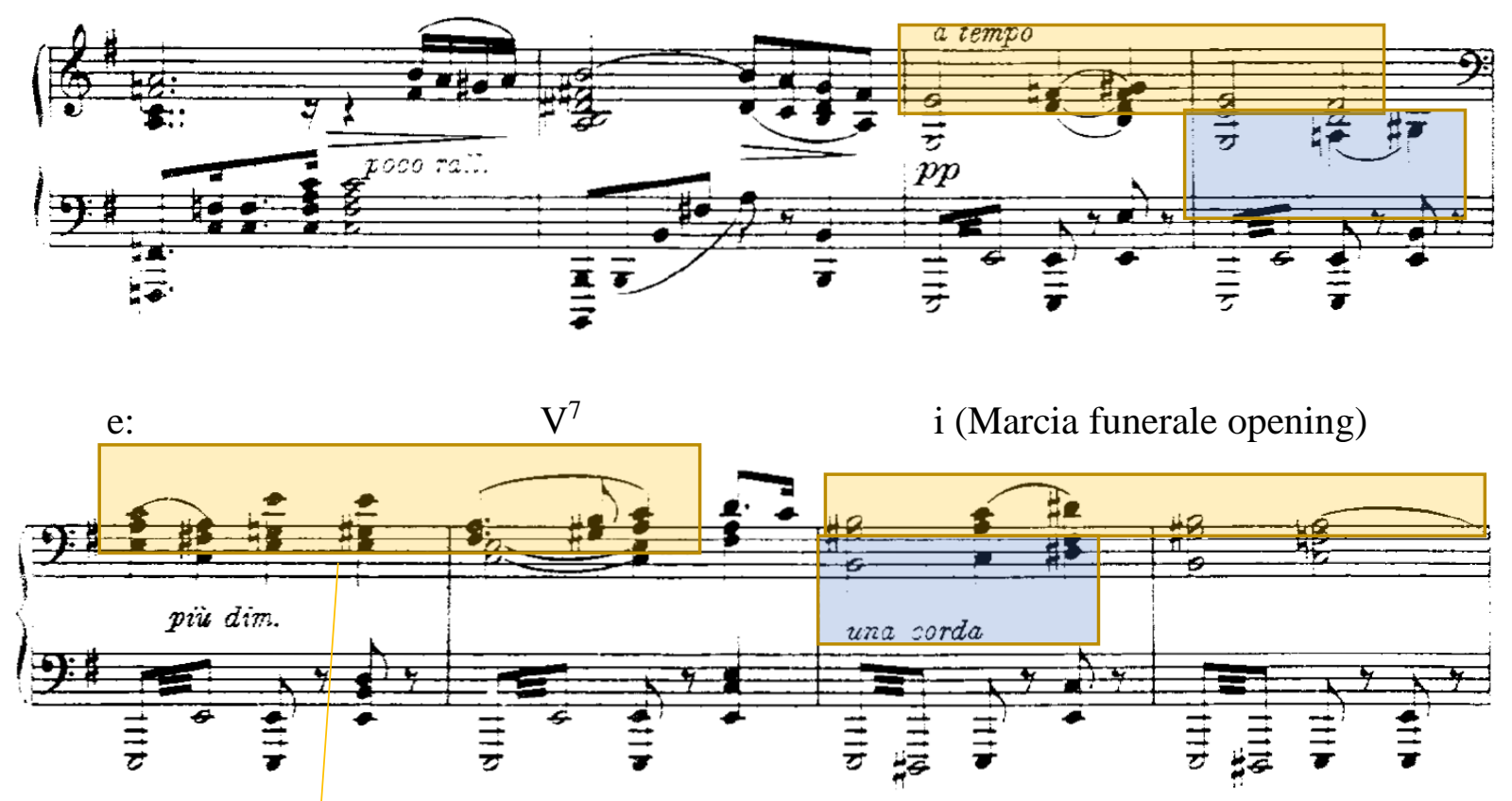

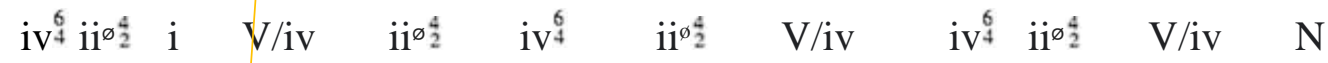

"O Maiko Moya" Theme

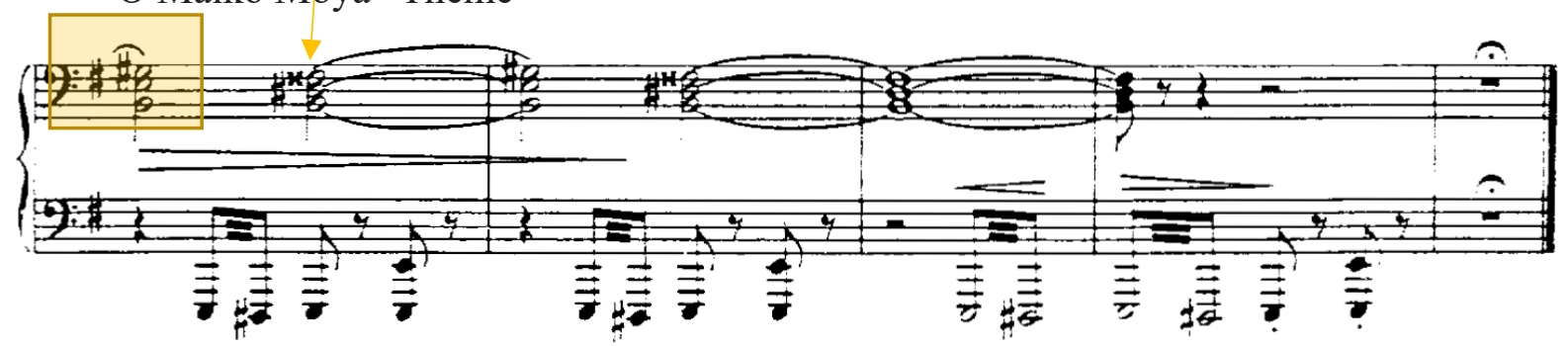

V/iv $\quad$ V+ V/iv $\quad$ V+

Figure 5.26. Var. VIII, mm. $78-90$.

\section{Cadenza}

It is very unusual to put a cadenza in a set of variations. The purpose of a cadenza is to show the technical brilliance of the performer, reestablish the tonic key and strengthen the piece as a whole. Beach's cadenza contains five sections: "Grave," "Quasi fantasia," "Maestoso come Var. II," the "Macedonia" theme, and "Adagio come prima." Beach uses the cadenza to create the longest section of the piece: 100 measures. In the "Grave" section, Beach brings back the "Stara Planina" theme in E minor with a slow and somber character. The last time Beach used 
the "Stara Planina" theme was in the "Quasi Fantasia" section of Variation VI. Though both times the theme are in the similar slow character, they are not in the same key. In Variation VI, Beach uses F\# minor, but here she begins with E minor. Beach then modulates to G\# minor and $\mathrm{Bb}$ major, which sets up the new key for the "Quasi fantasia" section. Moreover, the constant modulation to distant keys make this section more intense (see Figure 5.27).

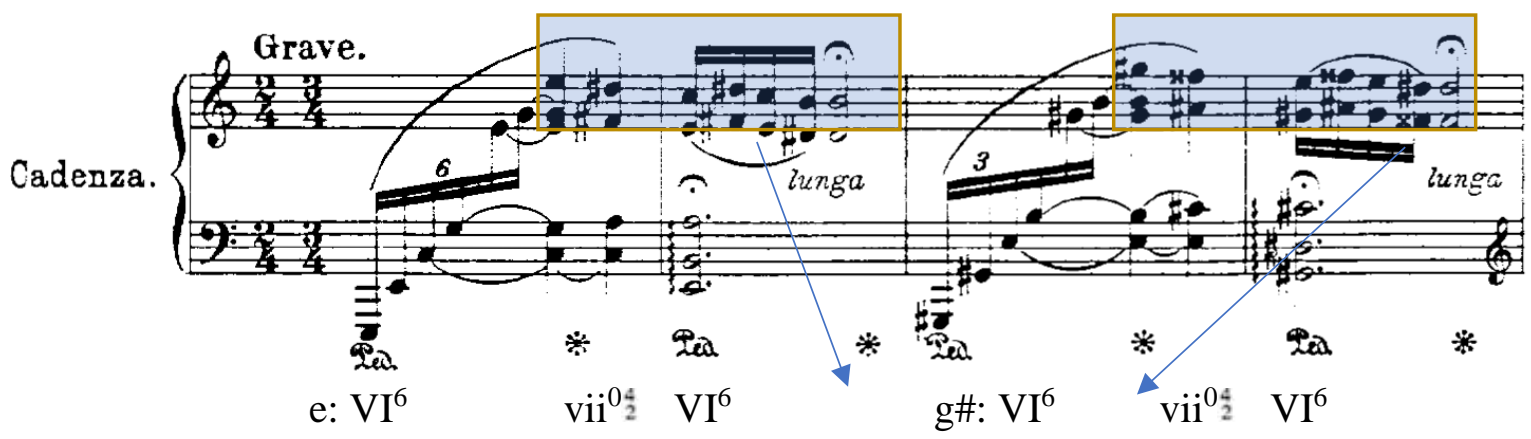

"Stara Planina" Theme

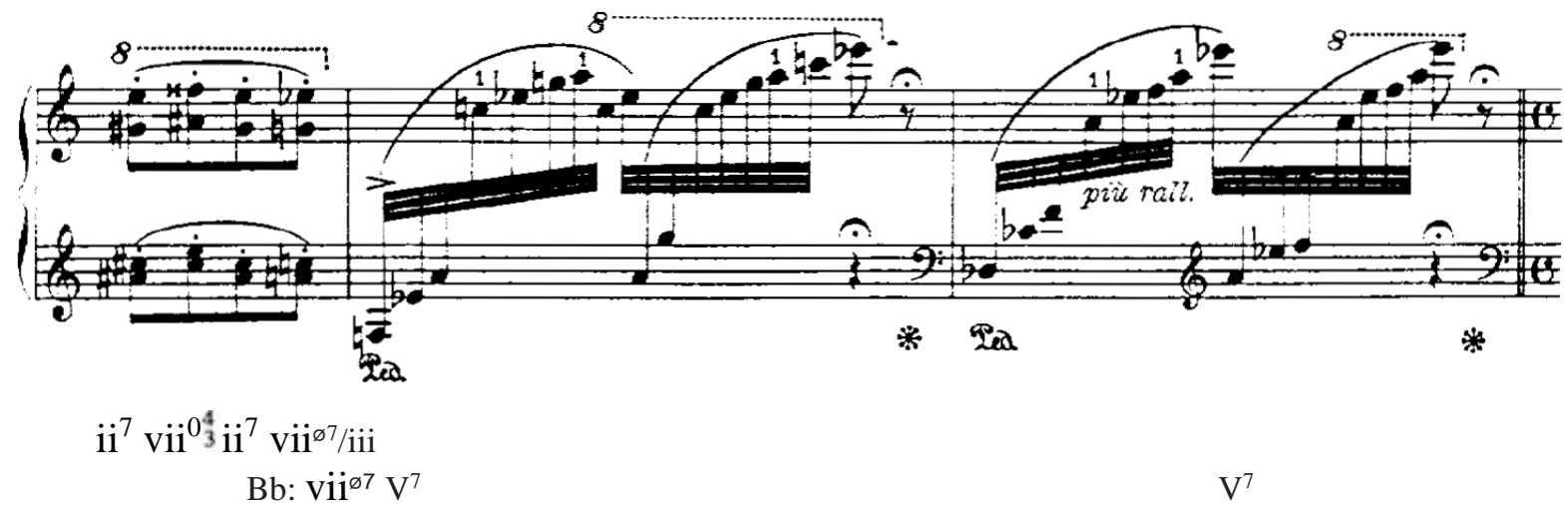

Figure 5.27. Cadenza, mm. 1 -7.

The "Quasi Fantasia" section uses the "O Maiko Moya" motive in both the soprano and tenor voices. This new echoing treatment of the "O Maiko Moya" theme is accompanied by harp-like rapid figures (see Figure 5.28). 


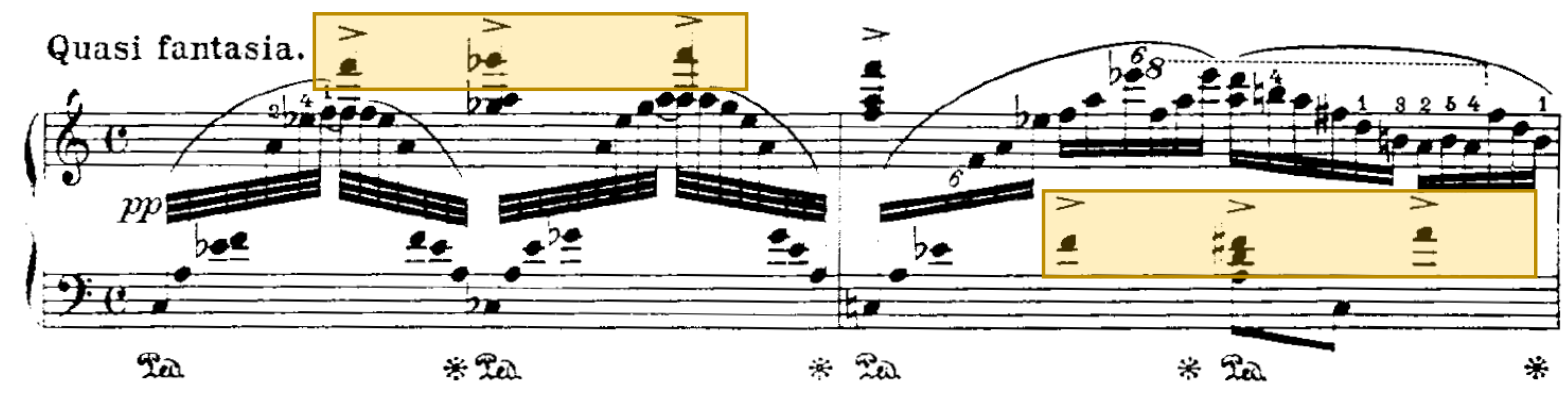

Figure 5.28. Cadenza, mm. 8 -9.

Beach also uses a whole-tone scale in thirds in this section (see Figure 5.29).

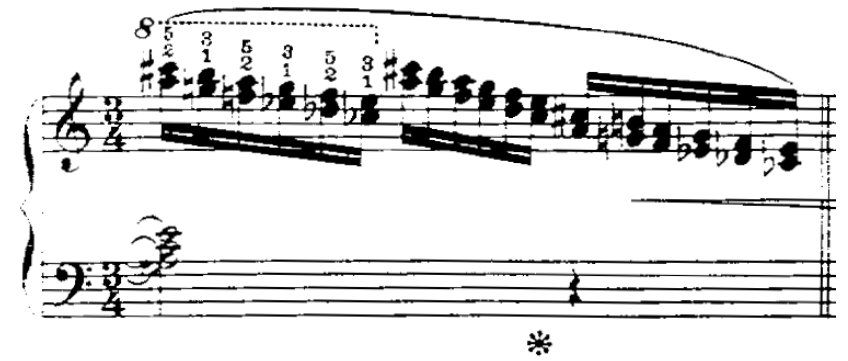

Figure 5.29. Cadenza, mm. 16.

Toward the end of the "Quasi fantasia" section, Beach has combined the motive of the "O Maiko Moya" theme together with the "Stara Planina" theme. She uses tremolos in the left hand to bring out the initial three-note motive of the "O Maiko Moya" theme and combines it with fragments of "Stara Planina" theme in the right hand. This combination of themes further increases the intensity of the music. At the same time, the tonic key (C\# minor) is also established through the motive (see Figure 5.30). 


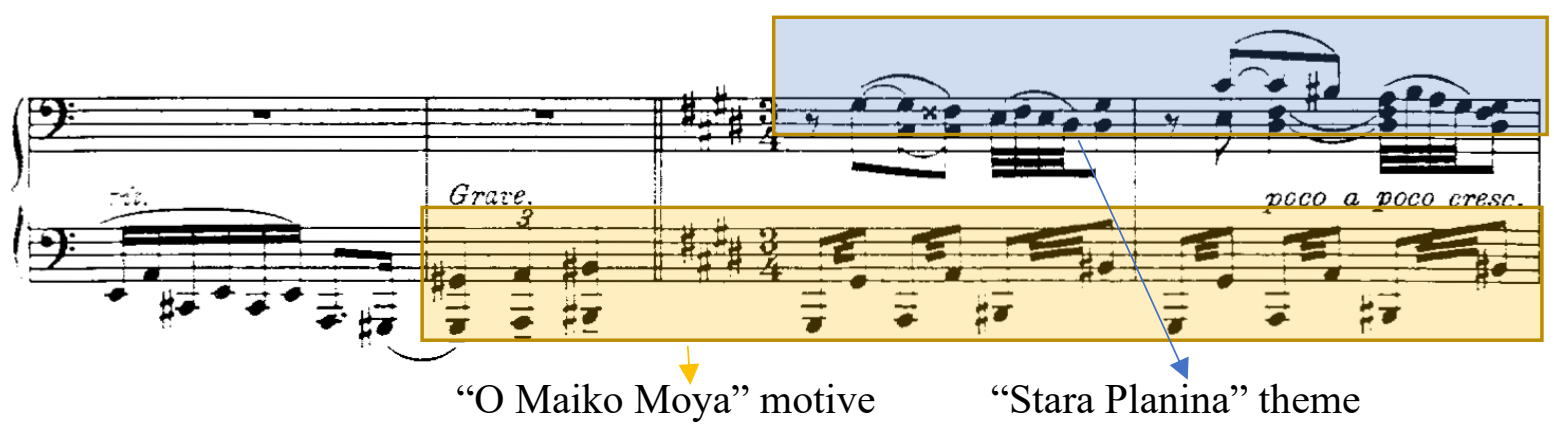

Figure 5.30. Cadenza, mm. $19-22$.

In $\mathrm{m} .28$, Beach brings back material from Variation II in the tonic C\# minor. This return of the Variation II section is very orchestral like and filled with chords, octaves, and fast arpeggios. It fully shows the virtuosic side of this piece (see Figure 5.31).

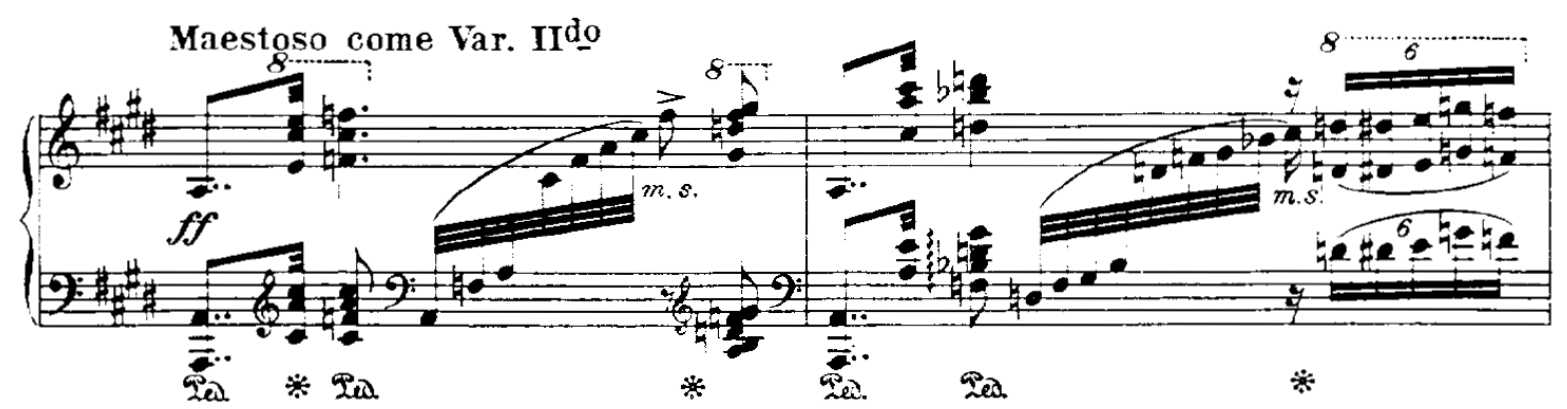

c\#: VI $\quad$ bIV $^{+} \quad \operatorname{vii}^{\rho_{2}^{4}}$ VI $\quad \mathrm{N}^{4} / \mathrm{vi}$

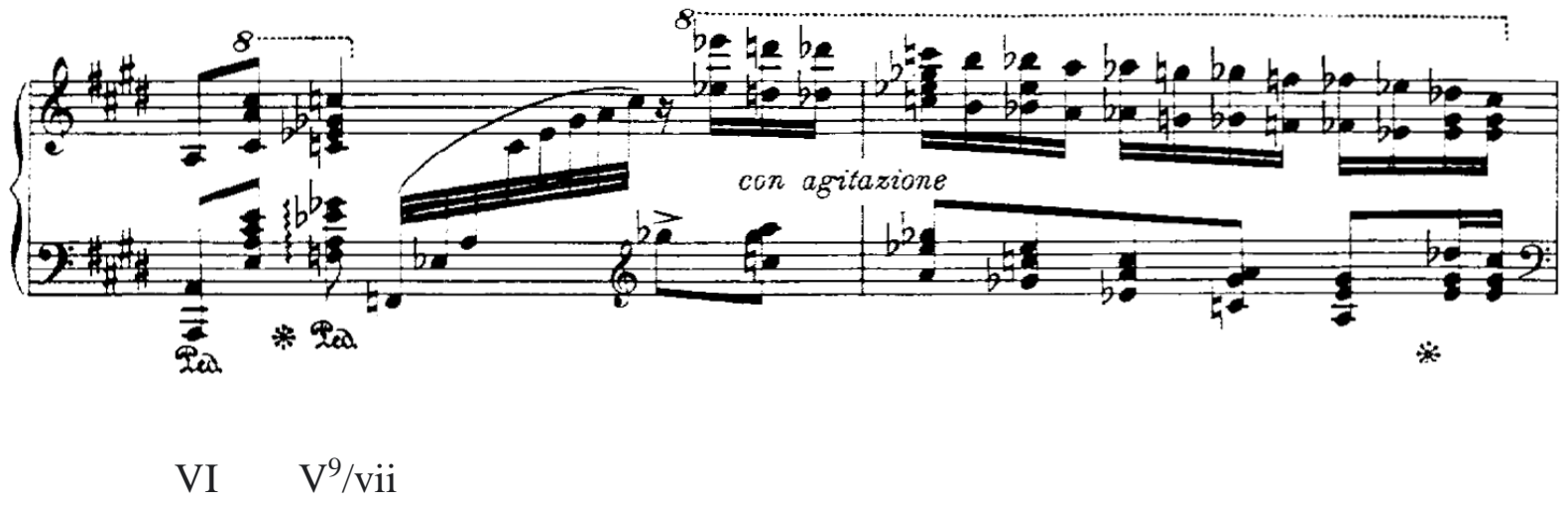

Figure 5.31. Cadenza, mm. $28-31$. 
In $\mathrm{m} .47$, Beach uses the second theme "Stara Planina" again, but this time it is very passionate and strong. Beach uses "marcatissimo" for it, and the texture is rich and full. Beach uses octaves and chords to enhance the orchestral effect (see Figure 5.32).

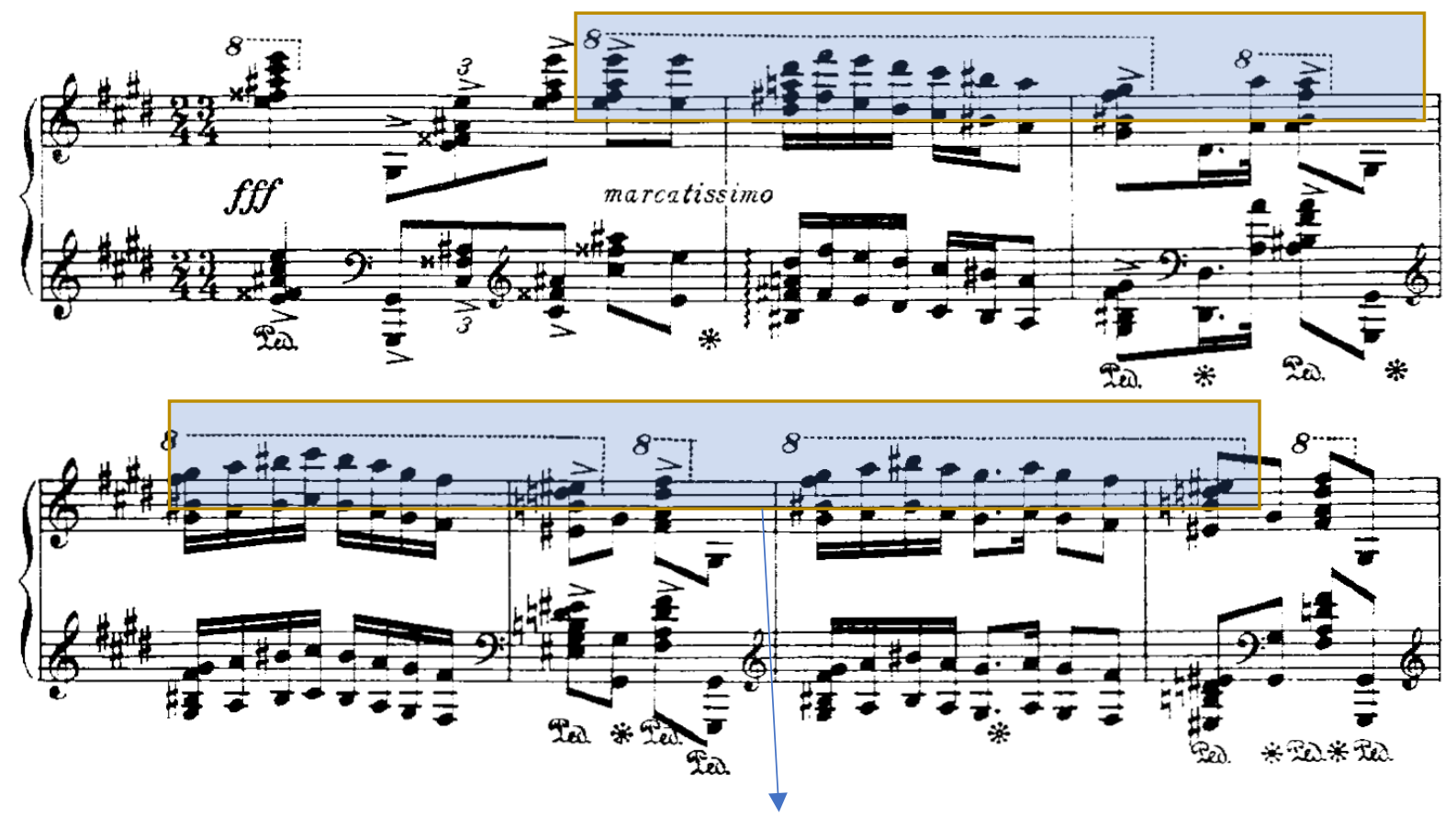

"Stara Planina" theme

Figure 5.32. Cadenza, mm. $47-53$.

This furious and fiery section ends with a dominant pedal in the left hand and chromatic octaves in the right hand. At the same time, it prepares for the "Macedonia" theme to return. Compared to the last time this theme appeared which was in the "Lento calmato" section of Variation VIII, Beach now uses the "Macedonia" theme part II as a strong outcry of the Balkan people's hope for help. Beach uses a much stronger dynamic and a dominant pedal here to enhance the intensity of feeling and prepares for the final return of the opening theme (see Figure 5.33). 

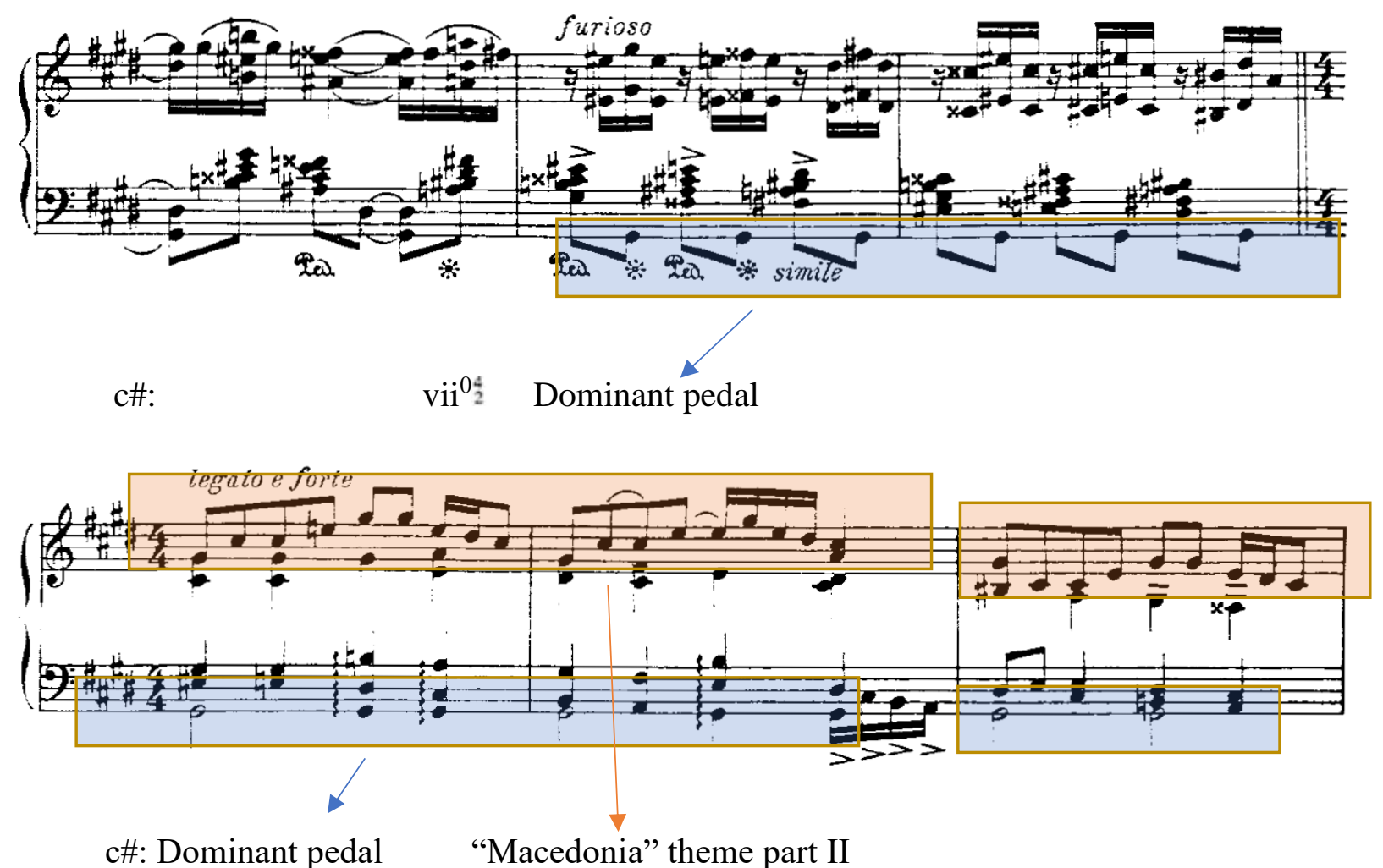

Figure 5.33. Cadenza, mm. $58-63$.

Furthermore, Beach ends this cadenza with both a ritardando and a slowing down of the note values. This helps to naturally calm the furious, passionate, and fiery atmosphere, and sets a calm and expressive stage for the final return of the opening theme (see Figure 5.34).

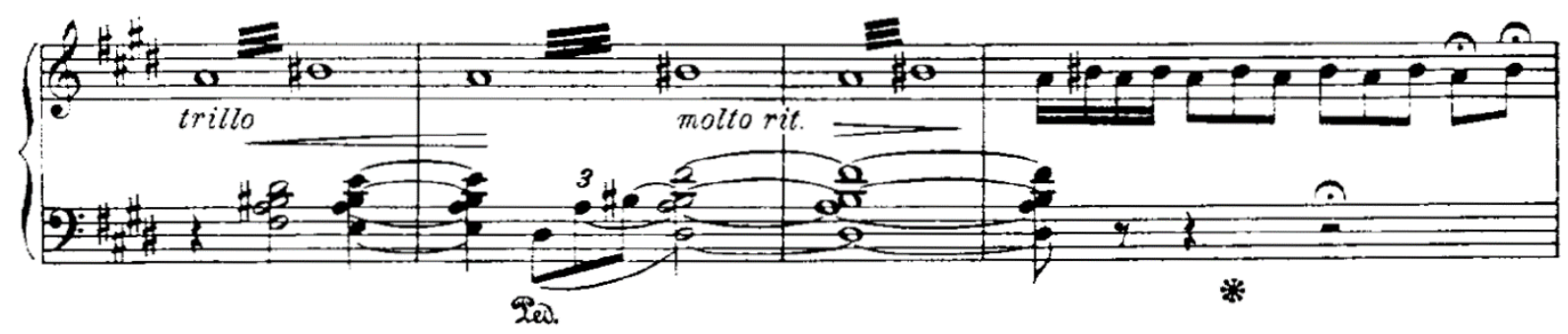

Figure 5.34. Cadenza, mm.70 - 73. 
The "Adagio come prima" section is the final return of the opening theme "O Maiko Moya" in C\# minor. It is almost in its original form, but with a "reference to the counterpoint of the first variation" 90 (see Figure 5.35).
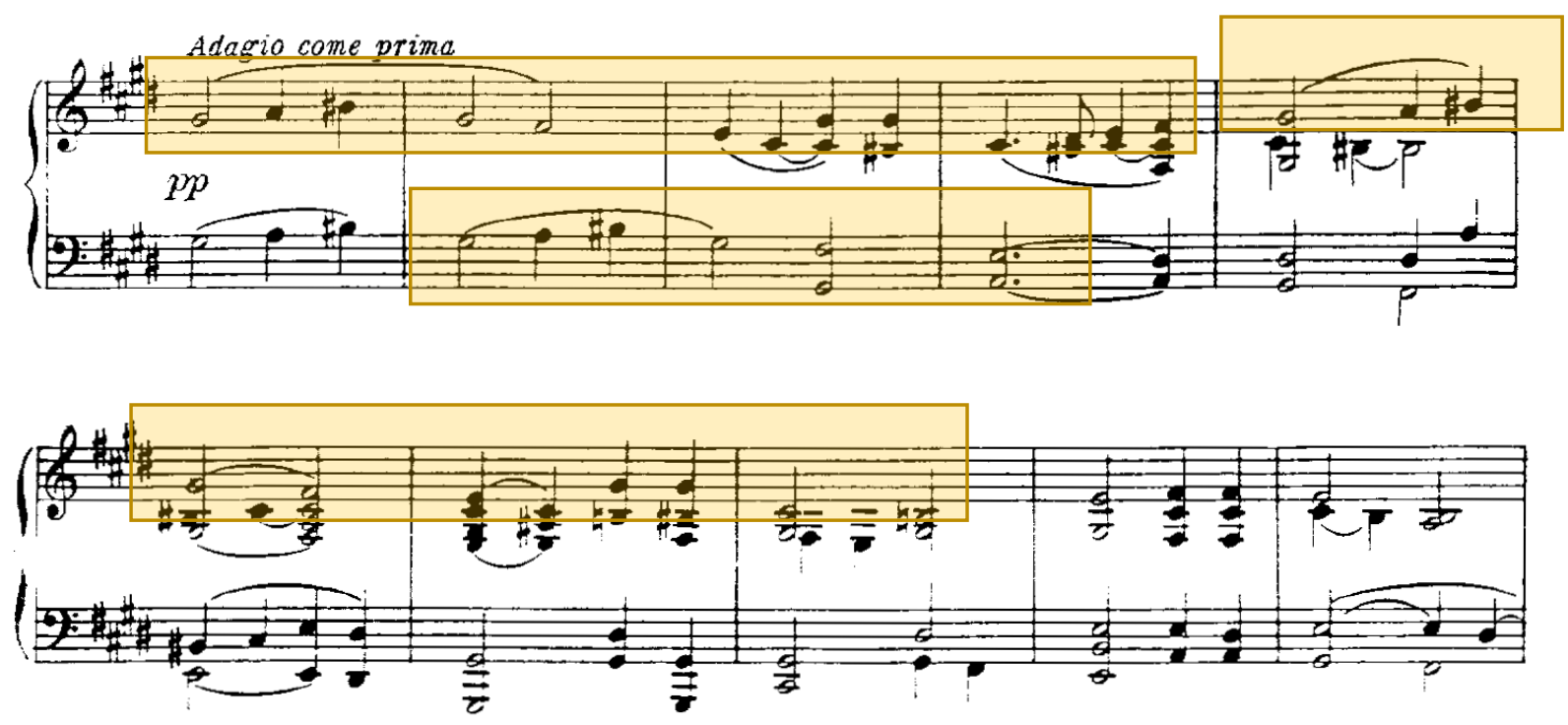

Figure 5.35. Cadenza, mm. $74-83$.

This section follows the structure of the opening theme, but with the addition of the "Macedonia" theme. Beach combines the "Macedonia" theme together with the "O Maiko Moya" motive to strengthen the thematic connection. At the same time, it makes this "Adagio come prima" section longer than the opening theme with the addition of seven measures. Harmonically, it follows the same tonal scheme pattern of the opening theme (c\# -- E - c\#) except Beach ends the piece with a C\# major chord. This chord could symbolize the Balkan people's hope for freedom (see Figure 5.36).

\footnotetext{
${ }^{90}$ E. Douglas Bomberger, "Motivic Development in Amy Beach's Variations on Balkan Themes, Op. 60," American
} Music 10, No. 3 (1992): 341. 

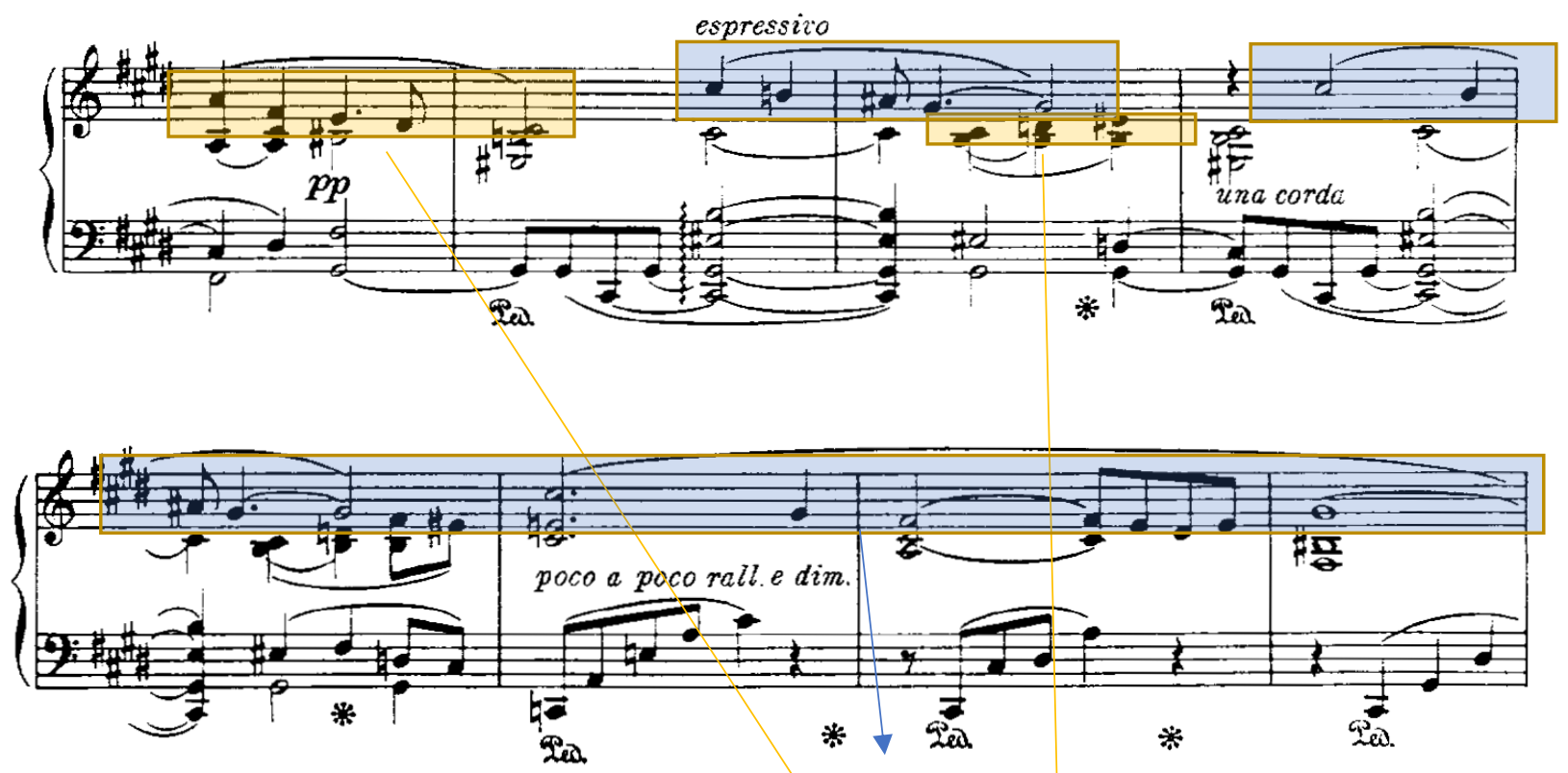

"Macedonia" Theme Part I

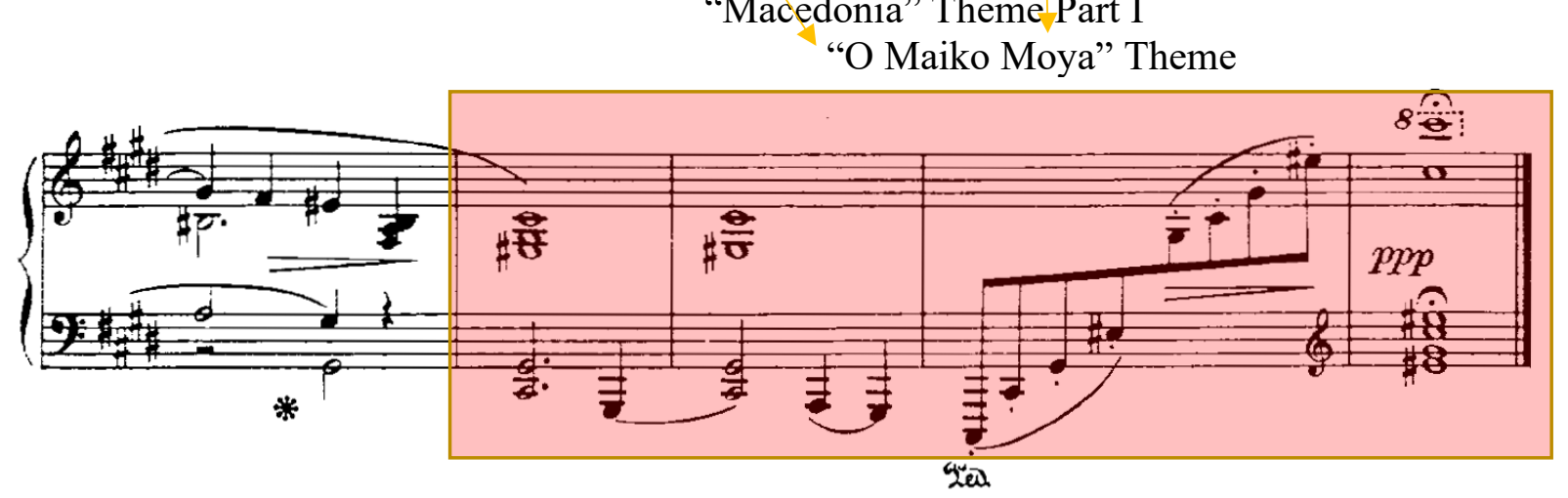

C\# major chord

Figure 5.36. Cadenza, mm. 88 - 100.

This cadenza makes references to earlier variations and three of the Balkan themes, thus it strengthens "the work's status as a set of variations on several Balkan themes rather than a set of variations on "O Maiko Moya" with an occasional bit of local color added." ${ }^{\text {" }}$ Reestablishing the tonic key (C\# minor) and bringing the motive to the forefront of the listeners' ears, also

\footnotetext{
${ }^{91}$ E. Douglas Bomberger, "Motivic Development in Amy Beach's Variations on Balkan Themes, Op. 60," American
} Music 10, No. 3 (1992): 342. 
makes this cadenza a significant part of this important piece. Additionally, the virtuosity here also shows how technically demanding this piece is. Hence, the cadenza section makes the piece more united and satisfying.

\section{Third Relationship in the Tonal Scheme}

The overall tonal scheme of Variations on Balkan Themes is based on third relationships, and according to E. Douglas Bomberger and Adrienne Fried Block's, “On Beach's Variations on Balkan Themes, Op. 60," its tonal scheme is very similar to Beethoven's Six Variations, Op. 34. Amy Beach knew Beethoven's Op. 34 very well since it was performed by her regularly. Hence, based on the similarities between these two pieces, it is very likely that Beach uses Beethoven's Op. 34 as a model. Beach borrowed the tonal scheme of Beethoven's Op. 34 in "modified form for her variation set." 92 In Beethoven's Op. 34, each variation is “in a tonality a third lower than the previous, until the minor dominant is reached. Internally each variation moves from tonic to dominant and back to tonic." ${ }^{93}$ Similar to Beethoven's tonal scheme, the third relationship also plays a significant role in Beach's set of variations. In each variation, the tonality is modulating by a third relationship. Therefore, the third relationship is significant in the overall tonal scheme of both pieces.

\section{Rhythm, Dynamics, Tempo}

Like many of Beach's works, the rhythmic meters in this piece are not complex. She chose simple and compound meters except in Variation VI and the Cadenza. In these two sections, she uses 2/4+3/4. Like many conservative composers, she usually keeps the same meter within the same section or the same variation.

\footnotetext{
92 E. Douglas Bomberger and Adrienne Fried Block, "On Beach's Variations on Balkan Themes, Op. 60," American Music 11, No. 3 (1993): 369.

93 Ibid., 370.
} 
The dynamic range is from ppp to fff. Crescendo, diminuendo, sforzando, and accent are frequently used. All these dynamics are part of Beach's musical expression and show her sensitivity to a broad range of sound. In addition to dynamics, Beach also applies many tempo indications with descriptions, such as “Adagio malincolico," "Andante alla Barcarola," and “Allegro all'Ongarese." Ritardando and accelerando are often used, especially in transitional sections. "Although metronome markings are sometimes present, Mrs. Beach most often leaves the exact decision about tempo to the discretion of the performer." 94 Therefore, her rhythm, dynamics and tempo in Variations on Balkan Themes suggests it is a piece of the Romantic style.

\section{Beach's Manuscripts}

Three pages of Beach's manuscript of Variations on Balkan themes are presented below (see Figures 5.37, 5.38 and 5.39).

\footnotetext{
${ }^{94}$ Marmaduke Sidney Miles, "The Solo Piano Works of Mrs. H.H.A. Beach,” DMA diss., (Peabody Conservatory
} of Music, 1985), 150. 


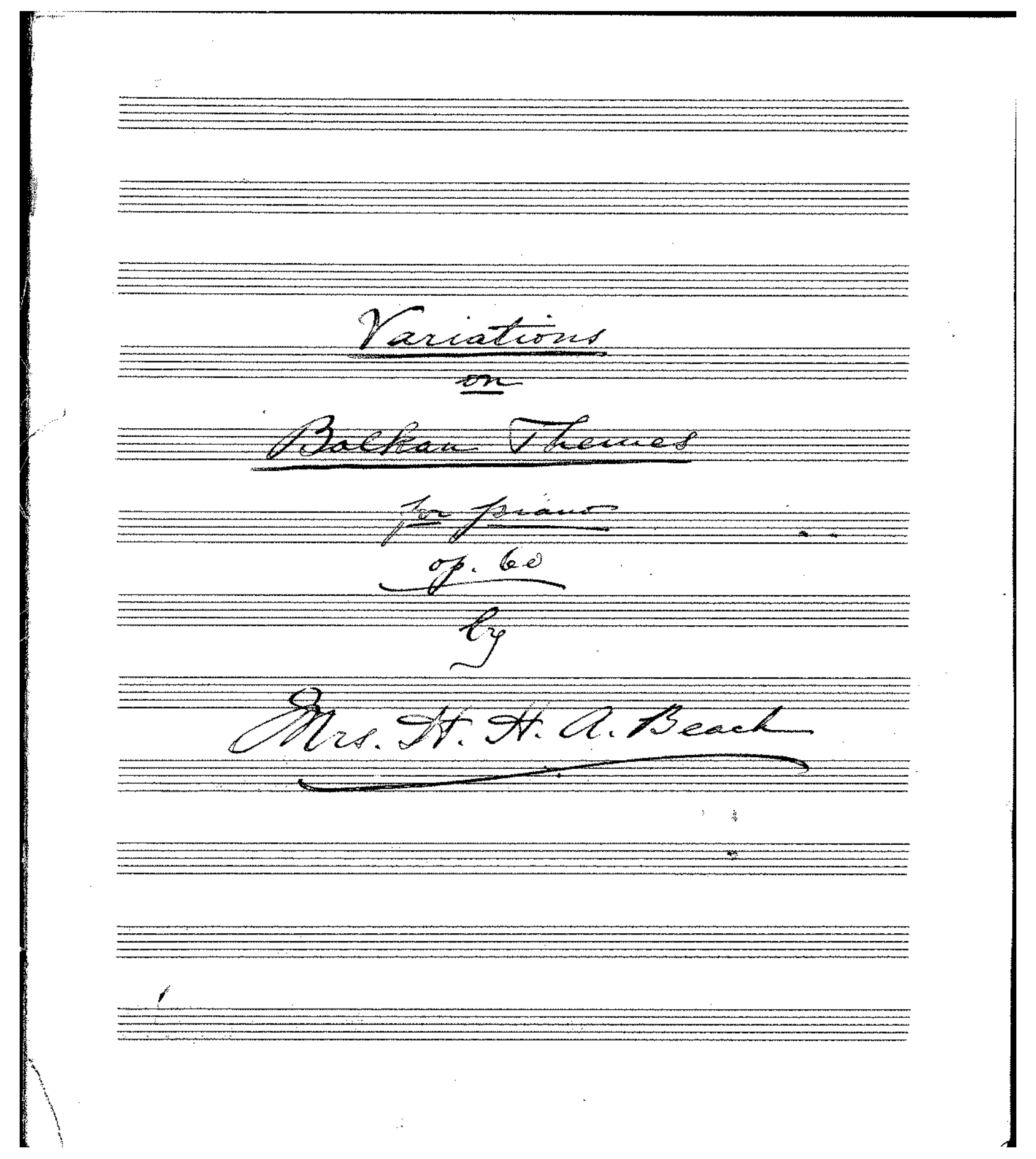

Figure 5.37. Cover Page of Manuscript 


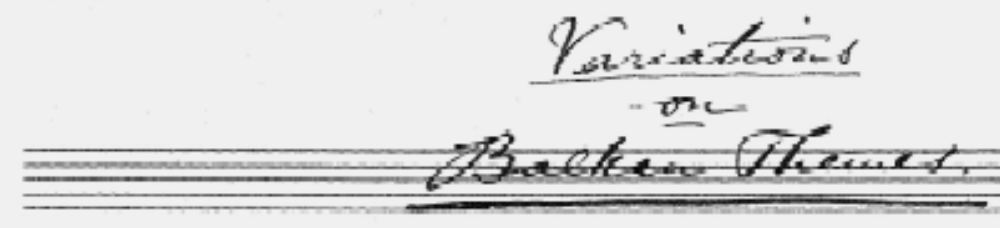

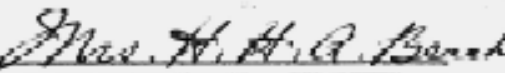

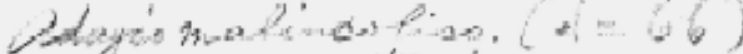

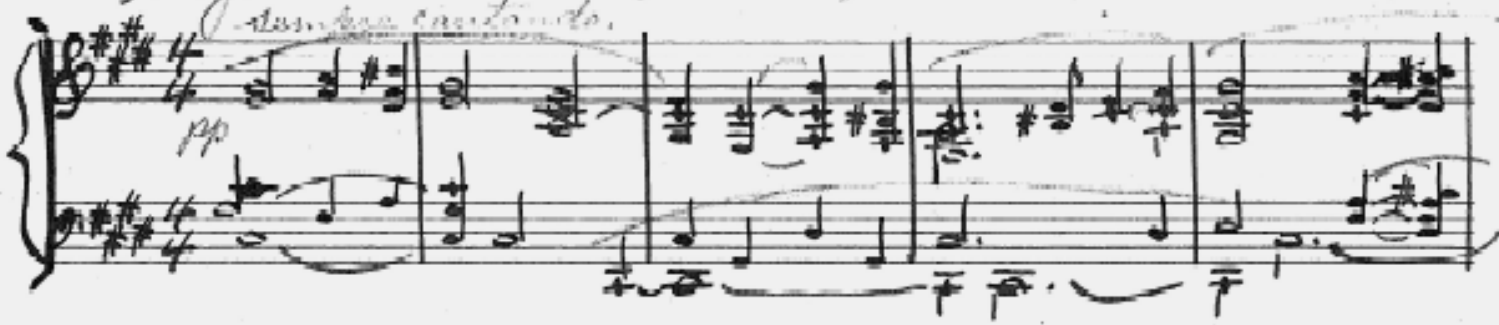
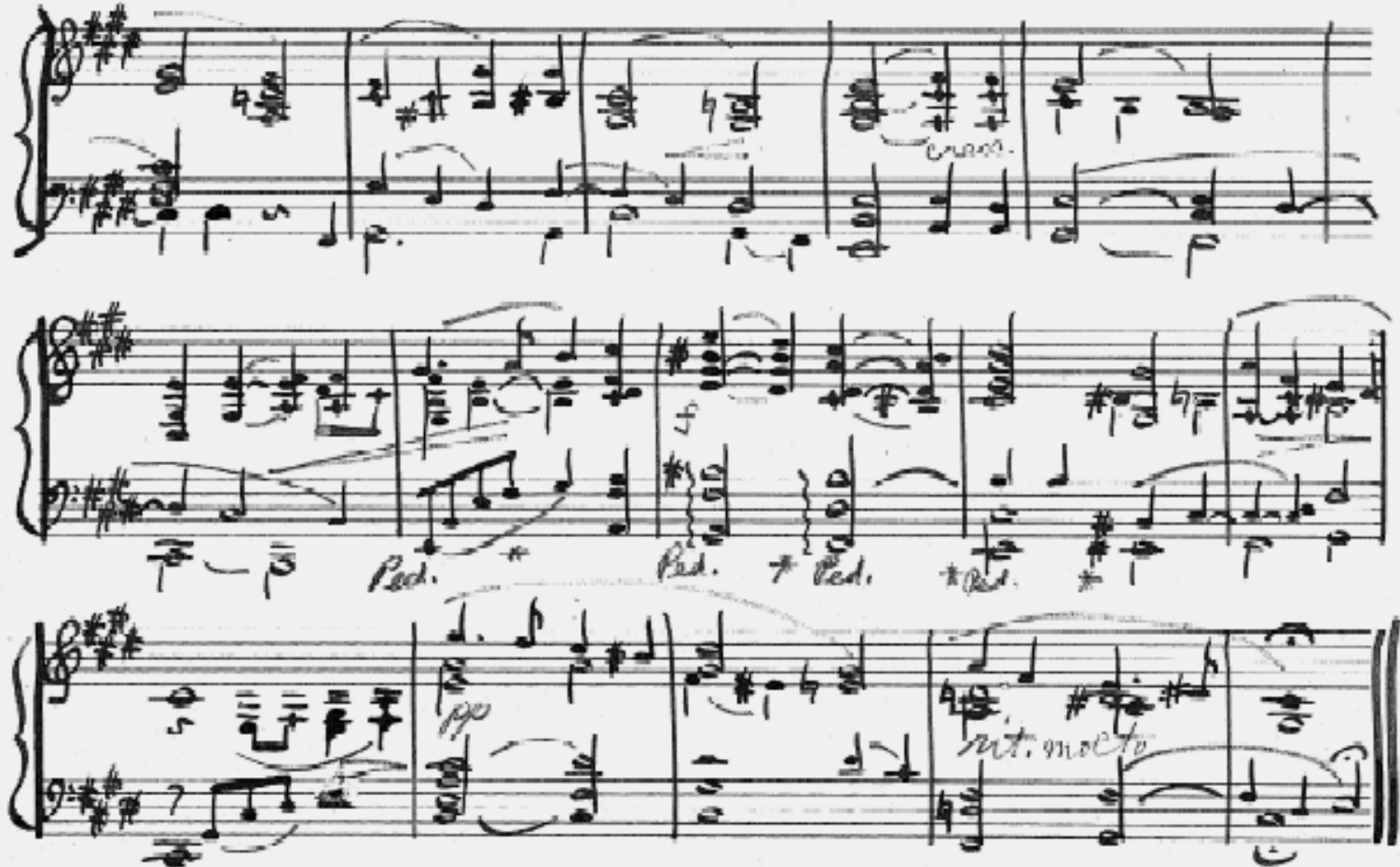

in onovo. $(1-92)$

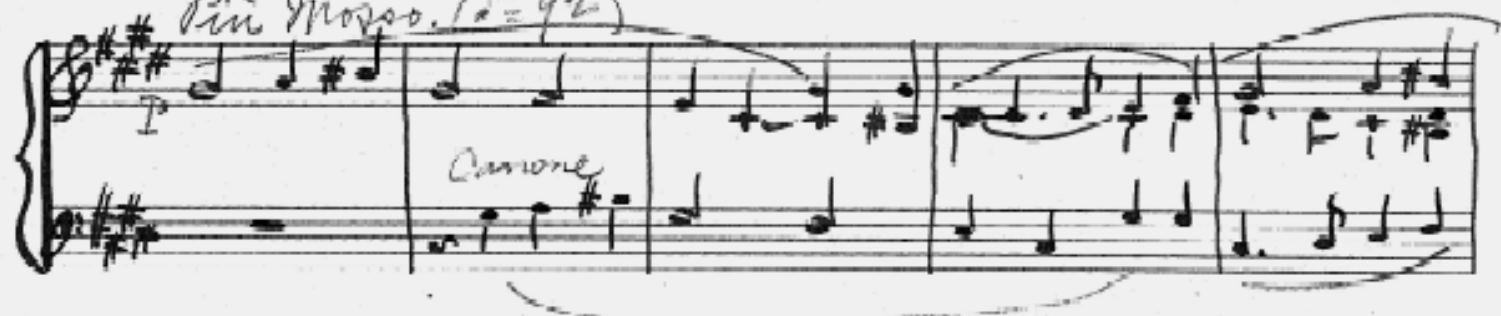

Figure 5.38. Theme from Manuscript 

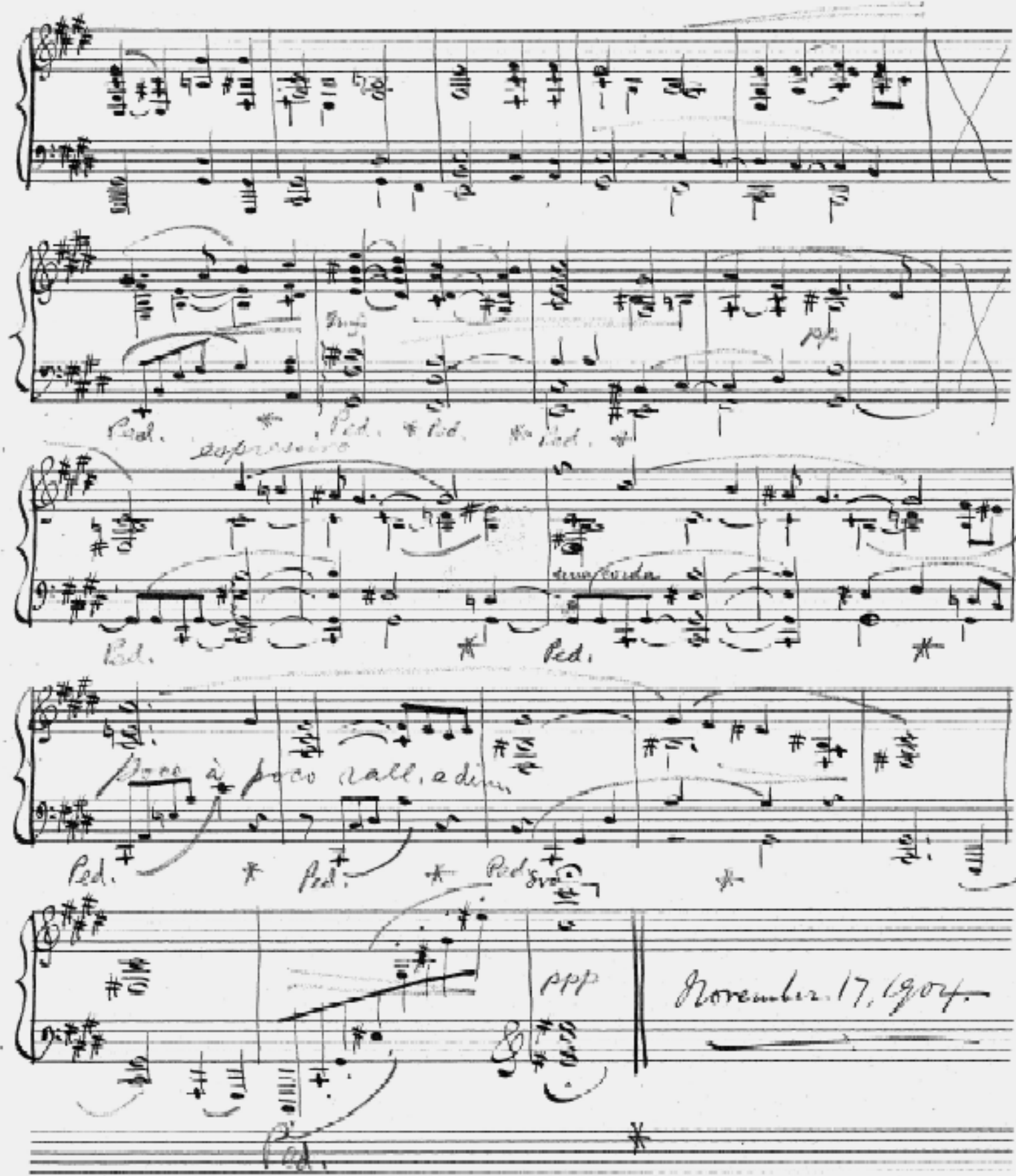

Figure 5.39. Final Page of Manuscript with Completion Date 


\section{CHAPTER VI}

\section{Transcriptions of Variations on Balkan Themes}

Amy Beach created four versions of Variations on Balkan Themes. The original 1906 solo piano version of the piece is analyzed in detail in Chapter 5. The other three versions are: a 1936 revised solo piano version, a 1942 two-piano version and an orchestral arrangement. The reason Beach decided to make revisions was to increase sales, also she agreed with critics who thought the original version was too long. ${ }^{95}$ She wanted the revisions to be simpler and shorter to suit the "current" day music. She stated, "people nowadays did not need to hear so much repetition." ${ }^{96}$ Variations on Balkan Themes was not the only piece she made major cuts in the revision, she had also made cuts in her Piano Concerto, Op. 45 and her Sonata for Violin and Piano, Op. 34.

Furthermore, besides eliminating repeats in the 1936 revised solo piano and 1942 twopiano versions of Variations on Balkan Themes, Beach also "transposed the last section, consisting of the extended Marcia funerale and a shortened coda, into Eb minor. These changes emphasize the tragic messages of the associated folk-song texts. ${ }^{.97}$ Also, ending in Eb minor with an Eb major chord instead of the original key of $\mathrm{C \#}$ minor shows Beach's progressive tonality of the late Romantic style.

Moreover, "in 1906, Arthur P. Schmidt published the first edition of Variations on Balkan Themes. This edition advertised the availability of an arrangement in manuscript for

\footnotetext{
${ }^{95}$ E. Douglas Bomberger and Adrienne Fried Block, "On Beach's Variations on Balkan Themes, Op. 60," American Music 11, No. 3 (1993): 368.

${ }^{96} \mathrm{Ibid}$.

${ }^{97}$ Adrienne Fried Block, Amy Beach, Passionate Victorian: The Life and Work of an American Composer, 18671944. (New York: Oxford University Press, 1998), 268.
} 
orchestra, though only a fragment has been unearthed to date."98 Therefore, the orchestral arrangement is fragmented while the other three versions are completed. In this chapter, the focus will be the differences among the versions.

\section{Revised Solo Piano Version}

The 1936 revised solo piano version is much shorter than the original version. Beach eliminated the repeats and the entire cadenza. The revised edition ended with Eb major chord instead of C\# major chord. A detailed comparison between the two editions is shown below (see

Figure 6.1).

\begin{tabular}{|l|l|}
\hline Original & Revised \\
\hline Theme & Theme (identical) \\
\hline Variation I & Variation I (identical) \\
\hline Variation II & Variation II (identical) \\
\hline Variation III & Variation III (no repeat) \\
\hline Variation IV & Variation IV (no repeat) \\
\hline Variation V & Variation V (identical) \\
\hline Variation VI - Quasi Fantasia & Variation VI - Quasi Fantasia (identical) \\
\hline Variation VI - Allegro all'Ongarese & Variation VII \\
\hline Variation VI - a tempo & Variation VIII \\
\hline Variation VII & $\begin{array}{l}\text { Variation IX (no repeat, last 7 measures } \\
\text { contained revised material) }\end{array}$ \\
\hline Variation VIII - Con vigore - Lento calmato & $\begin{array}{l}\text { Variation X - Con vigore - Allegretto (It is } \\
\text { shortened, and the Macedonia theme is in Eb } \\
\text { minor instead of E minor. The tempo marking } \\
\text { of the Macedonia theme is also different. })\end{array}$ \\
\hline $\begin{array}{l}\text { Variation VIII - Marcia funerale (4/4-meter, } \\
\text { E minor - G Major - E minor) }\end{array}$ & $\begin{array}{l}\text { Variation XI - Marcia funerale (2/4-meter, } \\
\text { Eb minor - Gb Major - Eb minor) }\end{array}$ \\
\hline Cadenza & \begin{tabular}{l} 
Deleted \\
\hline Adagio come prima (C\# minor)
\end{tabular} \\
$\begin{array}{l}\text { Molto lento (based on the last two lines of the } \\
\text { original, and it is in Eb minor) }\end{array}$ \\
\hline
\end{tabular}

Figure 6.1. Comparison Between Original and Revised Versions

\footnotetext{
${ }^{98}$ Hector Valdivia, “Amy Beach (1867-1944)," in Women Composers: Music Through the Ages, Volume 8. Sylvia Glickman and Martha Furman Schleifer, (MI: Thomson Corporation, 1996), 369.
} 
The Theme, Variation I and Variation II are the same in both the original and revised solo piano versions. There are no repeats in the revised solo piano version of Variation III and Variation IV. Variation V and the Quasi Fantasia section of Variation VI are the same in both versions. However, the Allegro all'Ongarese and the a tempo section of Variation VI of the original version becomes Variation VII and VIII in the revised solo piano version. Variation VII of the original becomes Variation IX of the revised solo piano version, and there is no repeat in the revised solo piano version. The last seven measures of Variation IX are revised and shortened, and they are not same as the second ending and coda of the original version (see Figures 6.2 and 6.3). 

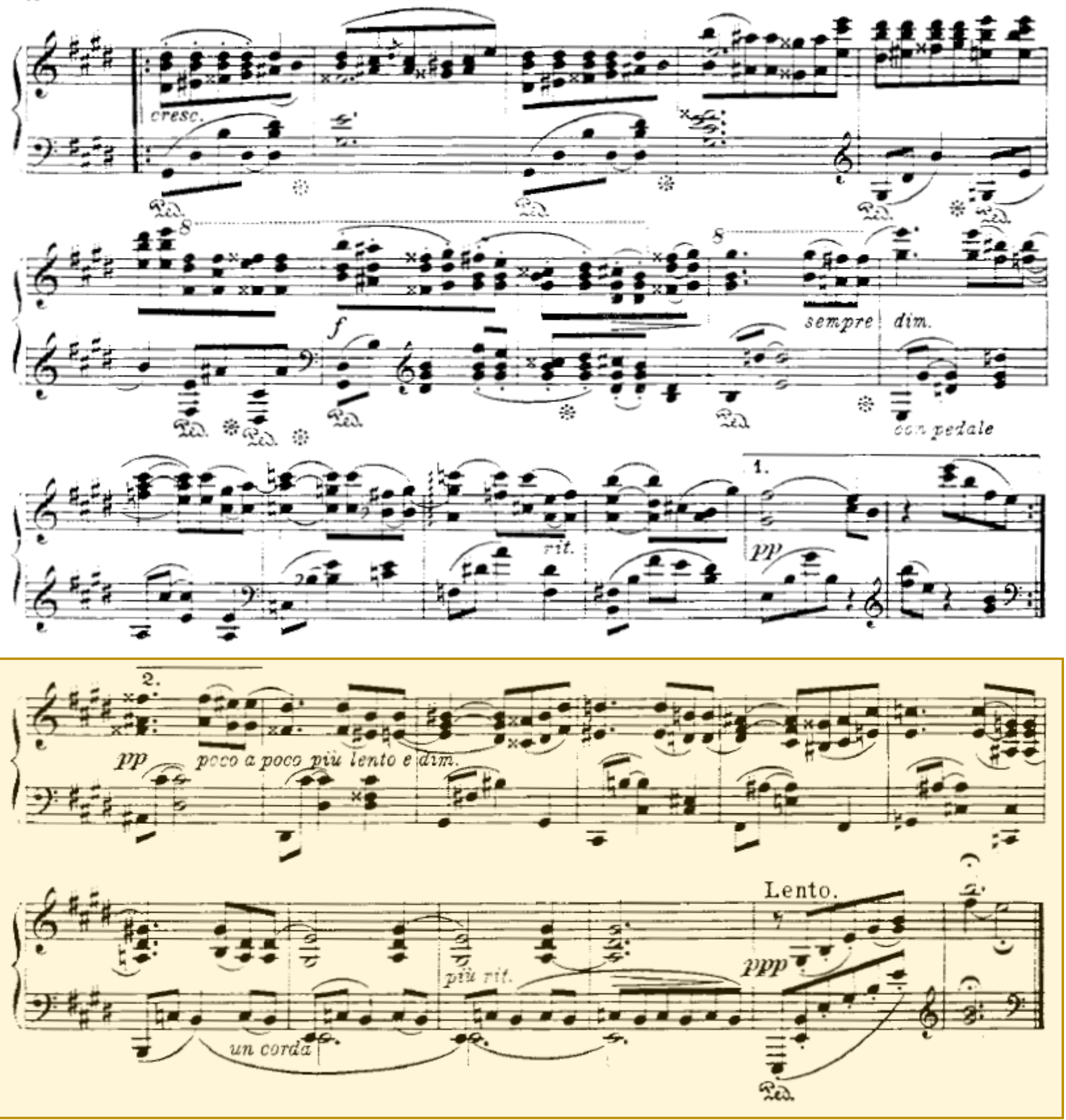

Figure 6.2. Original Version, Var. VII, mm. 20 - 47. 

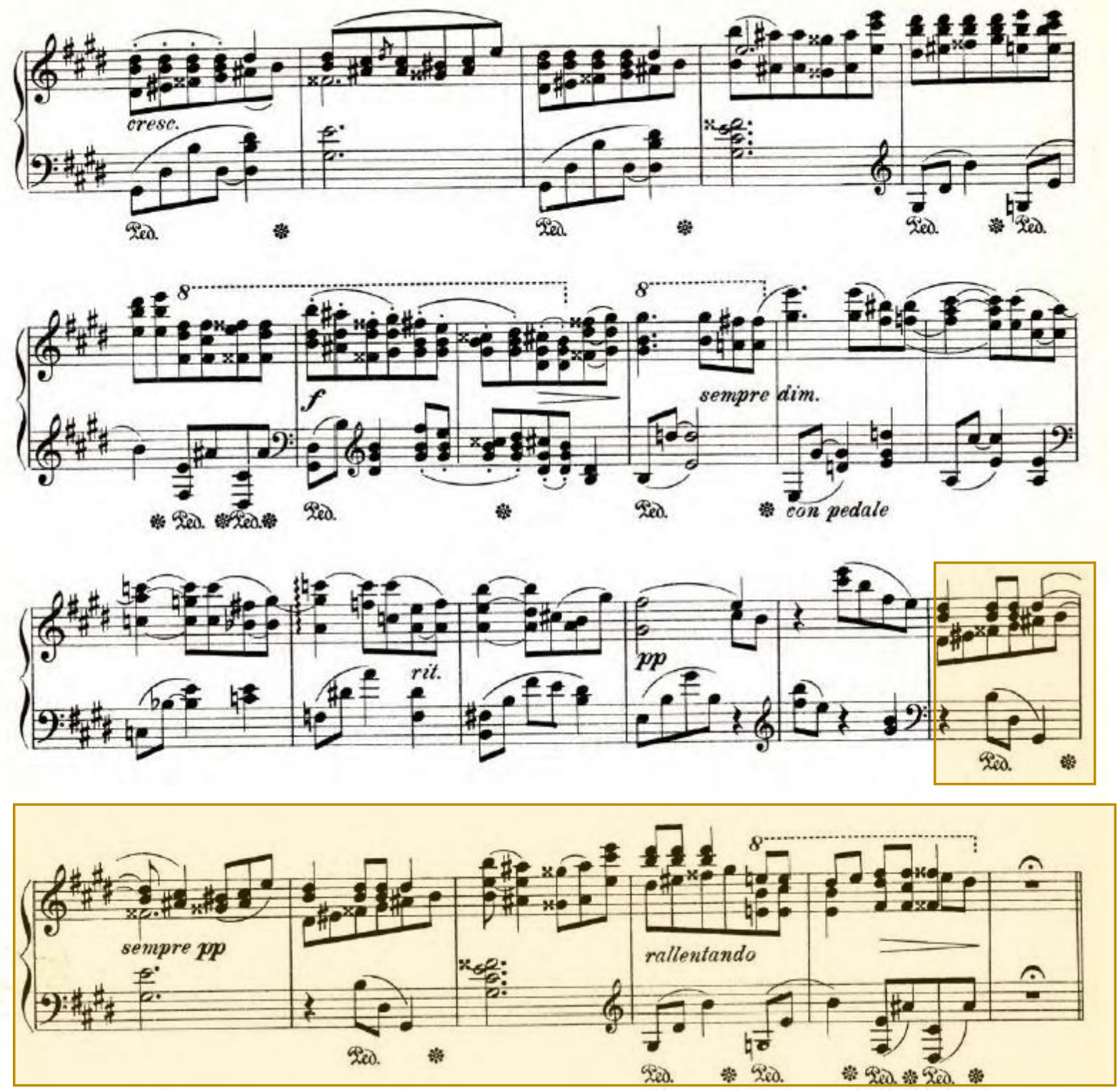

Figure 6.3. Revised Solo Piano Version, Var. IX, mm. 20 - 42.

In both Variation VIII of the original and Variation X of the revised solo piano versions, the Con vigore sections are in $\mathrm{G} \#$ minor. However, Variation $\mathrm{X}$ in the revised solo piano version is much shorter than Variation VIII of the original. There are only 6 measures in Var. X of the revised solo piano version, but 14 measures in the original (see Figures 6.4 and 6.5). 

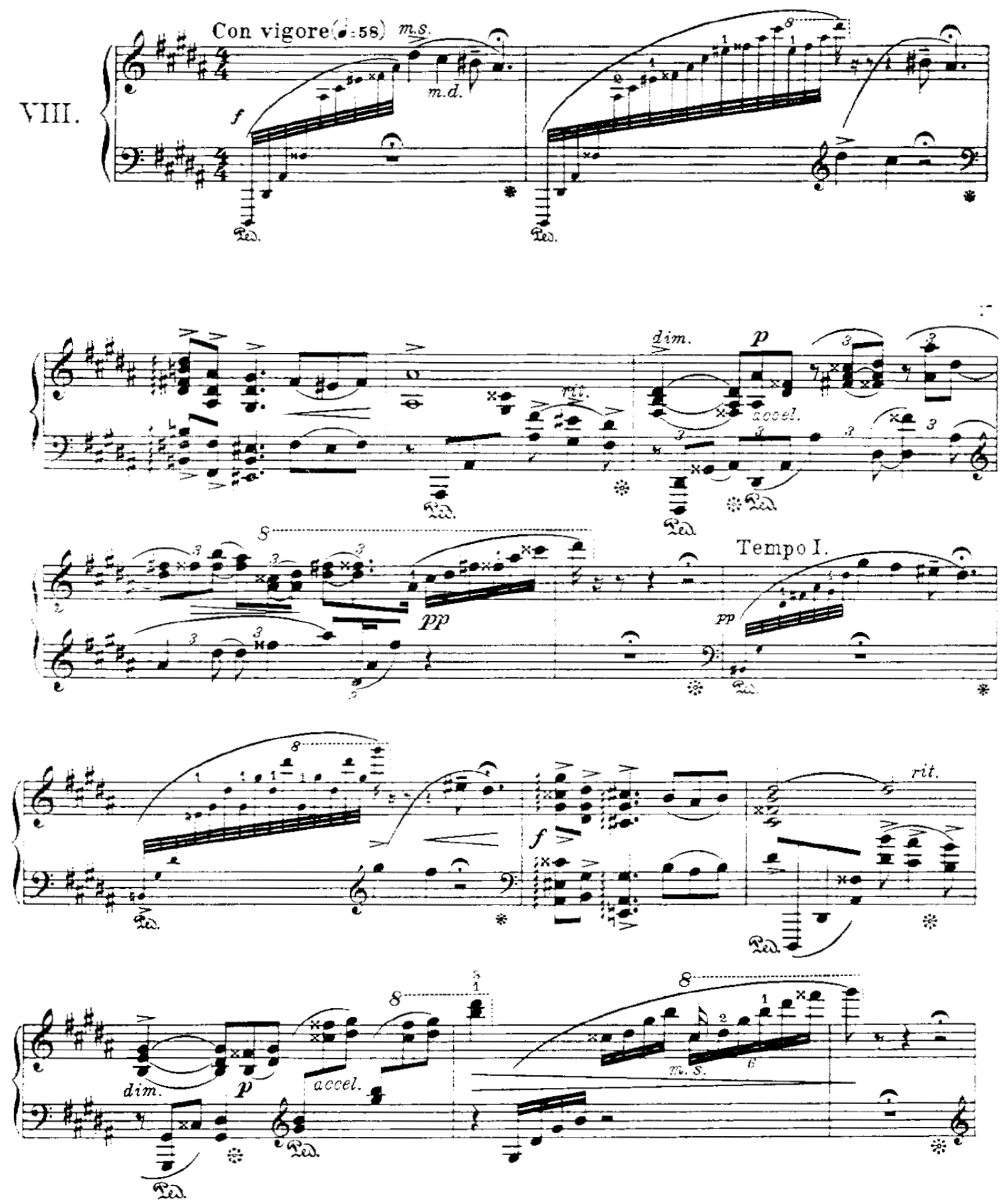

Figure 6.4. Original Version, Var. VIII, Con vigore, mm. 1 - 17. 

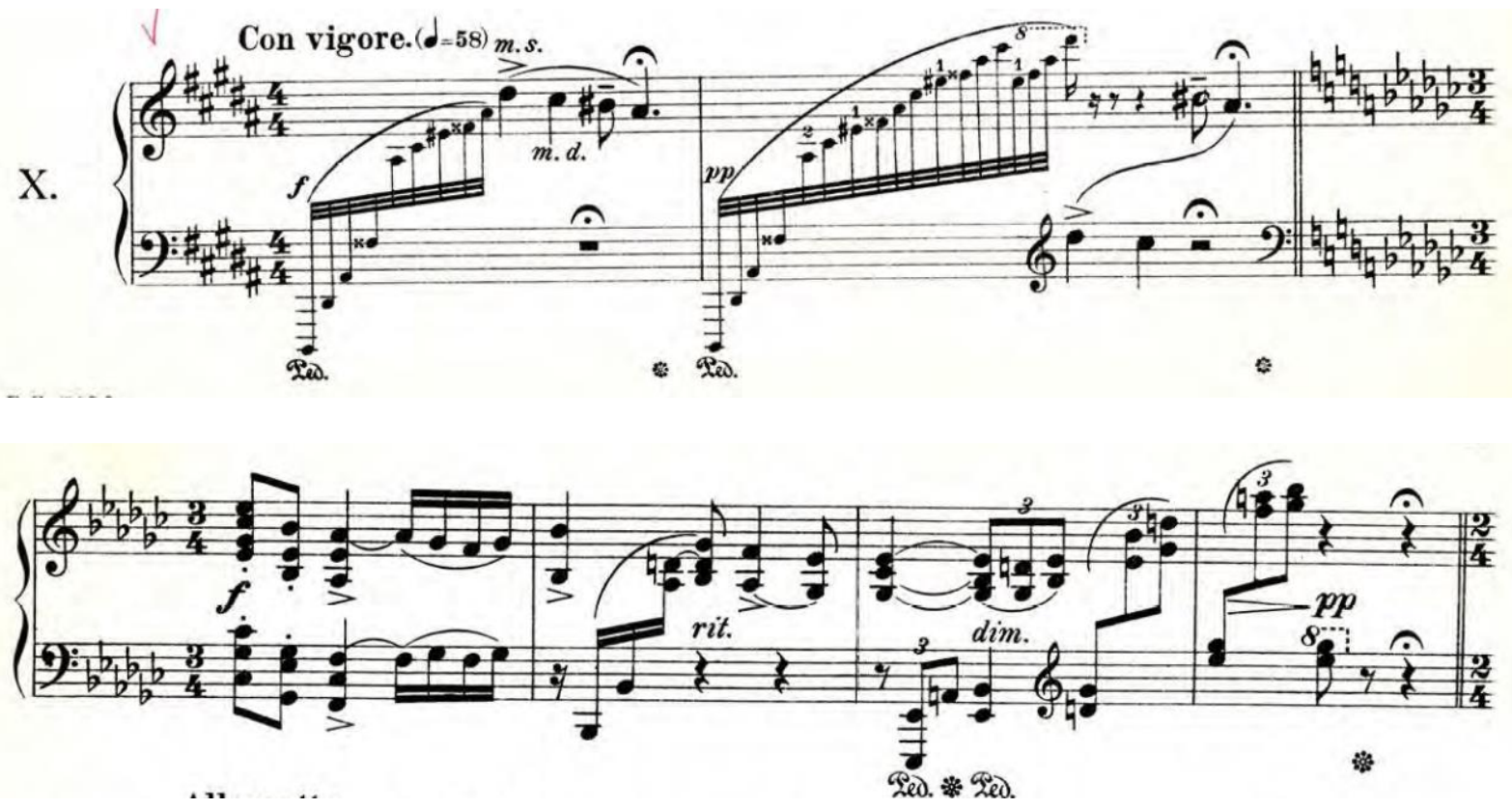

Figure 6.5. Revised Solo Piano Version, Var. X, Con vigore mm. 1 - 6 .

Furthermore, the "Macedonia" theme of Var. $\mathrm{X}$ is in Eb minor in the revised solo piano version, but G\# minor in Var. VIII of the original. The ending section of the revised solo piano version is also in Eb minor; hence, the Eb minor here hints at the new ending key of the revised solo piano version. Additionally, in the original, this "Macedonia" theme is in 4/4, but in the revised solo piano version it is in 2/4. (see Figures 6.6 and 6.7). 

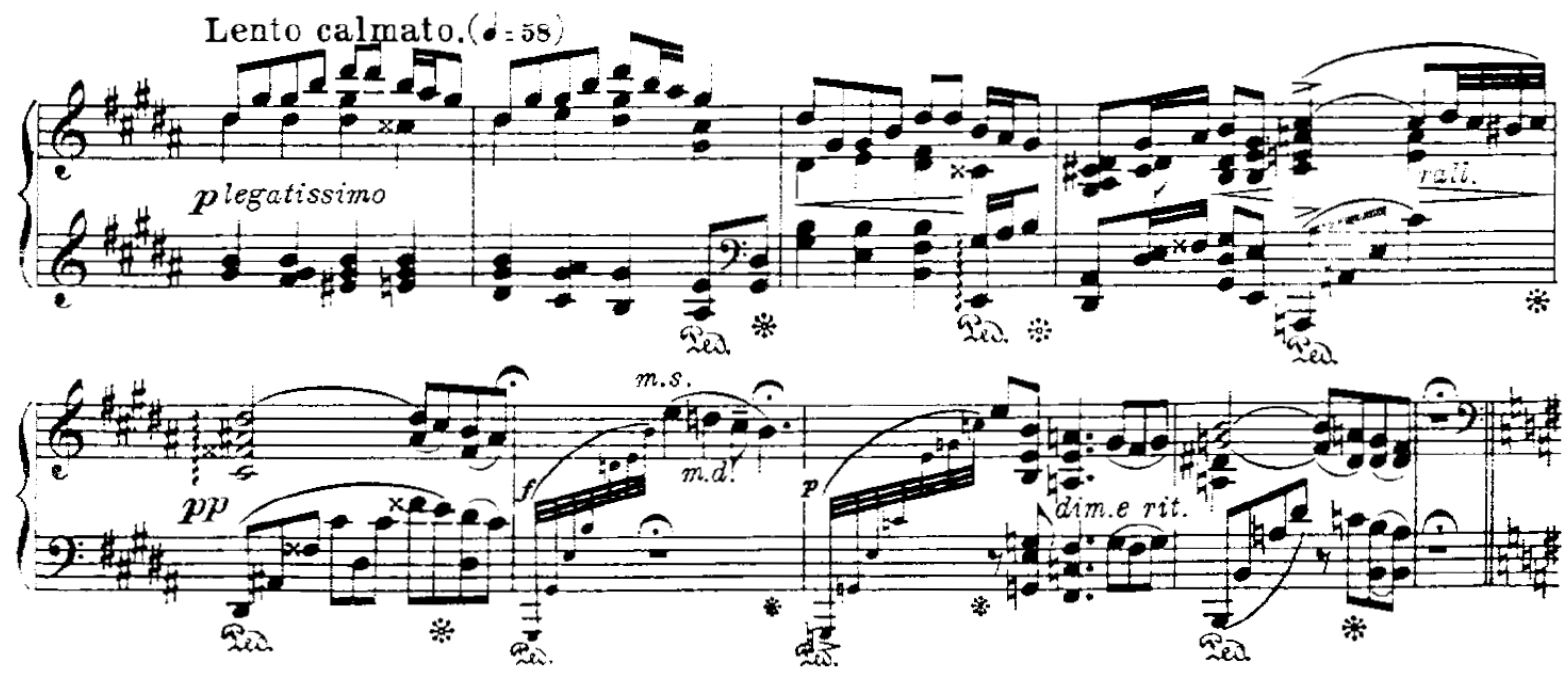

Figure 6.6. Original Version, Var. VIII, mm. 15 - 23.
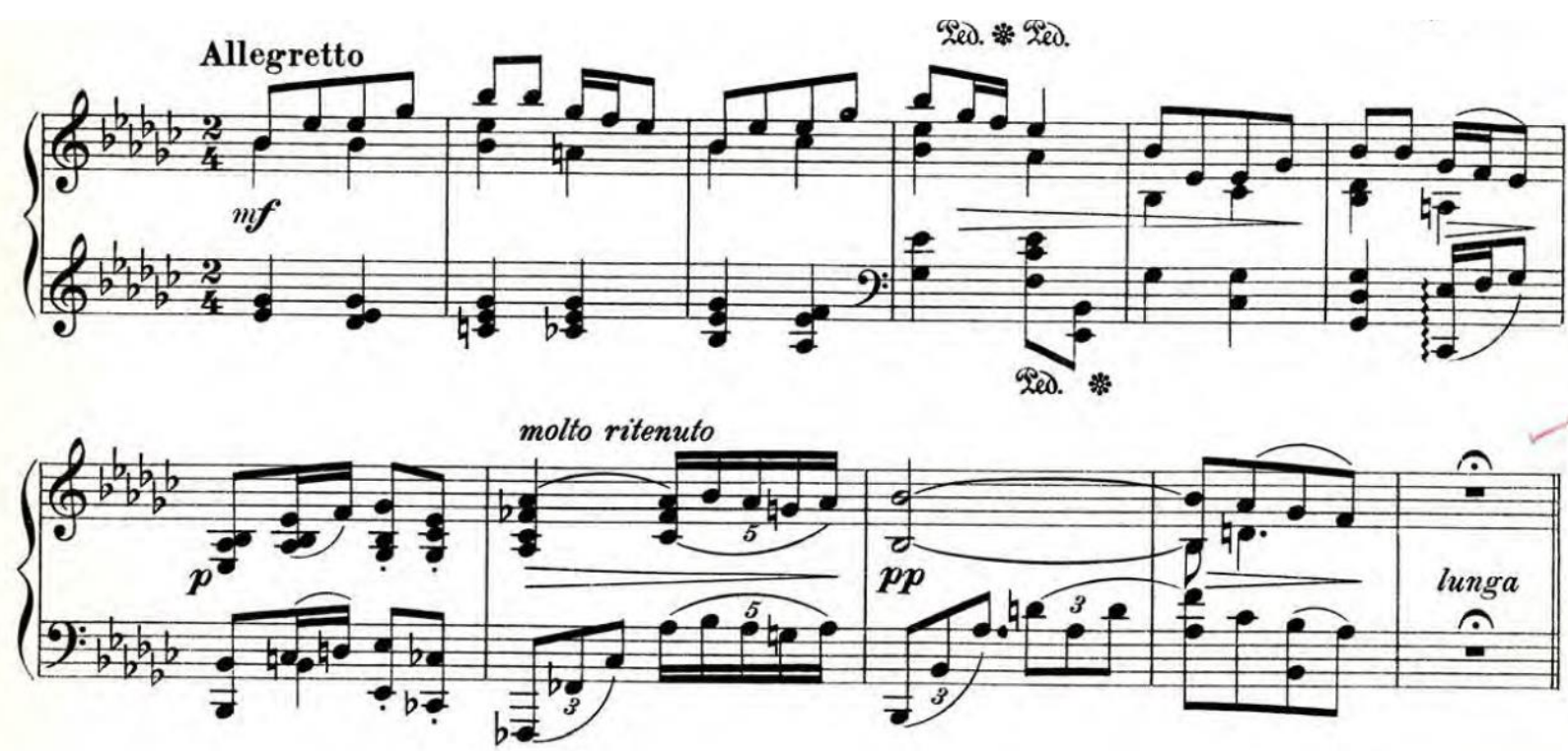

Figure 6.7. Revised Solo Piano Version, Var. X, mm. 7 - 17.

The Marcia funerale section of the revised solo piano version is an exact transposition of the original, from $\mathrm{E}$ minor to Eb minor. However, the revised solo piano version is in $2 / 4$ while the original version is in 4/4 (see Figures 6.8 and 6.9). 
Marcia funerale. $(\cdot=60)$
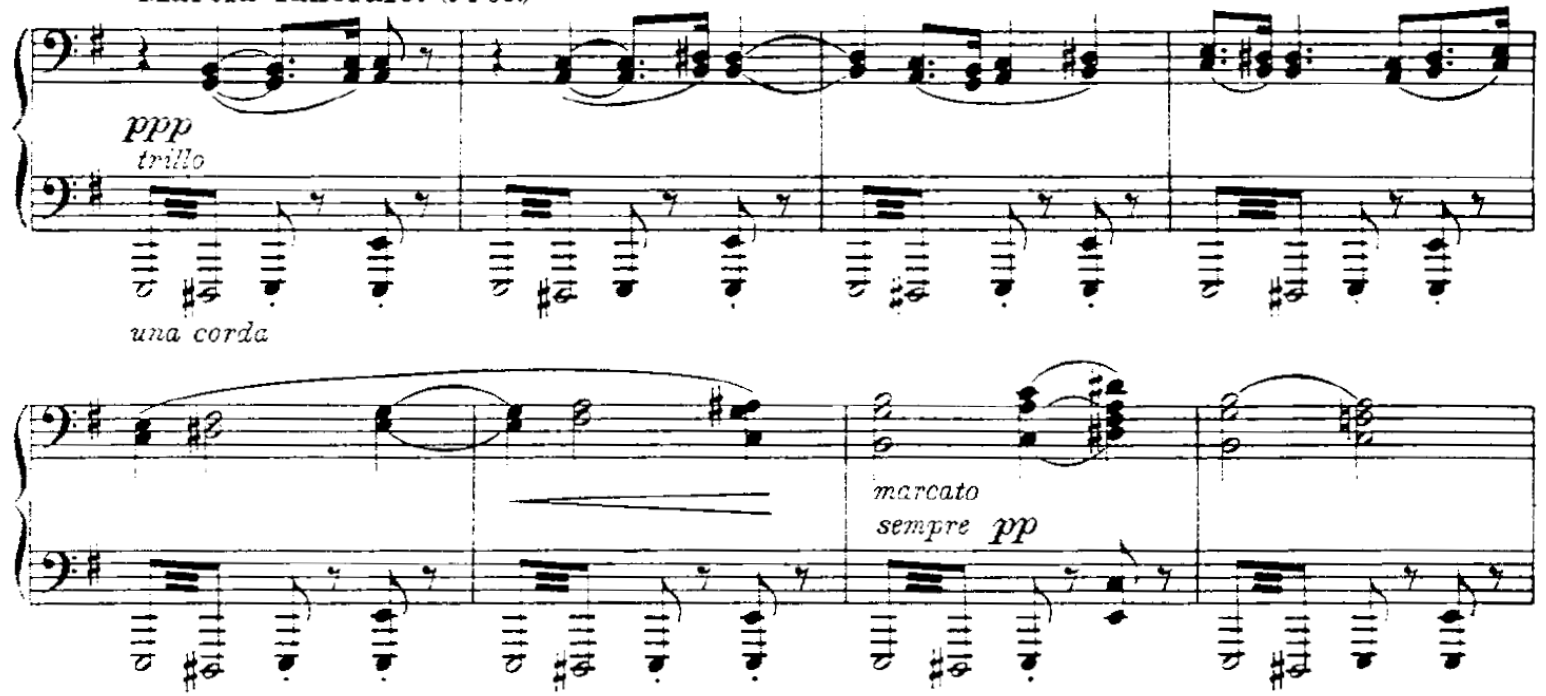

Figure 6.8. Original Version, Var. VIII, Marcia funerale, mm. 24 -- 31.

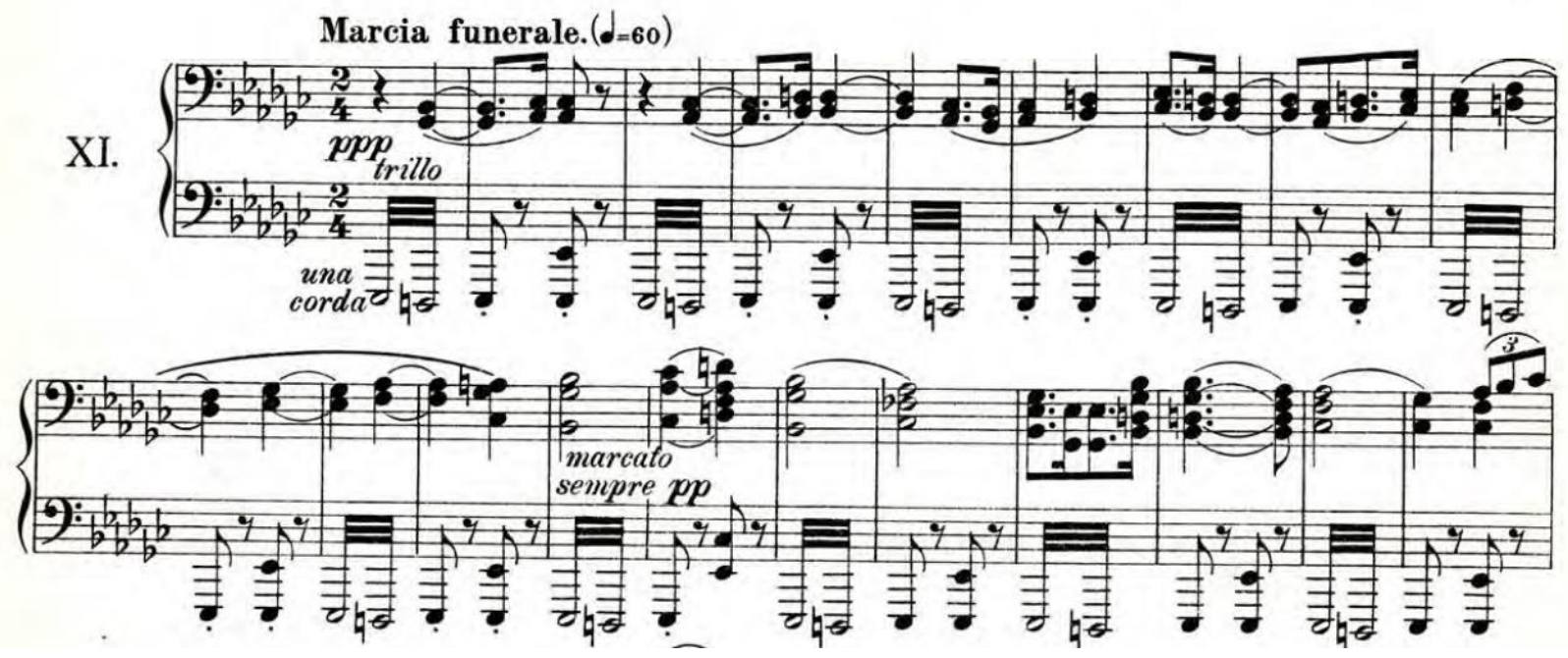

Figure 6.9. Revised Solo Piano Version, Var. XI, Marcia funerale, mm. 1 - 20.

There is no cadenza in the revised solo piano version, and Beach finishes the piece in Eb minor with an Eb major chord at the end to express her sympathy toward the Balkan people.

Overall, the revised solo piano version eliminates all the repeats to make the piece shorter and fit the music style of that time. Because of the elimination of the entire cadenza section, the revised solo piano version is less technically challenging compared to the original solo piano version. Also, in the cadenza section of the original solo piano version, Beach brings back three 
of the four themes and make references to some of the earlier variations. This makes the cadenza not only technically challenging, but also musically coherent as it connects the piece as a whole. Hence, the revised solo piano version sounds less satisfying for some listeners because of the elimination of the cadenza. Nevertheless, the new ending key of the revised solo piano version shows Beach's use of progressive tonality of the late Romantic style more, which also makes the revised solo piano version also very interesting. Therefore, both versions serve their purposes of the musical value of the time. Besides the artistic values of the works, Beach also had to consider the comments from the critics and the market responses. Hence, Beach made the changes in her revised solo piano version to correspond to the music market.

\section{Two-Piano Version}

The 1942 two-piano version is "divided into two portions, leaving duos with the possibility of performing either portion independently of the other, or both together as a set." 99 When the first set is performed alone, the duo plays the theme, Var. I - VIII, then back to the opening theme. When the second set is performed alone, the duo plays the theme, Var. IX - XII, then back to the opening theme. If the duo chooses to perform both sets in the series, they perform the opening theme -- Var. (I - VIII), no opening theme of the second set, and go directly into Var. (IX - XII) - Molto Lento.

The structure of the 1942 two-piano version is very similar to the revised solo piano version. Beach ends both versions with the $\mathrm{Eb}$ major chord instead of the $\mathrm{C \#}$ major chord of the original version. Both versions omit the cadenza section and eliminate repeats. A detailed comparison between the two versions are illustrated on the next page (see Figure 6.10).

\footnotetext{
${ }^{99}$ Hector Valdivia, “Amy Beach (1867-1944)," in Women Composers: Music Through the Ages, Volume 8. Sylvia Glickman and Martha Furman Schleifer, (MI: Thomson Corporation, 1996), 369.
} 


\begin{tabular}{|l|l|}
\hline Revised Solo Piano & Two-Piano \\
\hline Theme (Adagio malincolico) & $\begin{array}{l}\text { First Set } \\
\text { Four measure introduction (Lento expressivo) } \\
\text { Theme -- Tema Dolce }\end{array}$ \\
\hline Variation I & Variation I \\
\hline Variation II & Variation II \\
\hline Variation III (Allegro ma non troppo) & Variation III (Molto Vivace) \\
\hline Variation IV & Variation IV (key signature change) \\
\hline Variation V (Largo con molta espressione) & $\begin{array}{l}\text { Variation V (Adagio con molto expression) - } \\
\text { m. 3, using minor 3rd instead of major third (F } \\
\text { instead of Gb), using enharmonic respelling } \\
\text { of the notes (D instead of Ebb) }\end{array}$ \\
\hline Variation VI -- Quasi Fantasia & $\begin{array}{l}\text { Variation VI - Quasi Fantasia - Allegretto } \\
\text { vigoroso }\end{array}$ \\
\hline Variation VII - Allegro all'Ongarese & Variation VII (Allegro Vivace) \\
\hline Variation VIII - a tempo & Variation VIII (Vivacissimo) \\
\hline & $\begin{array}{l}\text { Second Set } \\
\text { Theme with Intro again }\end{array}$ \\
\hline & $\begin{array}{l}\text { Variation IX (a new variation, does not } \\
\text { appear in the original or the revised versions) }\end{array}$ \\
\hline $\begin{array}{l}\text { Variation IX -- Vivace - Valse lento (poco } \\
\text { rubato) }\end{array}$ & $\begin{array}{l}\text { Variation X - Vivace - Tempo di Valse (non } \\
\text { troppo Allegro }- \text { slightly different at the } \\
\text { ending of the two versions }\end{array}$ \\
\hline $\begin{array}{l}\text { Variation X - con vigore (G\# minor, 4/4- } \\
\text { meter) - Allegretto (Eb minor, 2/4-meter) }\end{array}$ & $\begin{array}{l}\text { Variation XI - Moderato (Eb minor, 2/4- } \\
\text { meter, 3/4 meter), - Allegretto (Eb minor, } \\
\text { 2/4-meter, 3/4-meter) }\end{array}$ \\
\hline Variation XI - Marcia funerale & Variation XII - Marcia funebra \\
\hline Cadenza -- Deleted & Cadenza -- Deleted \\
\hline $\begin{array}{l}\text { Molto lento (Eb minor with Eb major chord at } \\
\text { the end) }\end{array}$ & $\begin{array}{l}\text { Molto lento (Eb minor with Eb major chord at } \\
\text { the end) }\end{array}$ \\
\hline & \\
\hline
\end{tabular}

Figure 6.10. Comparison Between Revised Solo Piano and Two-Piano Versions

The 1942 two-piano version is in two sets, and each set opens with a four-measure introduction before the "O Maiko Moya" theme. Beach distributes the material between the two keyboards and expands the range giving the work an orchestral effect. For example, the lower notes of the second piano are lower than the lower notes of the solo piano versions. Furthermore, in the two-piano version, the melodies are divided between the two pianos. For example, from mm. 5 to 12, Beach gives the first piano the melody, and in mm. 13 through 20, Beach gives the 
second piano the melody. Additionally, the descriptive words are not exactly the same among the different versions. (see Figures 6.11, 6.12, 6.13 and 6.14).

\section{Introduction}

“O Maiko Moya" melody
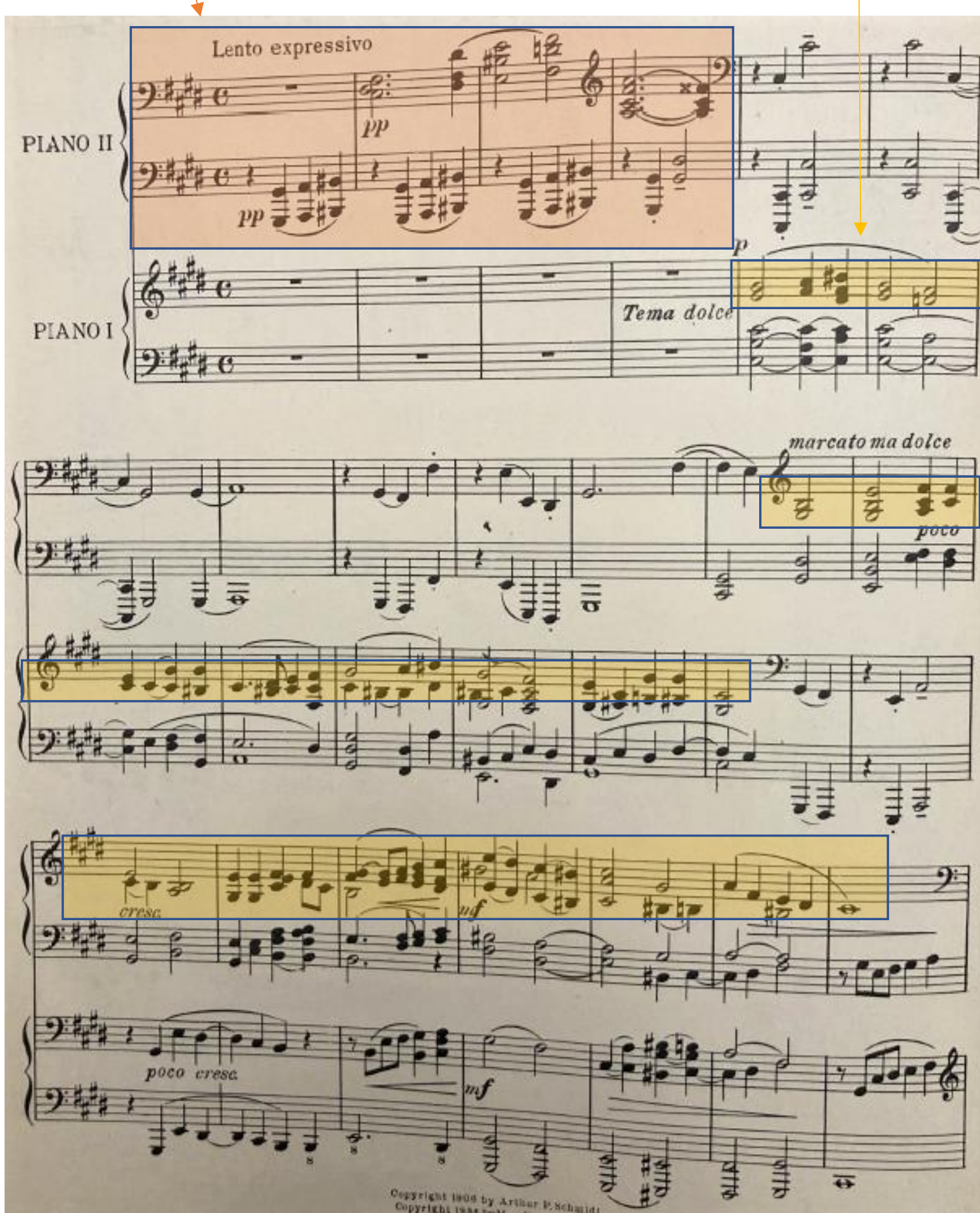

Figure 6.11. Two-Piano Version, Theme, First Set, mm. 1 - 20. 


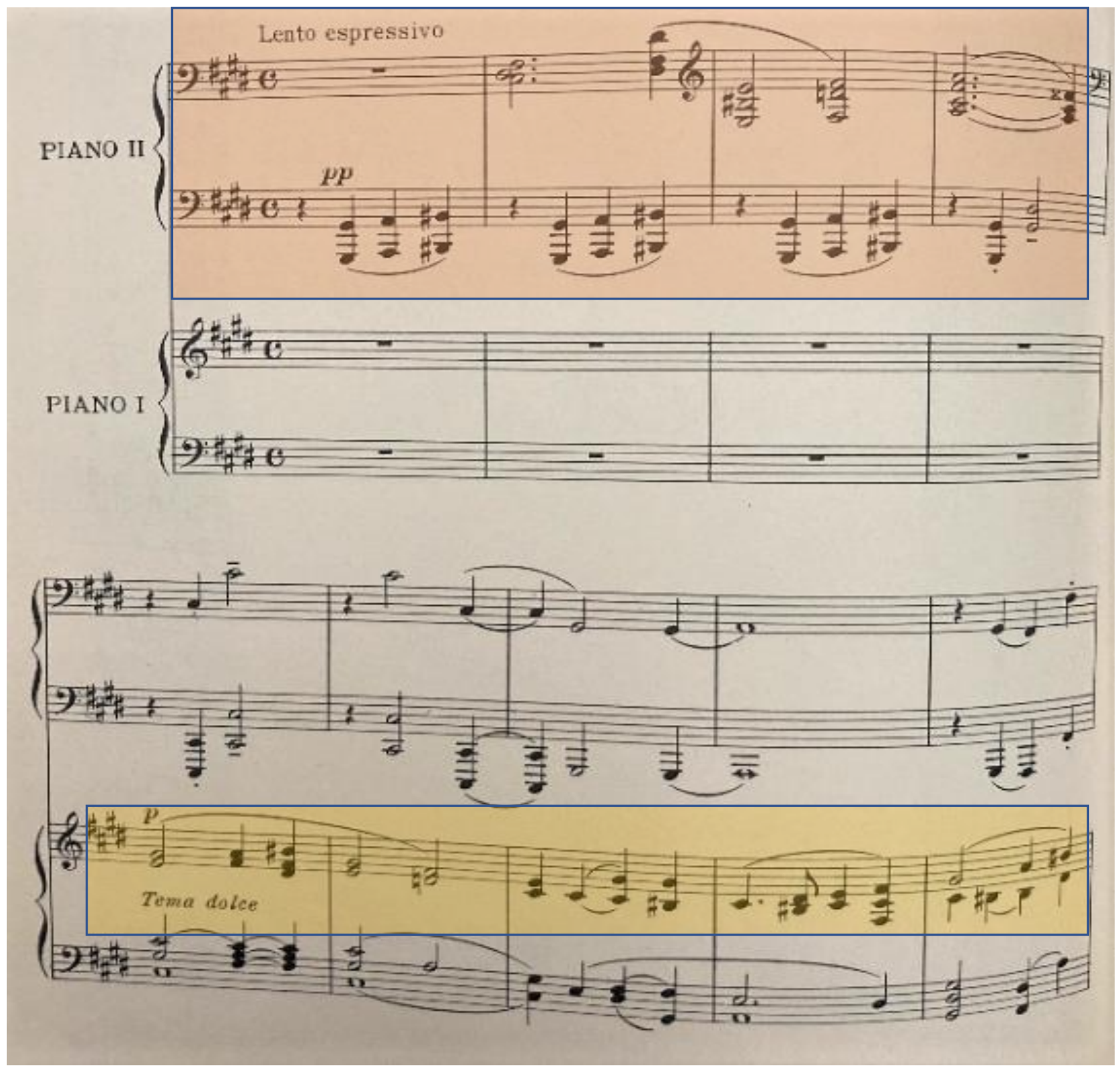

Figure 6.12. Two-Piano Version, Theme, Second Set, mm. 1 - 9. 
Mrs. H. H. A. Beach.

Op. 60.
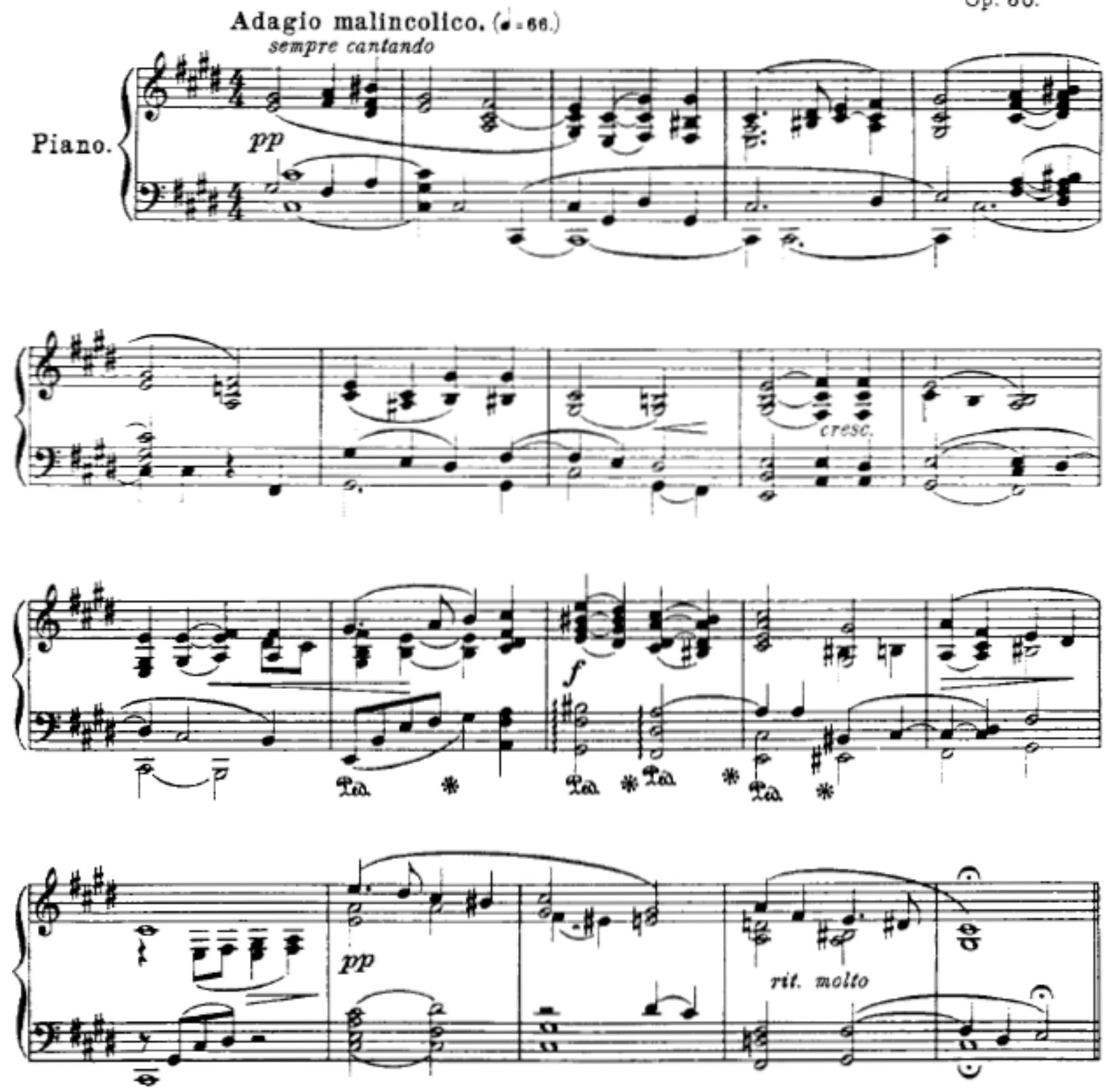

Figure 6.13. Original Solo Piano Version, Theme, mm. 1 - 20. 


\section{variations}

$\underline{\text { Revised Edition }}$

on

\section{Balkan Themes.}

Mrs. H. H. A. Beach.

Op. 60.
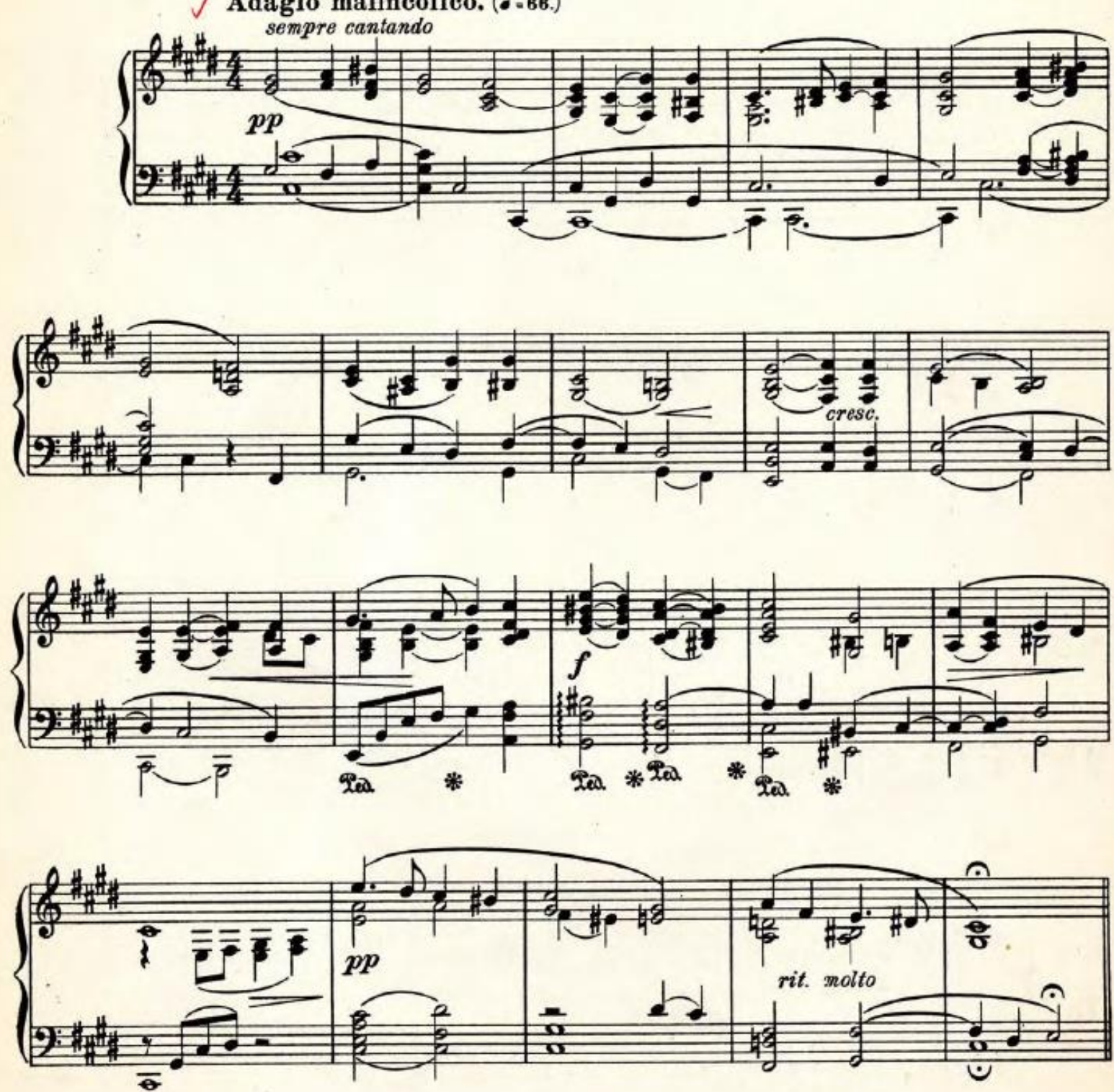

Figure 6.14. Revised Solo Piano Version, Theme, mm. 1 - 20.

There is an interesting key signature change in Variation IV of the two-piano version, but not in the solo piano versions. Also, in the two-piano version, despite Beach's modulation to D 
minor in $\mathrm{m} .9$, the key signature is changed from five flats to two flats instead of one flat. This could imply Bb major which makes it easier to set up the return to Bb minor later (see Figures $6.15,6.16$ and 6.17).

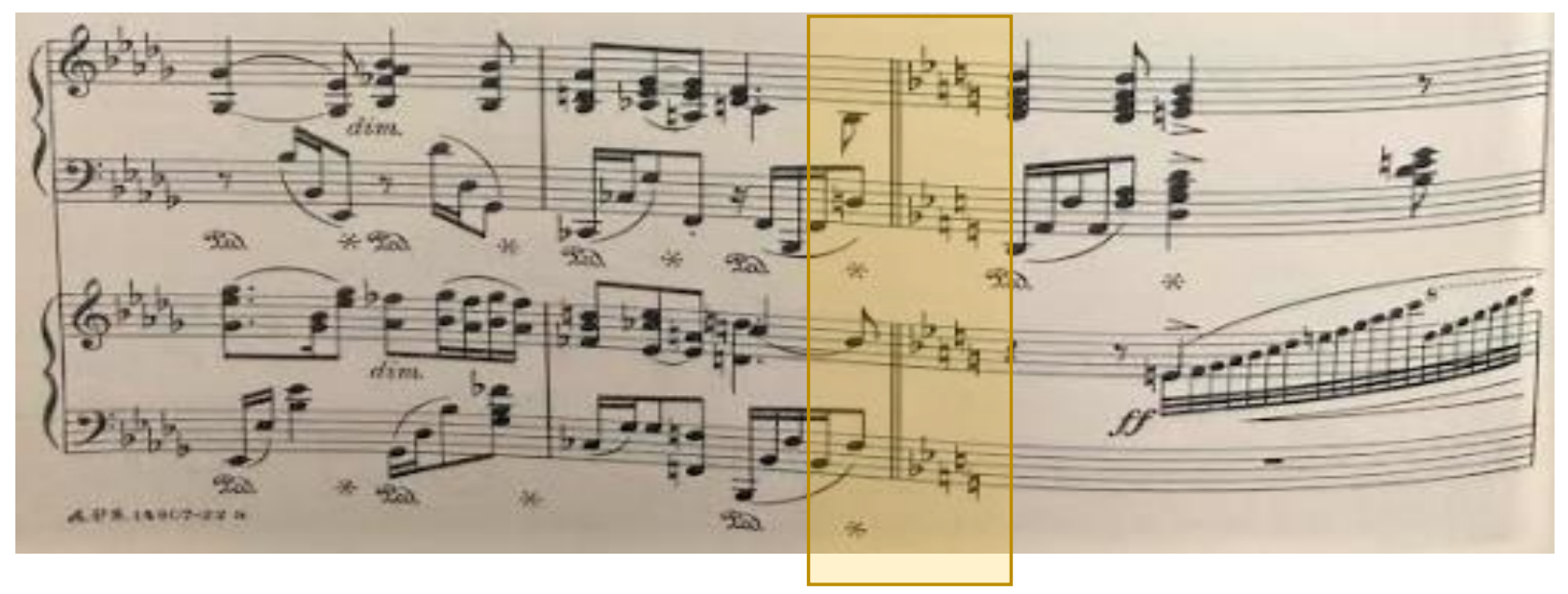

Figure 6.15. Two-Piano Version, Var. IV, mm. 7 -9.

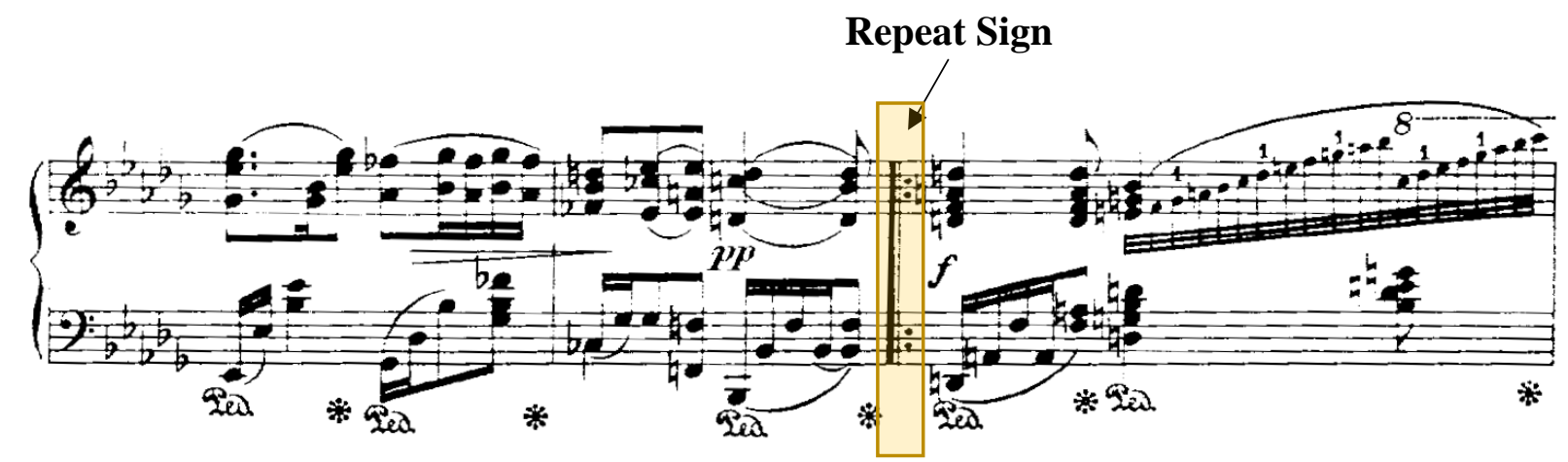

Figure 6.16. Original Solo Piano Version, Var. IV, mm. 7 -9.

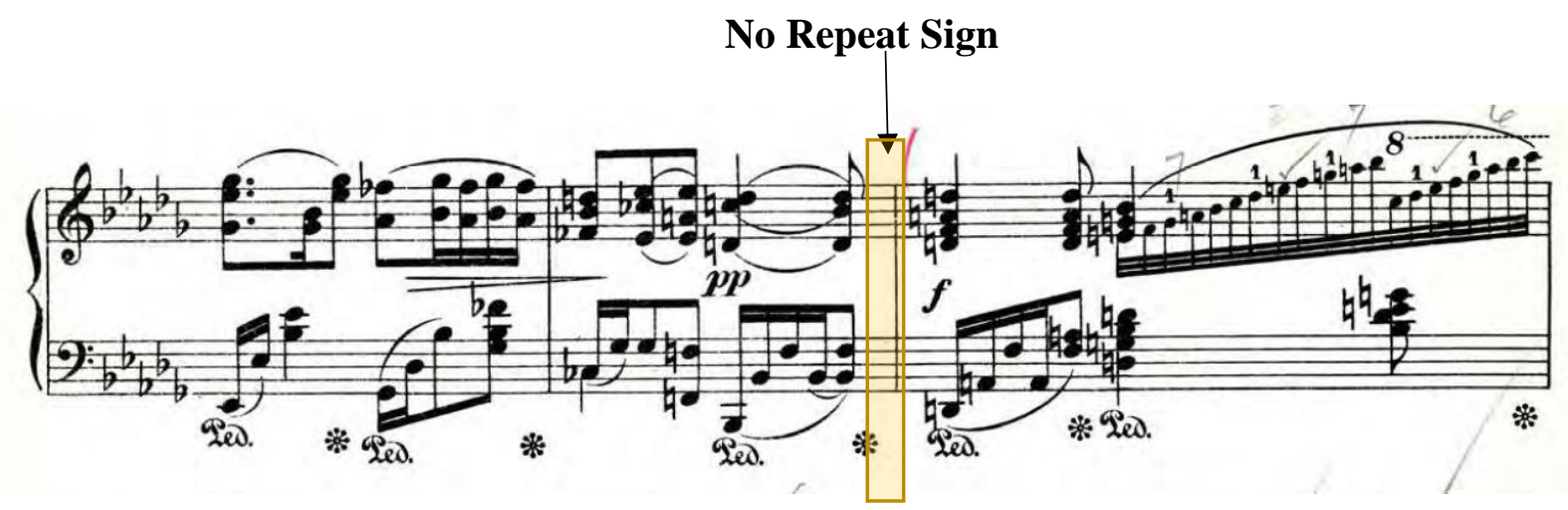

Figure 6.17. Revised Solo Piano Version, Var. IV, mm. 7 -9. 
In the first two measures of Variation $\mathrm{V}$, both the chords and the melody are played alone in the left hand in the solo piano versions, but the chords are played by two hands in the twopiano version. In the third measure, the two-piano version is using a minor $3^{\text {rd }}$ instead of a major $3^{\text {rd }}$ (F instead of $\left.\mathrm{Gb}\right)$. In the same measure, the two-piano version uses $\mathrm{D}$ while the solo piano versions write Ebb. Moreover, the descriptive words and pedal markings are also different among the different versions (see Figures 6.18 and 6.19).

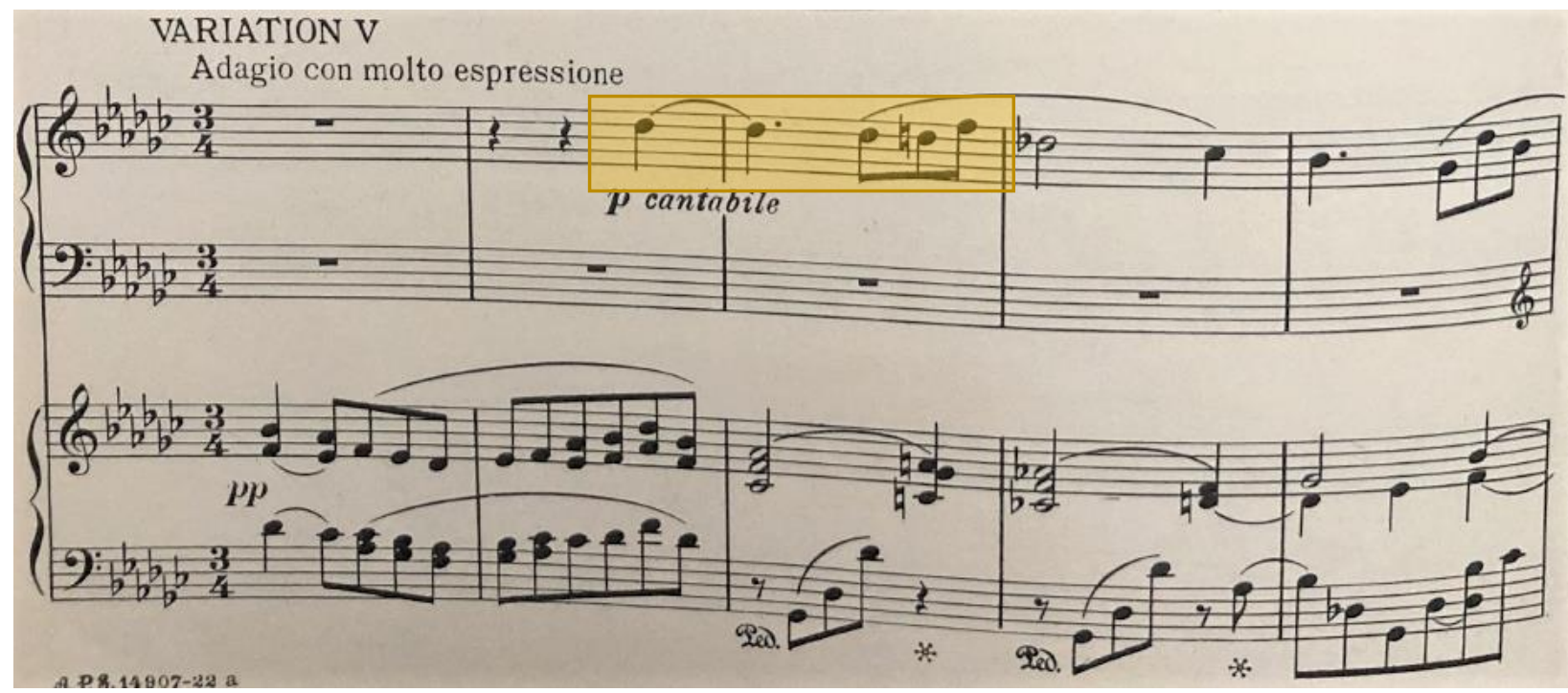

Figure 6.18. Two-Piano Version, Var. V, mm. 1 -5.

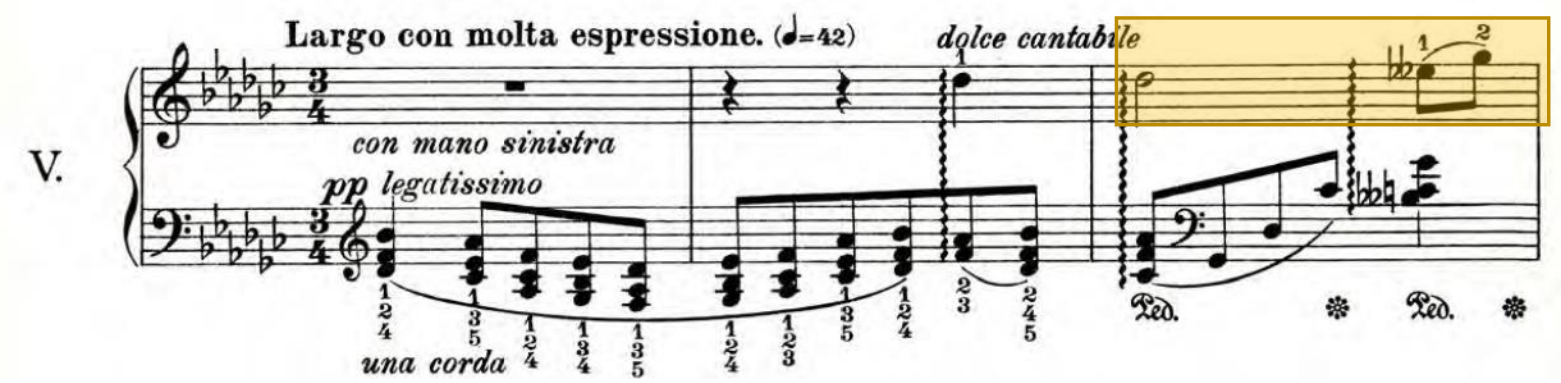

Figure 6.19. Original and Revised Solo Piano Versions, Var. V, mm. 1 -3.

Additionally, some of the fast passages are played by two hands instead of one in the two-piano version; therefore, from the technical aspect, it is slightly easier in the two-piano 
version (see Figures 6.20 and 6.21). Instead of playing fast double thirds by one hand, the twopiano version uses two hands, although it could be done two-handed in the solo version as well.
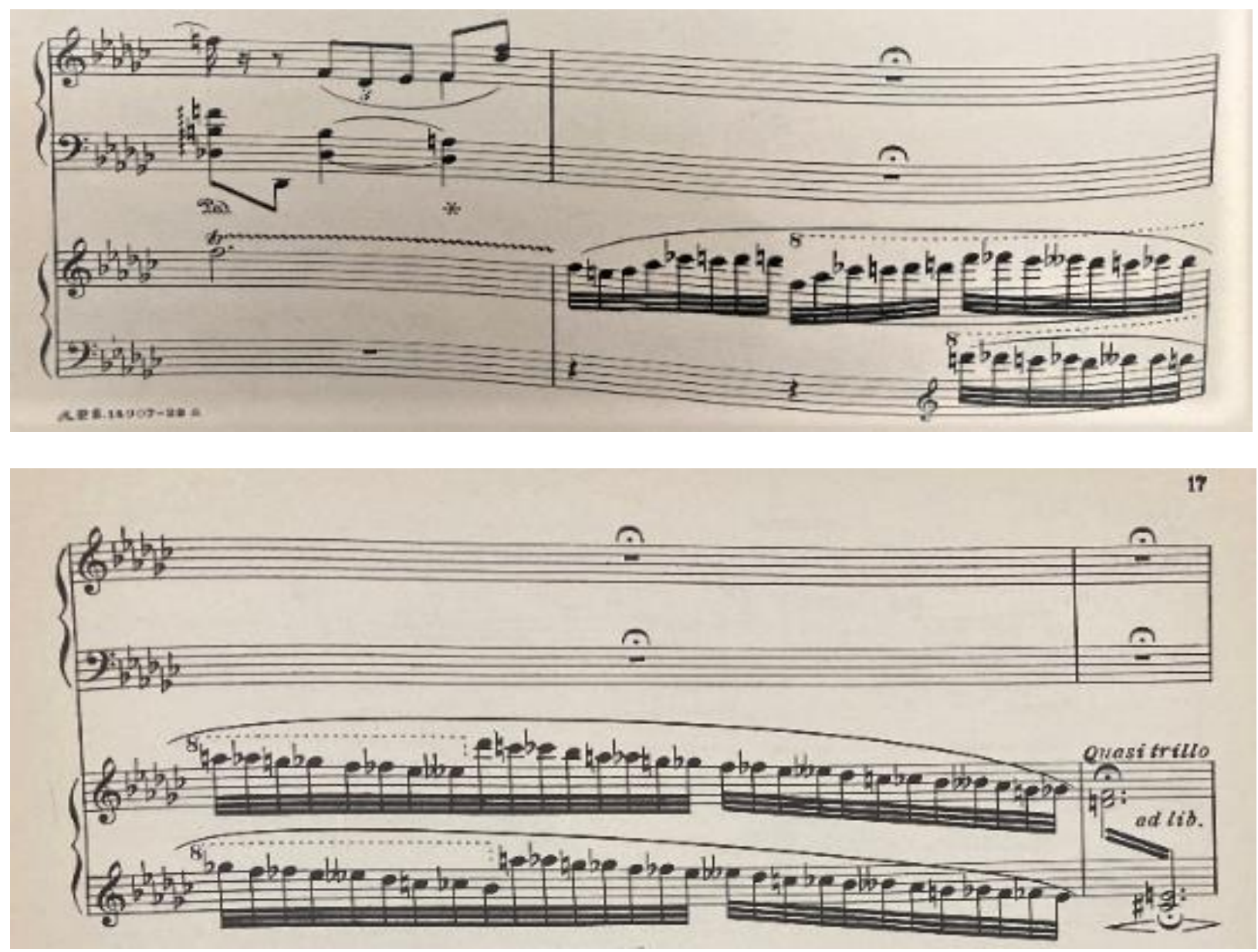

Figure 6.20. Two-Piano Version, Var. V, mm. 38 -41.

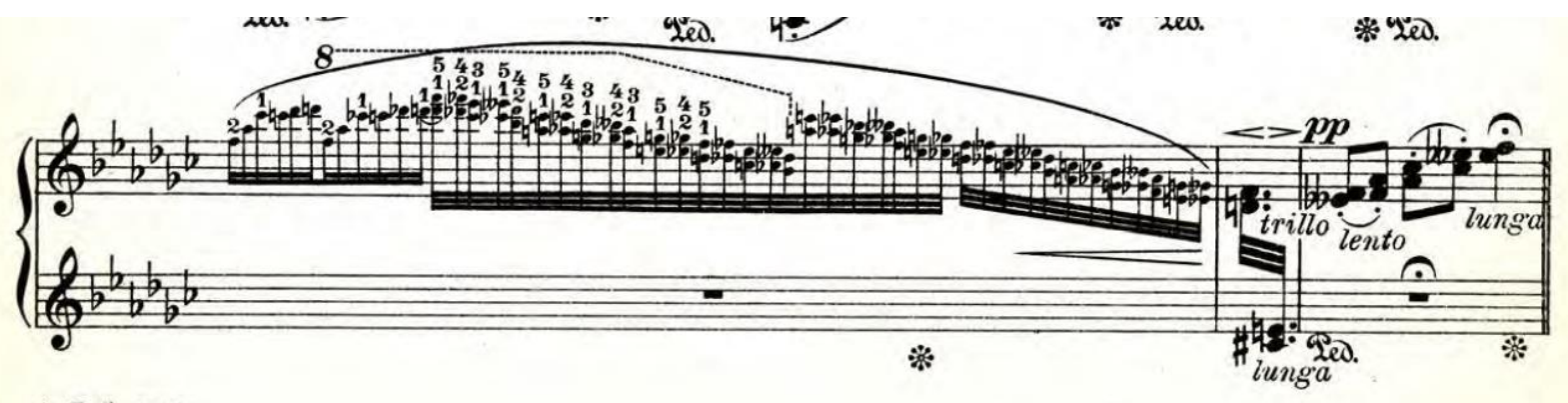

A. P. S. 7196

Figure 6.21. Original and Revised Solo Piano Versions, Var. V, mm. 38 -39. 
Variation X of the two-piano version is Variation VII of the original solo piano version and Variation IX of the revised solo piano version. The endings of the three versions are different. In the two-piano version, the "Macedonia" theme part I is brought back by the second piano at the end. However, the "Macedonia" theme never appears in Variation VII of the original solo piano version or Variation IX of the revised solo piano version (see Figures 6.22, 6.23 and $6.24)$.

"Macedonia" Theme Part I

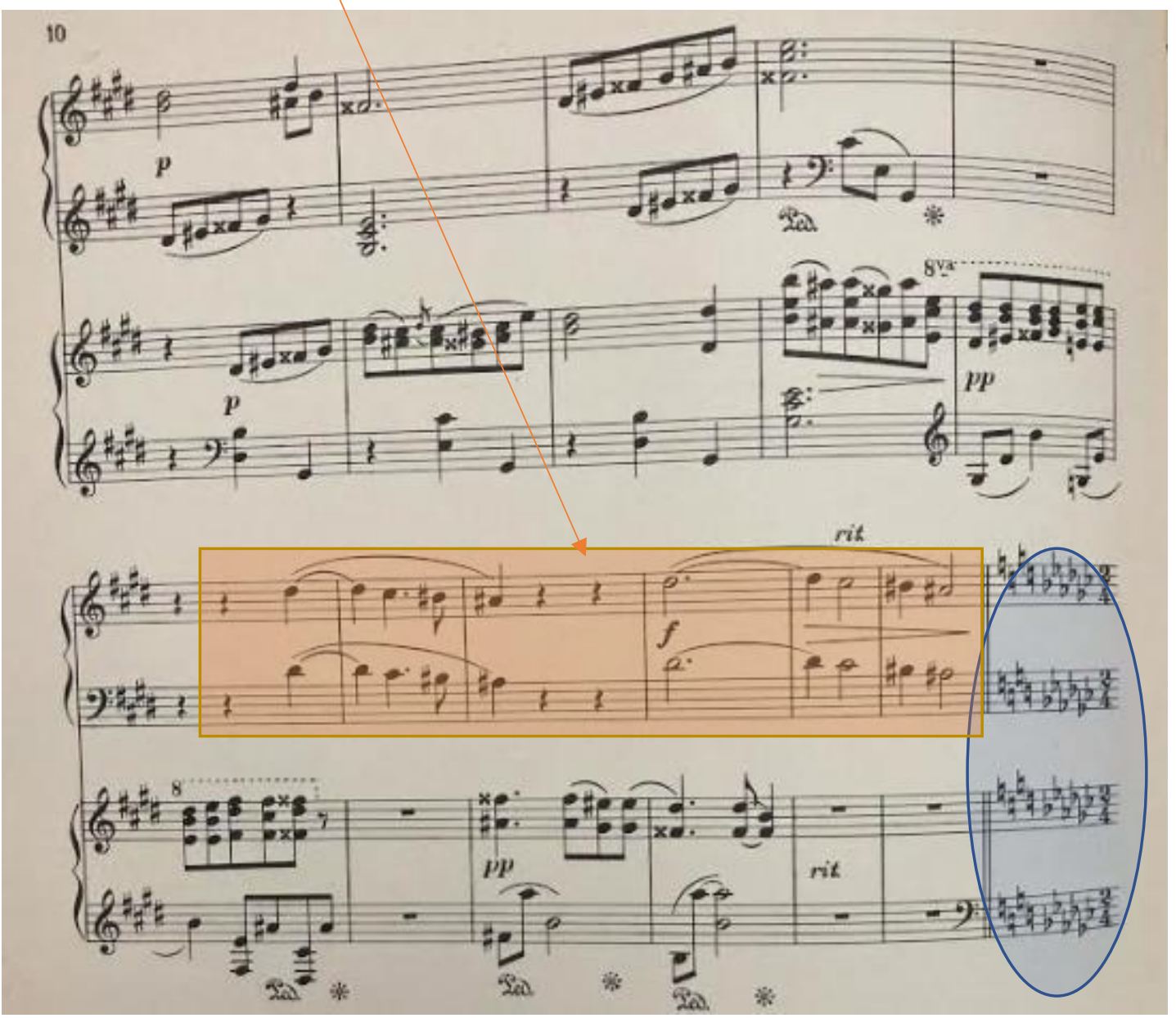

Figure 6.22. Two-Piano Version, Var. X, mm. $37-47$. 


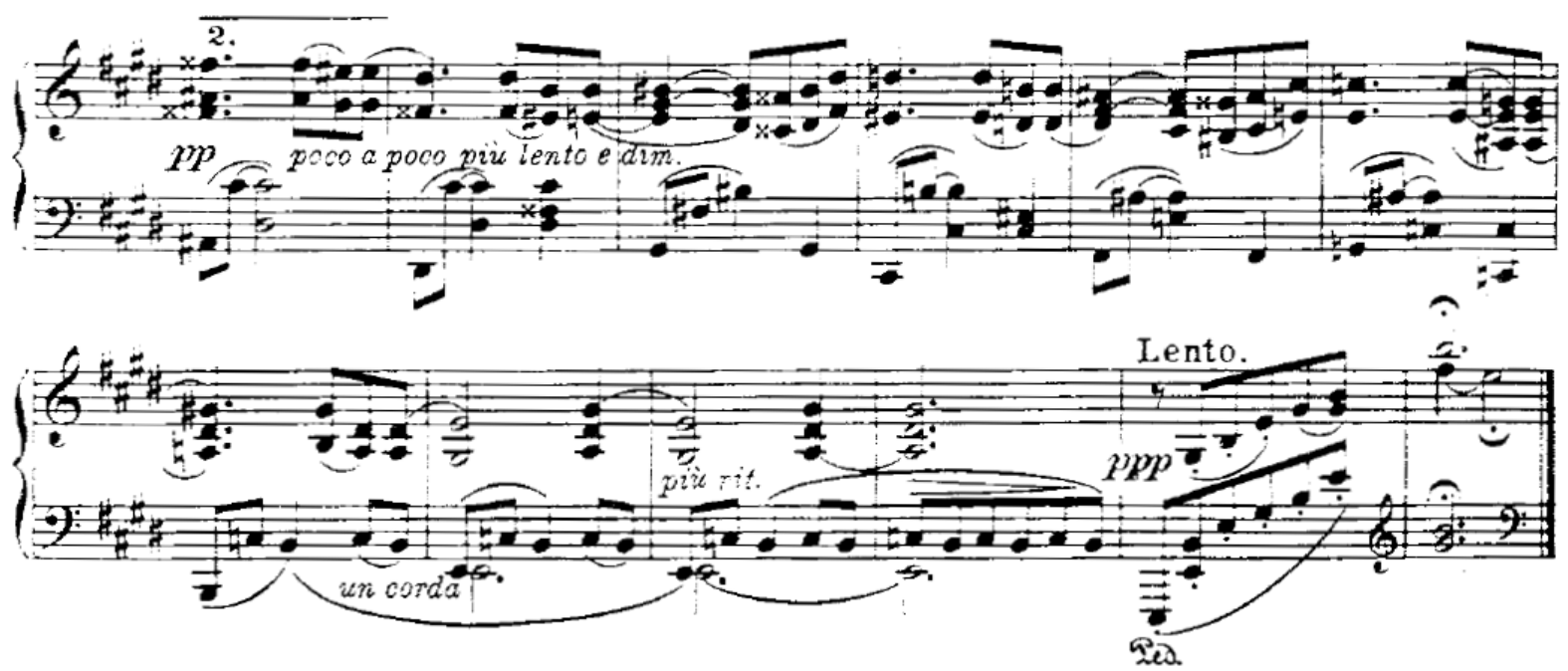

Figure 6.23. Original Solo Piano Version, Var. VII, mm. 36 - 47.

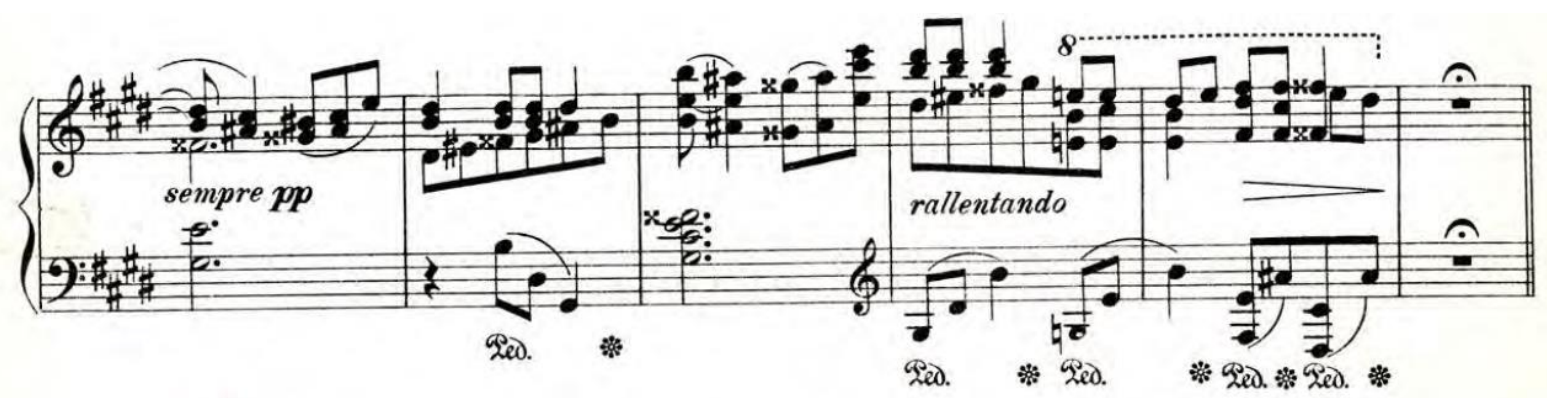

Figure 6.24. Revised Solo Piano Version, Var. IX, mm. 37 - 42.

Furthermore, the return of the "Macedonia" theme part I in Var. X leads to a different key in the opening of Var. XI in the two-piano version. The opening of Var. VIII of the original solo piano version and Var. $X$ of the revised solo piano version are in G\# minor with a 4/4-time signature, but the opening of Var. XI is in Eb minor with a 2/4-time signature in the two-piano version. After this opening, the two-piano version remains in Eb minor and the original solo piano version stays in $\mathrm{G} \#$ minor. However, in the revised solo piano version, Beach uses enharmonic modulations to move from G\# minor to Eb minor (see Figures 6.25, 6.26 and 6.27). 


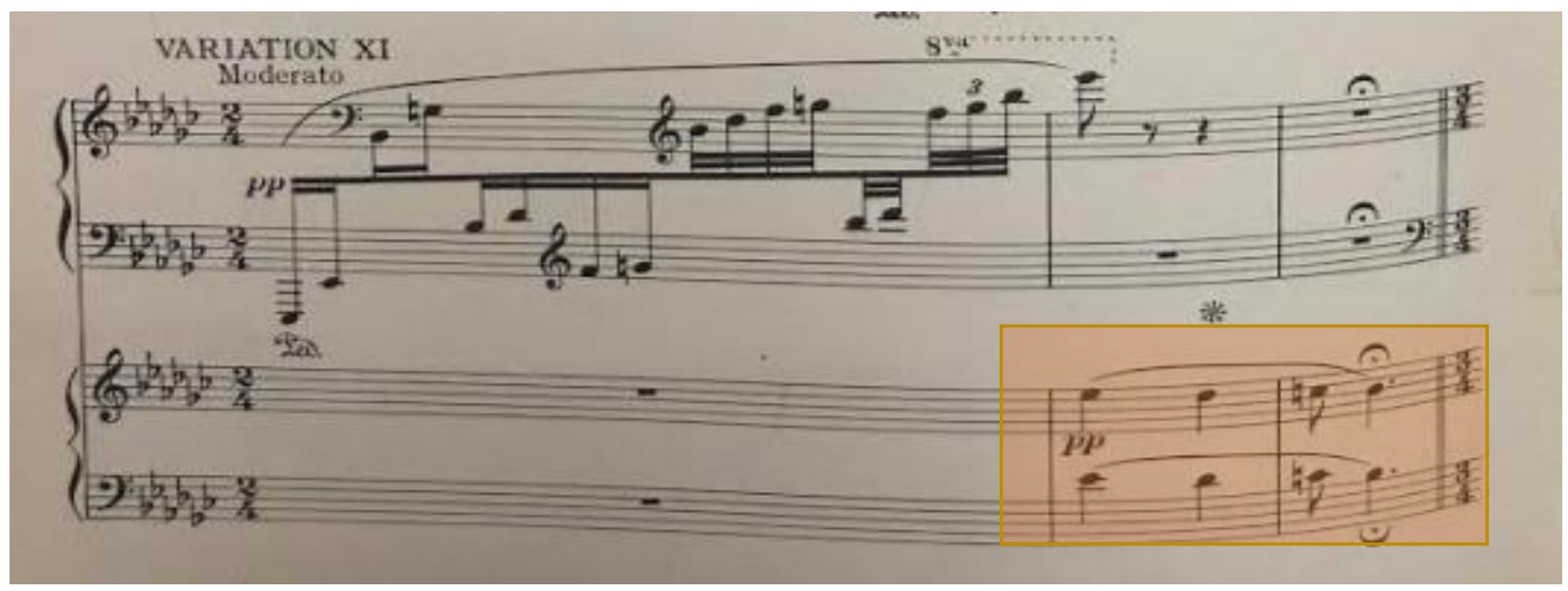

Eb minor

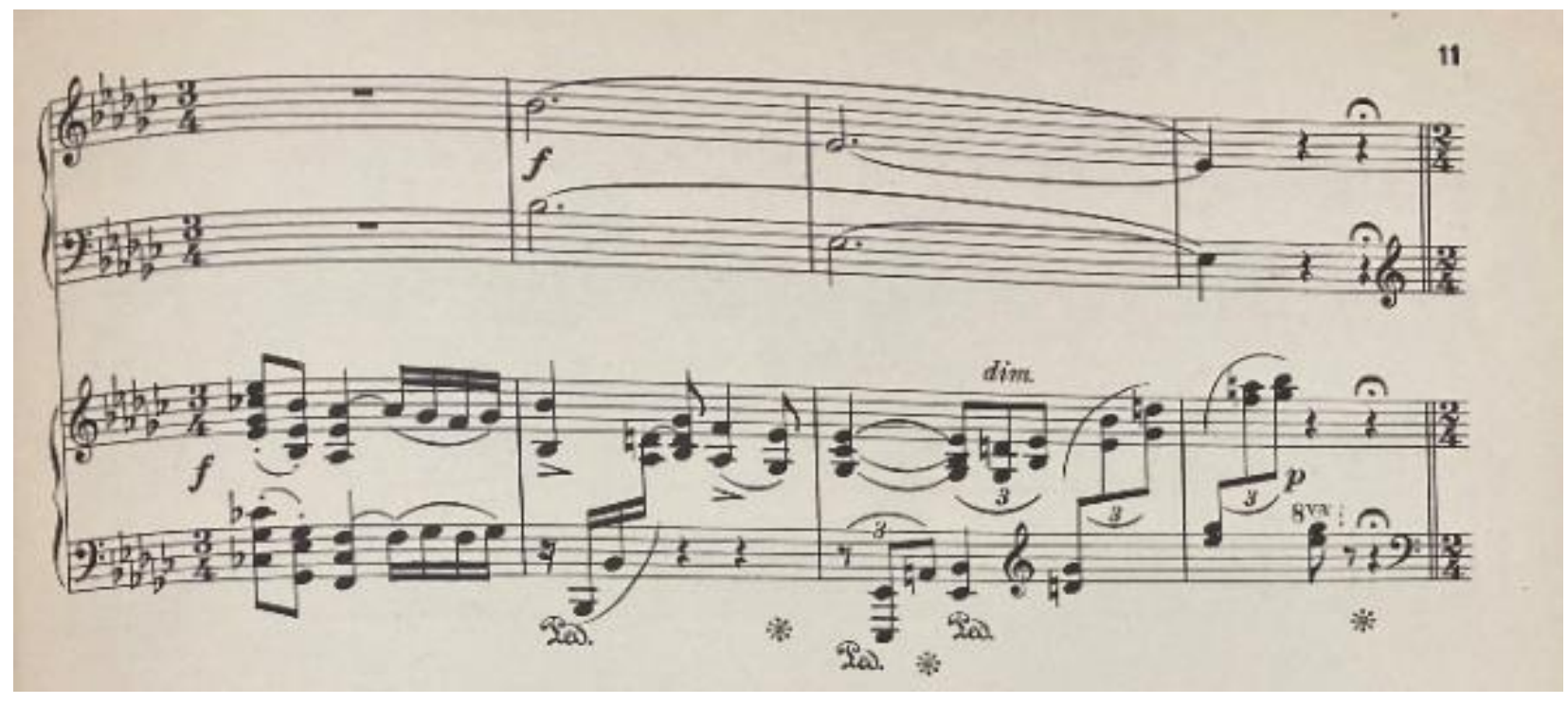

Remains in $\mathrm{Eb}$ minor

Figure 6.25. Two-Piano Version, Var. XI, mm. 1 - 7. 


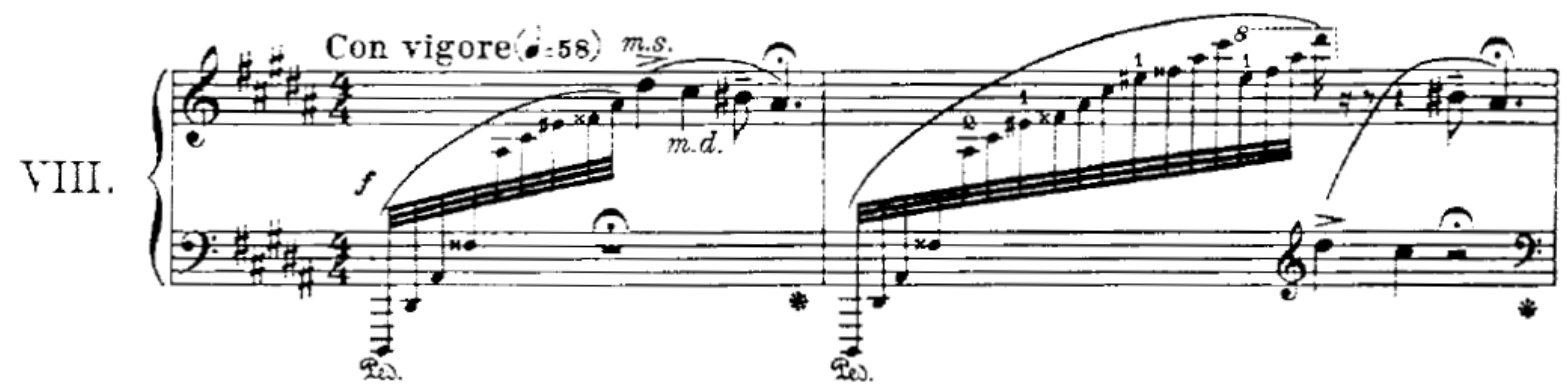

G\# minor

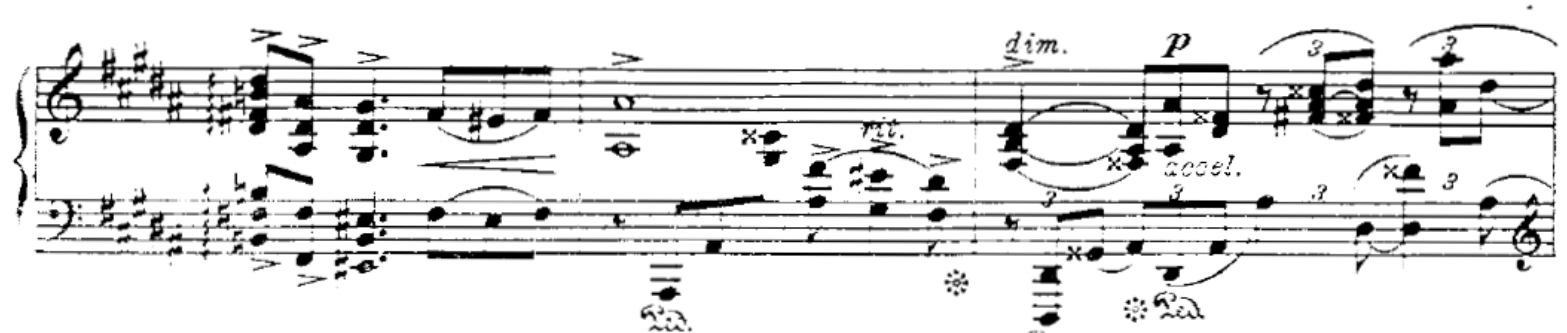

Remains in G\# minor

Figure 6.26. Original Version, Var. VIII, mm. 1 -5.

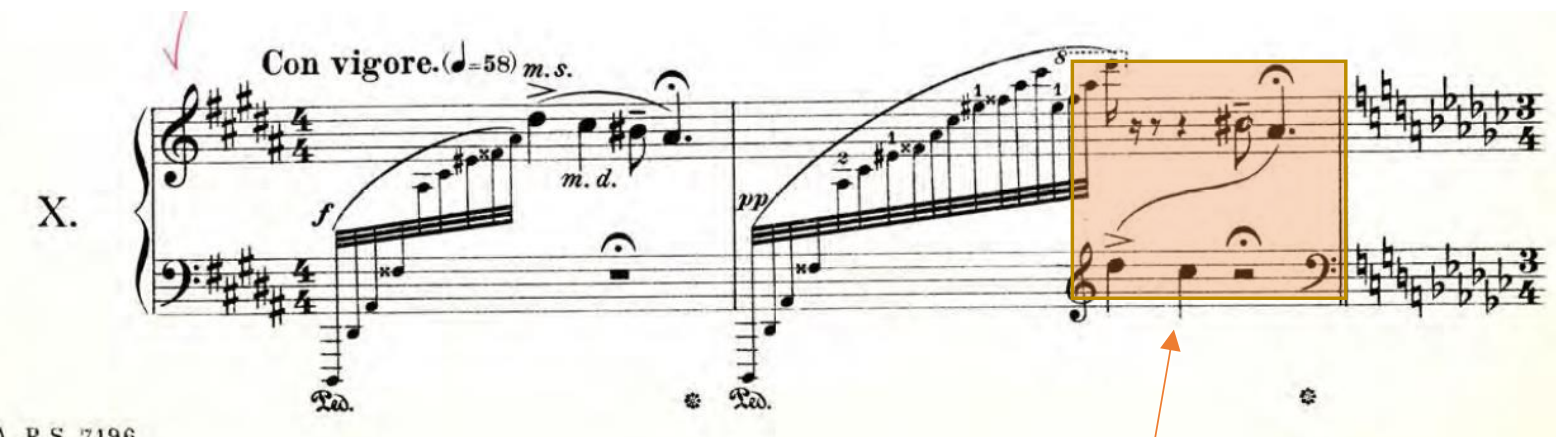

A. P. S. 7196

G\# minor

Enharmonic with mm. $2 \& 3$ of the two-piano version

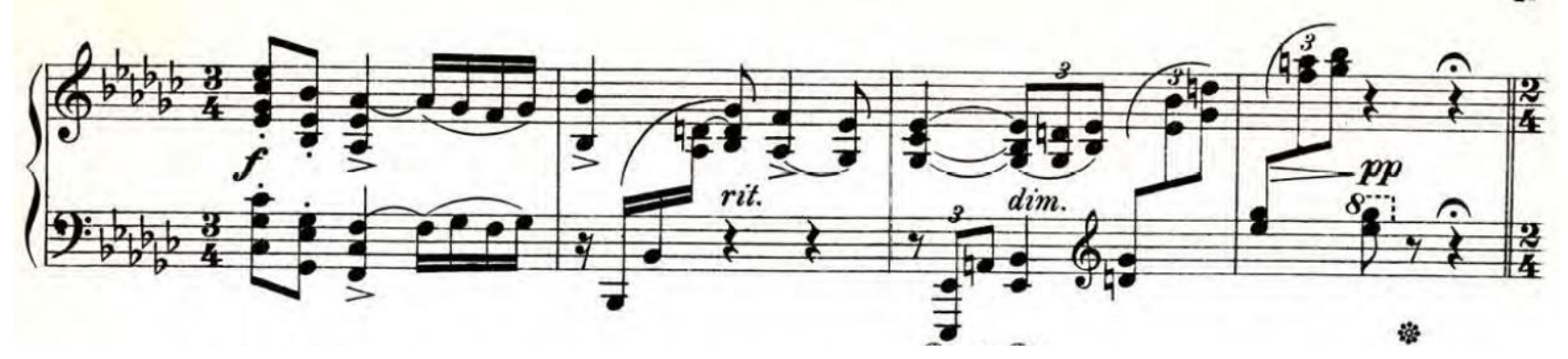

Eb minor

Figure 6.27. Revised Solo Piano Version, Var. X, mm. 1 -6. 
Overall, the two-piano version is more orchestral-like than the solo piano versions due to its range. Technically, it might be easier than the solo piano versions, for it does not have the cadenza section and many of the difficult passages are divided between the two pianos.

However, from the collaborative aspect, it is more challenging. As the two pianos interact, performers must be careful about the ensemble and balance.

\section{Fragmented Orchestral Version}

Beach's orchestral version has existed in manuscript since 1906. Unlike the other three versions, the orchestral version is fragmented. There is only the theme, variation I, variation II, and variation III. Variation III in the orchestral version is similar to variation IX of the two-piano version. This variation only exists in the orchestral and two-piano versions. A detailed comparison between the fragmented orchestral version and the two-piano version is shown below (see Figure 6.28).

\begin{tabular}{|l|l|}
\hline Orchestral & Two-Piano \\
\hline Theme & Intro and Theme \\
\hline Variation I & Variation I \\
\hline Variation II & Variation II \\
\hline Variation III & Variation IX (extra four measures at the end) \\
\hline
\end{tabular}

Figure 6.28. Comparison Between Fragmented Orchestral and Two-Piano Versions

The orchestral version is fragmented, only "fifteen unsigned, undated manuscript pages [survived]." 100 The instrumentation includes "Piccolo/2 Flutes/2 Oboes/English Horn/2 Clarinets in $\mathrm{A} / \mathrm{B}$ ass Clarinet in $\mathrm{A} / 2$ Bassoons; 4 Horns in $\mathrm{F} / 2$ Trumpets in $\mathrm{F} / 2$ Trombones/Bass Trombone/Tuba; Timpani; Harp/Strings." ${ }^{101}$ However, as "no instrumental parts or other records

\footnotetext{
${ }^{100}$ Hector Valdivia, “Amy Beach (1867-1944)," in Women Composers: Music Through the Ages, Volume 8. Sylvia Glickman and Martha Furman Schleifer, (MI: Thomson Corporation, 1996), 369.

${ }^{101}$ Ibid.
} 
of an orchestral version remain, we may never know whether Beach abandoned the orchestration or whether she completed an orchestration that was subsequently lost or destroyed."102

Furthermore, the orchestral version is lacking "tempo markings, dynamics, phrase markings, and articulations, all of which are present in Beach's 1942 manuscript of the twopiano version." 103 Nevertheless, Hector Valdivia made a CD album which includes a full orchestration of this piece. His orchestration is "based on a comparison of the three complete versions of the work as well as an examination of Beach's other works for orchestra, including her Gaelic Symphony and Piano Concerto. These sources provide excellent material for the completion of Beach's orchestration of Variations: notes, rhythms, dynamics, formal organization, instrumentation, articulations, metronome and tempo markings." 104

${ }^{102}$ Hector Valdivia, “Amy Beach (1867-1944),” in Women Composers: Music Through the Ages, Volume 8. Sylvia Glickman and Martha Furman Schleifer, (MI: Thomson Corporation, 1996), 369.

${ }^{103}$ Ibid.

104 Amy Beach, Music by Amy Beach (1867-1944) Variations on Balkan Themes, Moravian Philharmonic Orchestra, conducted by Hector Valdivia, November 28, 2000, CRC 2990, 2009, CD, cover photo notes. 


\section{CHAPTER VII}

\section{Conclusion}

Beach successfully captures the beauty of the Balkan melodies and the spirit of the people in Variations on Balkan Themes. She "achieves a gradual build-up of harmonic and sonic effect without ever sacrificing the balance and symmetry set out in the original theme." ${ }^{105}$ Her expert knowledge of piano writing is explored through her use of pianistic techniques such as rapid thirds, sixths, octaves, leaps, trills, fast passagework and left-hand virtuosity. Her broad use of the piano also helps to create different textures and colors. However, because of the technical difficulties, length, and complex structure, relatively few pianists are able to perform this piece.

Pianists who can play a piece of this technical difficulty also have other choices, such as Ludwig van Beethoven's Diabelli Variations, Johannes Brahms's Variations on a Theme by Handel, and Franz Liszt's Variations on a Theme of Bach. Because Amy Beach is a lesserknown composer, her Variations on Balkan Themes are not performed much. Nevertheless, the unique form, complex harmonies, beautiful melodies, tonal scheme, and virtuosic nature are all valuable aspects of this highly demanding piece. For an emerging pianist in particular, performing this work provides an opportunity to showcase both technical prowess and Beach's fine work.

The original solo piano version of Variations on Balkan Themes is technically demanding, but the piece also exists in one other less technically challenging solo version and a two-piano version, due to the increasing popularity of Beach's music and this work at the time she composed it. The 1936 revised solo piano version eliminates the cadenza and all the repeats

\footnotetext{
${ }^{105}$ Amy Beach, "Variations on Balkan Themes, Op. 60," in Amy Beach Piano Music, ed. by Sylvia Glickman (New York: Da Capo Press, Inc., 1982), introduction.
} 
to make the piece simpler and shorter. The 1942 two-piano version is similar to 1936 revised solo piano version in its structure by eliminating the cadenza and repeats. However, the twopiano version has two sets, and each set begins with the "O Maiko Moya" Theme. The two sets can be performed together or separately. Variation IX in the two-piano version is a new variation which does not exist in either of the solo piano versions.

The fragmented orchestral version only contains the Theme, Variation I, Variation II and Variation III. Nevertheless, Hector Valdivia made a full orchestration of the piece for his recording Music by Amy Beach. ${ }^{106}$ Though it is not completed by Amy Beach herself, Hector Valdivia had carefully studied the three other complete versions and Beach's other orchestral works before he completed the orchestration. Hence, Hector Valdivia's orchestration provides audiences an opportunity to hear this beautiful piece in its orchestral version.

Amy Beach is part of a line of many pianist/composers who have used folk music in their works. Earlier Romantic composers such as Frédéric Chopin (1810-1849) incorporated Polish folk music into much of his piano literature, and Béla Bartók (1881-1945) used Hungarian folk tunes and rhythms in his music. There is a strong connection in using folk music to represent support of a nation or culture.

Variations on Balkan Themes is an important composition that should be played and studied more for its musical value and as a work that gives a more complete picture of American music history. It is a worthy piece for pianists to explore for its musical and cultural values.

\footnotetext{
106 Amy Beach, Music by Amy Beach (1867-1944) Variations on Balkan Themes, Moravian Philharmonic Orchestra, conducted by Hector Valdivia, November 28, 2000, CRC 2990, 2009, CD, cover photo notes.
} 


\section{APPENDIX: SELECTED LIST OF RECORDINGS AND EDITIONS}

\section{Recordings}

Beach, Amy. Amy Beach Piano Music, Volume Two, the Turn of the Century. Kirsten Johnson. GMCD 7329, 2009, CD.

_ _ _. By the Still Waters: The Solo Piano Music of Amy Beach, volume one. Joanne Polk. Arabesque Recordings Z6693, 1997, CD.

_ _ _. Three American Romantics. Mary Louise Boehm. Albany Records Troy 293, 1998, CD.

_ _ _. Variations on Balkan Themes Op. 60, (revised in 1936). Eunhae Choi. Performed April 3, 2020. video, 19:48. https://www.youtube.com/watch?v=v4bW9nie6q0.

_ _ _. Variations on Balkan Themes, Op. 60c for Two Pianos (1937). Kathryn Ananda Owens, Piano I; Christopher Atzinger, Piano II. CRC 2990, August 25, 2006. https://wvuwl-naxosmusiclibrarycom.wvu.idm.oclc.org/streamw.asp?ver=2.0\&s=139677\%2FWVUWLNmlPd12\%2F101 $\underline{3416 .}$.

_ _ _. Variations on Balkan Themes, Op. 60d for Orchestra (1906/2000). Moravian Philharmonic Orchestra. Hector Valdivia. CRC 2990, November 28, 2000. https://wvuwl-naxosmusiclibrarycom.wvu.idm.oclc.org/streamw.asp?ver=2.0\&s=139677\%2FWVUWLNmlPd12\%2F101 $\underline{3478}$.

\section{Editions}

Beach, Amy. Piano Music of Amy Beach. Milwaukee, WI : Hal Leonard Corporation, 2013.

_- . "Variations on Balkan Themes, Op. 60." In Amy Beach Piano Music, edited by Sylvia Glickman, 58 - 83. New York: Da Capo Press, Inc., 1982.

- - - Variations on Balkan Themes: Op. 60: for Piano. Boston: The Arthur P. Schmidt Co., 1936.

- - - Variations on Balkan Themes for Pianoforte. Boston: The Arthur P. Schmidt Co., 1942.

Valdivia, Hector. "Amy Beach (1867-1944).” In Women Composers: Music Through the Ages, Volume 8, edited by Sylvia Glickman and Martha Furman Schleifer, 369 - 395. MI: Thomson Corporation, 1996. 


\section{BIBLIOGRAPHY}

"Balkan Aspirations - this map from 1914 illustrates the territorial ambitions of 4 nations: Bulgarians, Greeks, Romanians and Serbs.” Digital Image. Reddit. March 15, 2021. https://legacy.lib.utexas.edu/maps/historical/balkan_aspirations_1914.jpg

Beach, Amy Marcy Cheney. Amy Marcy Cheney Beach Music for Piano. Edited by Sylvia Glickman. PA: Hildegard Pub. Co., 1994.

- - " "Variations on Balkan Themes, Op. 60." In Amy Beach Piano Music, edited by Sylvia Glickman, 58 - 83. New York: Da Capo Press, Inc., 1982.

- - -. Variations on Balkan Themes for Pianoforte. Boston: The Arthur P. Schmidt Co., 1942.

. Music by Amy Beach. Moravian Philharmonic Orchestra. Hector Valdivia. CRC 2990, November 28, 2000. https://wvuwl-naxosmusiclibrarycom.wvu.idm.oclc.org/streamw.asp?ver=2.0\&s=139677\%2FWVUWLNmlPd12\%2F101 $\underline{3478 .}$.

Bellman, Jonathan. "Verbunkos." Grove Music Online. 2001; Accessed 11 Oct. 2020. https://www.oxfordmusiconline.com/grovemusic/view/10.1093/gmo/9781561592630.001 .0001/omo-9781561592630-e-0000029184.

Block, Adrienne Fried. Amy Beach, Passionate Victorian: The Life and Work of an American Composer, 1867-1944. New York: Oxford University Press, 1998.

- - - "Amy Beach's Music on Native American Themes." American Music 8, No. 2 (1990): 141 - 66. doi:10.2307/3051947.

Bomberger, E. Douglas. "Motivic Development in Amy Beach's Variations on Balkan Themes, Op. 60." American Music 10, No. 3 (1992): 326-47. doi:10.2307/3051598.

Bomberger, E. Douglas, and Adrienne Fried Block. "On Beach's Variations on Balkan Themes, Op. 60." American Music 11, No. 3 (1993): 368-71. doi:10.2307/3052509.

Botsford, Florence Hudson. Folk Songs of Many Peoples: With English Versions by American Poets. New York: The Womans Press, 1921.

Brown, Jeanell Wise. Amy Beach and Her Chamber Music: Biography, Documents, Style. N.J.: Scarecrow Press, 1994.

Burnaman, Stephen Paul. "The Solo Piano Music of Edward MacDowell and Mrs. H.H.A. Beach: A Historical Analysis.” DMA diss., University of Texas-Austin, 1997. 
Elson, Louis C. "American Women in Music.” In the History of American Music. Rev. ed., 293 - 310. New York: Macmillan, 1915, 1925. Reprint, New York: Burt Franklin. 1971.

Knowledgia. "The First Balkan War." May 29, 2019. video, 10:30. https://www.youtube.com/watch?v=0LvLr1UjCVw.

Leichtentritt, Hugo. “Theme and Variations.” In Musical Form, 95 - 109. Cambridge: Harvard University Press, 1951.

Nation, R. Craig. "The Balkan Region in World Politics." In War in the Balkans, 19912002, 1- 42. PA: Strategic Studies Institute, US Army War College, 2003. Accessed October 4, 2020. http://www.jstor.org.www.libproxy.wvu.edu/stable/resrep12133.5.

Sun, Jiaqi. "The Mediant Relations in Amy Beach's Variations on Balkan Themes, Op. 60." MA thesis, Kent State University, 2020.

Tuthill, Burnet C. "Mrs. H. H. A. Beach." The Musical Quarterly 26, No. 3 (1940): 297 310. www.jstor.org/stable/738767.

Miles, Marmaduke Sidney. "The Solo Piano Works of Mrs. H.H.A. Beach.” DMA diss., Peabody Conservatory of Music, 1985.

Valdivia, Hector. "Amy Beach (1867-1944)." In Women Composers: Music Through the Ages, Volume 8, edited by Sylvia Glickman and Martha Furman Schleifer, 369 - 395. MI: Thomson Corporation, 1996. 